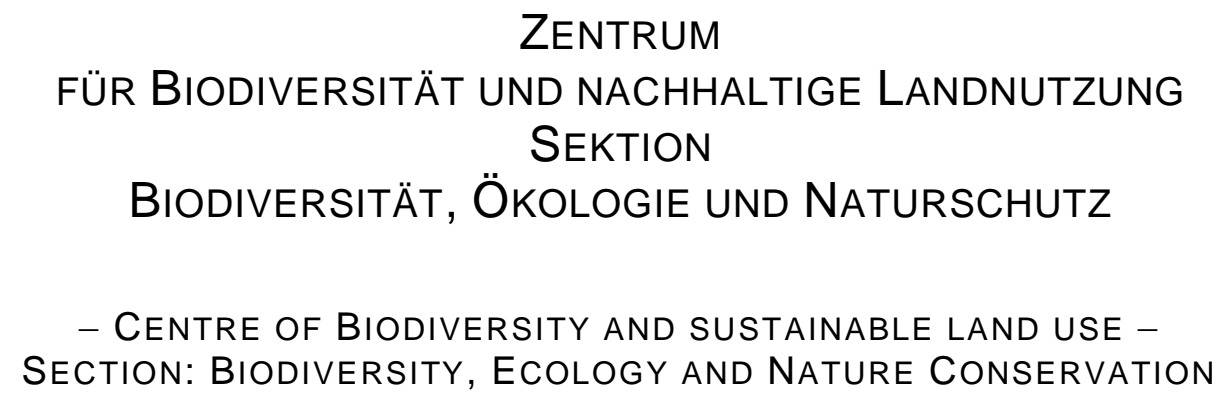

ZENTRUM

FÜR BIODIVERSITÄT UND NACHHALTIGE LANDNUTZUNG

SEKTION

BIOdIVERSITÄT, ÖKOLOGIE UNd NATURSCHUTZ

- Centre of Biodiversity AND Sustainable LAND USE -

SECTION: BIOdIVERSITY, ECOLOGY AND NATURE CONSERVATION

\title{
Trophic structure of soil animal food webs of deciduous forests as analyzed by stable isotope labeling
}

\author{
Dissertation zur Erlangung des Doktorgrades der \\ Mathematisch-Naturwissenschaftlichen Fakultäten der \\ Georg-August-Universität Göttingen
}

\author{
vorgelegt von \\ Diplom Biologin \\ Sarah Lorain Janice Zieger \\ geboren in \\ Paramaribo (Suriname)
}


Referentin/Referent:

Korreferentin/Korreferent:

Tag der mündlichen Prüfung:
Prof. Dr. Stefan Scheu

Prof. Dr. Mark Maraun

22.01.2016 
Jedes gelöste Problem kriegt sofort Junge.

(Konrad Lorenz) 


\section{CONTENTS}

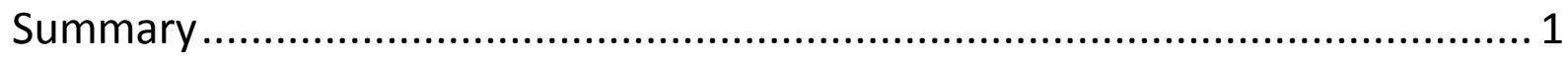

\section{ChAPTER 1}

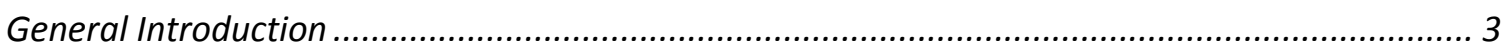

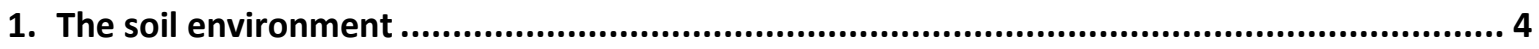

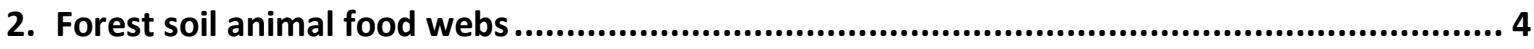

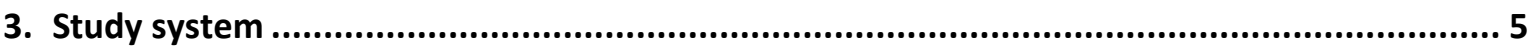

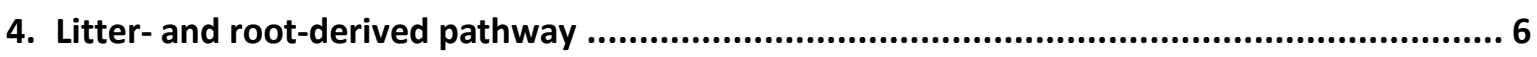

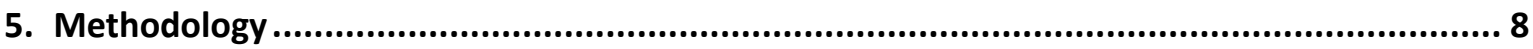

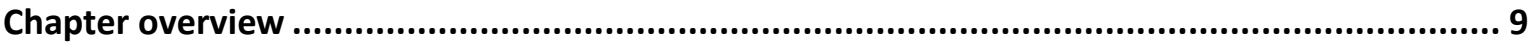

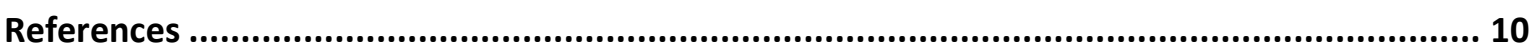

\section{CHAPTER 2}

Incorporation of carbon and nitrogen from leaf litter differing in structural compounds into soil

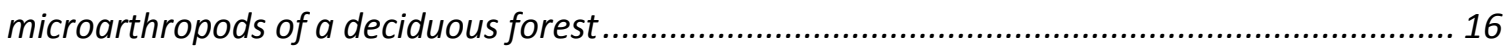

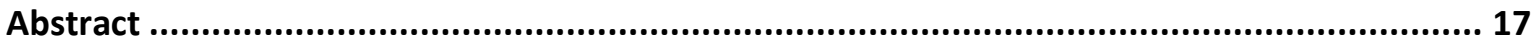

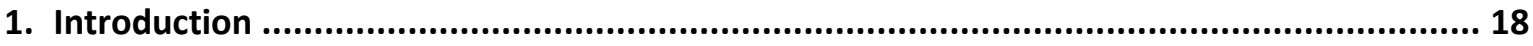

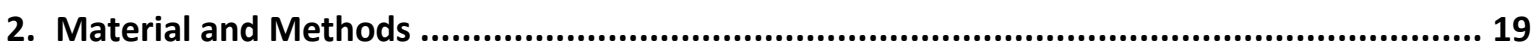

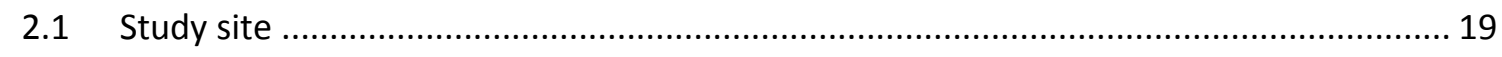

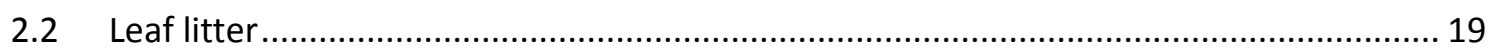

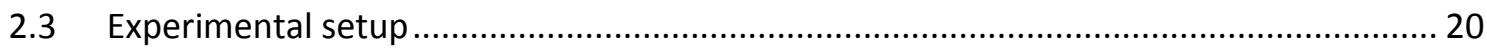

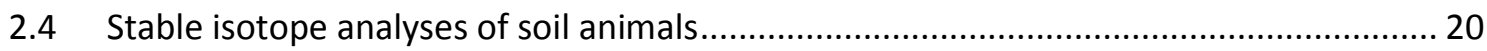

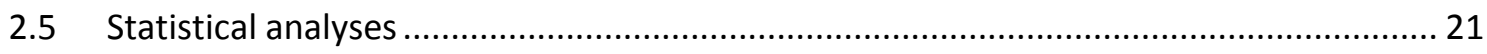

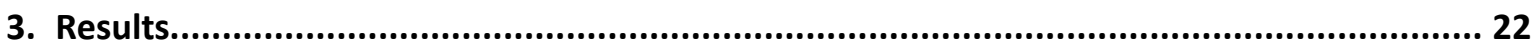

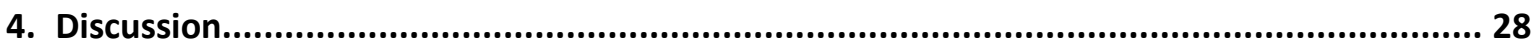

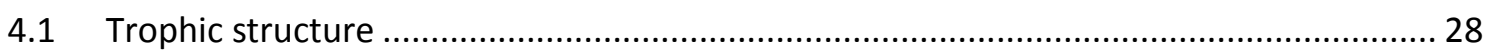

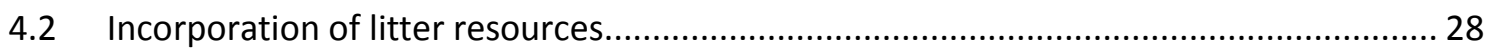

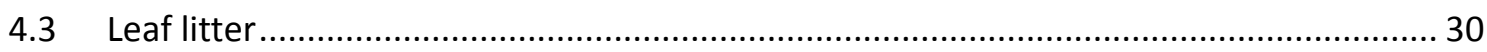

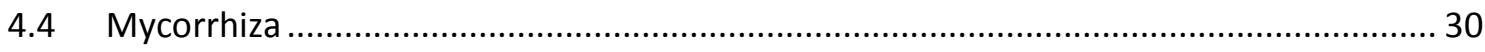

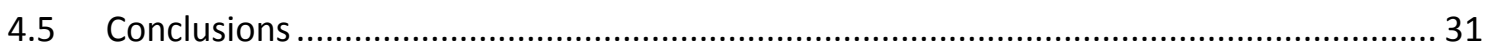

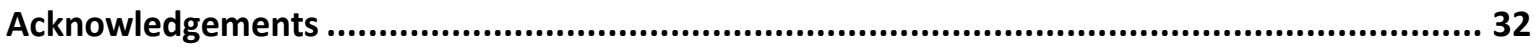

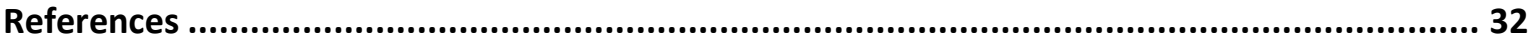




\section{CHAPTER 3}

Beech trees fuel soil animal food webs via root-derived nitrogen ............................................. 36

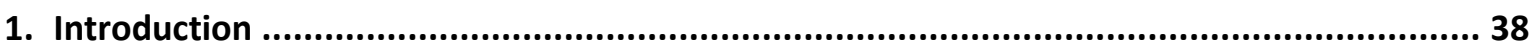

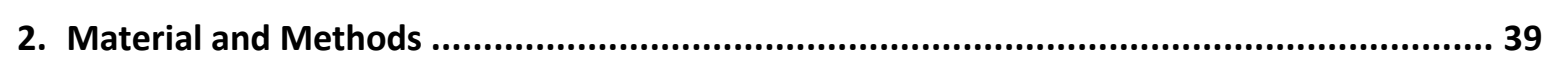

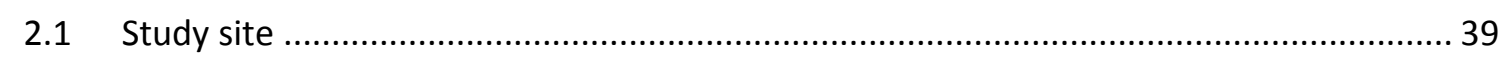

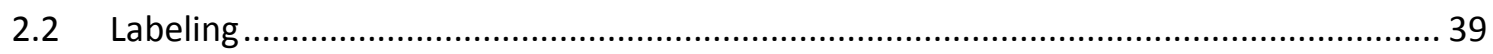

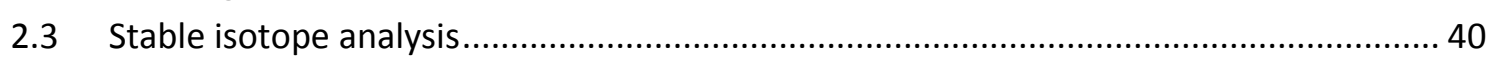

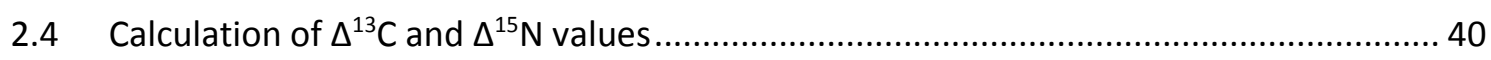

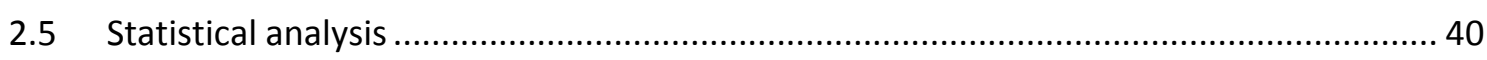

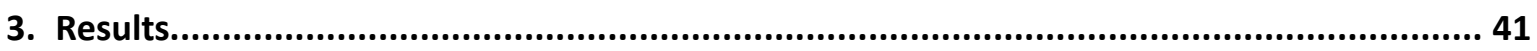

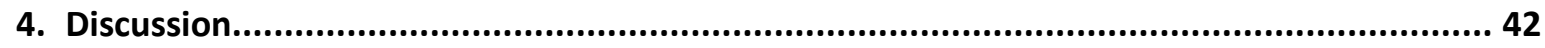

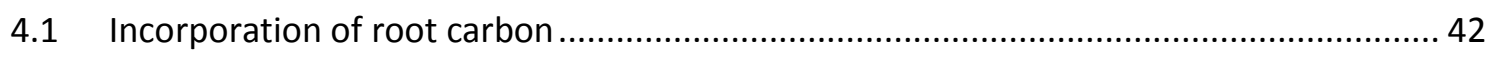

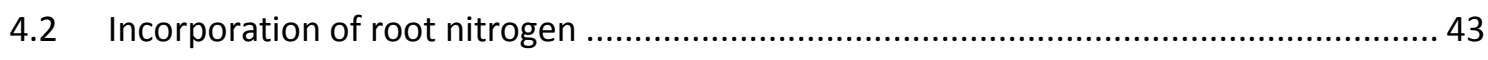

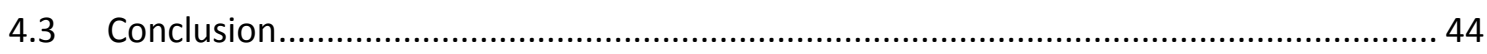

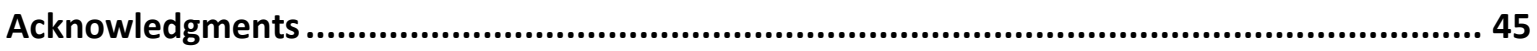

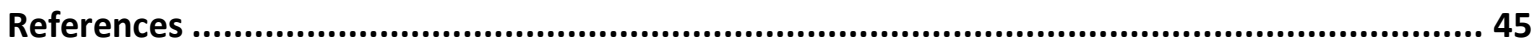

\section{ChAPTER 4}

Root-derived carbon and nitrogen from beech and ash trees differentially fuel soil animal food

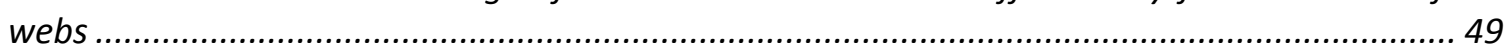

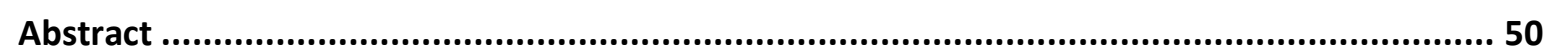

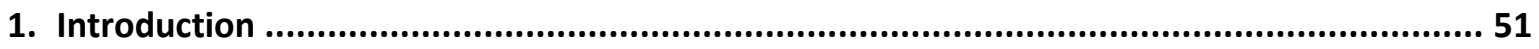

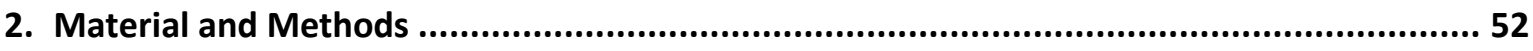

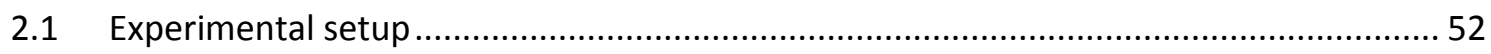

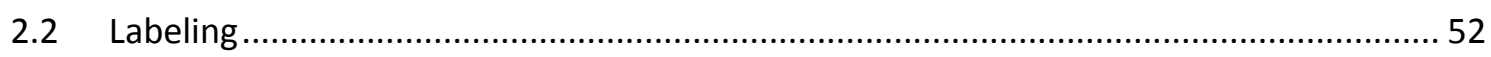

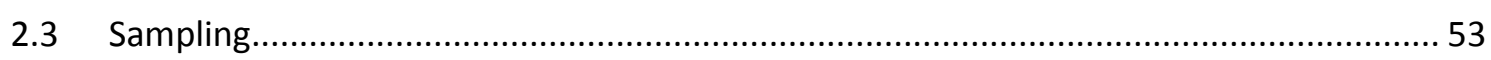

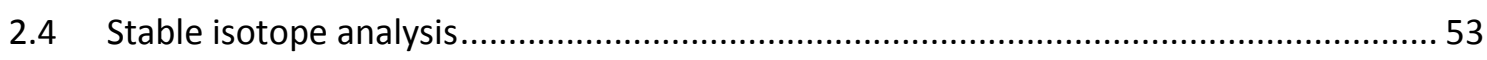

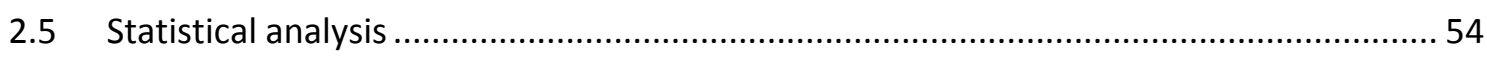

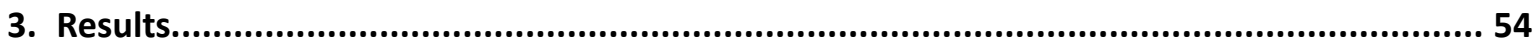

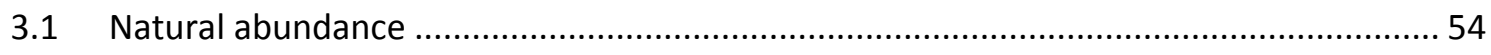

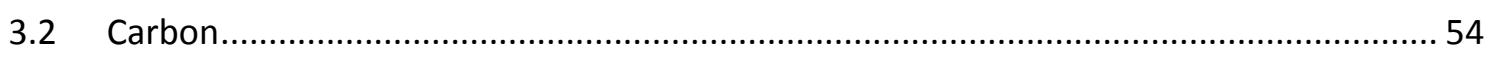

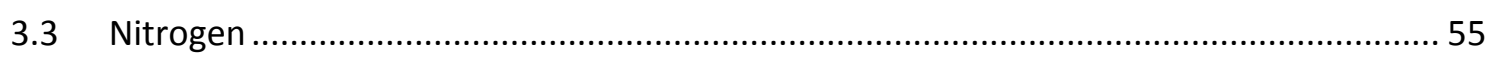

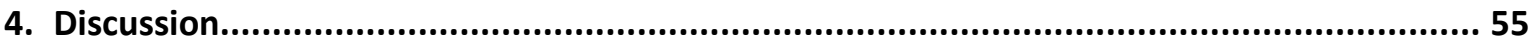

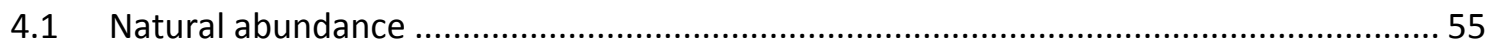

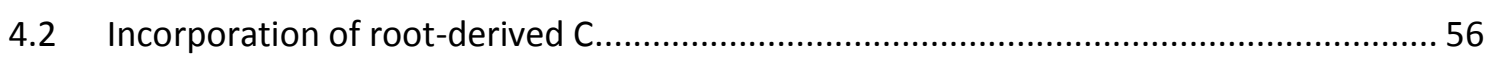

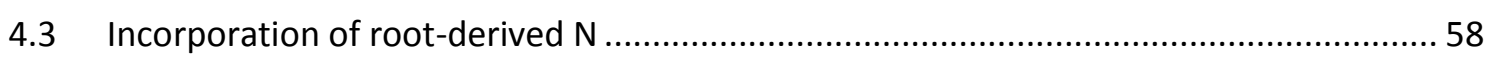

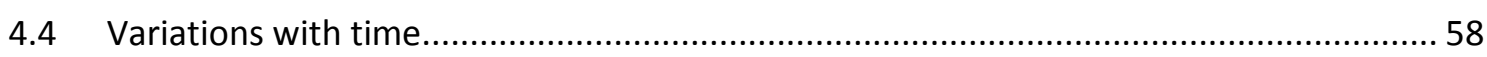

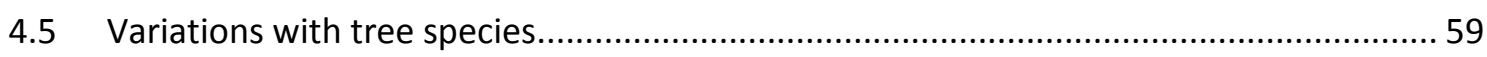

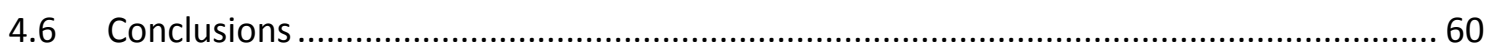

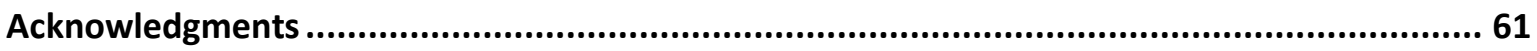

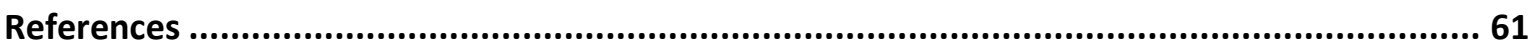

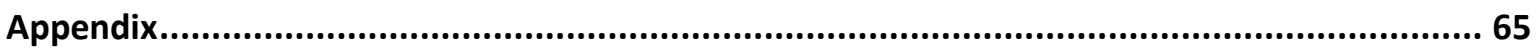




\section{CHAPTER 5}

Experimental evidence that Protura selectively feed on ectomycorrhizal fungi .......................... 70

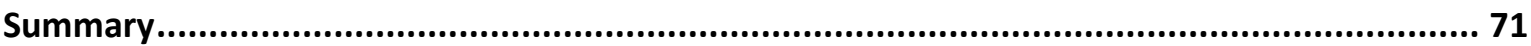

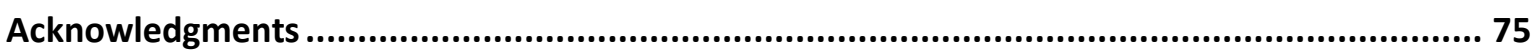

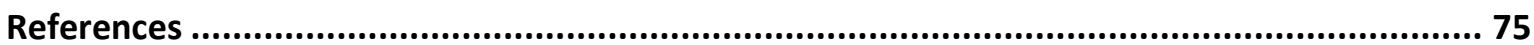

\section{CHAPTER 6}

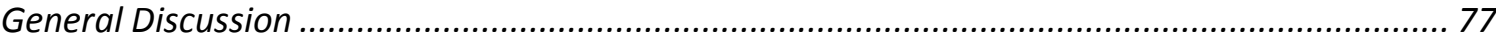

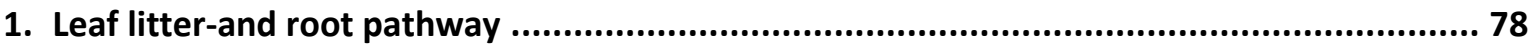

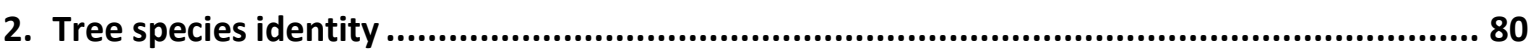

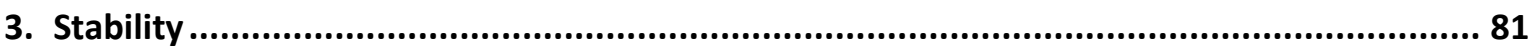

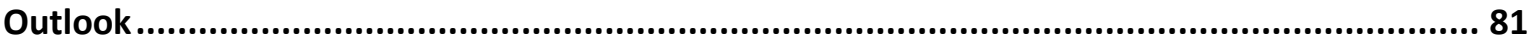

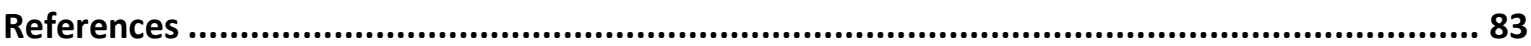

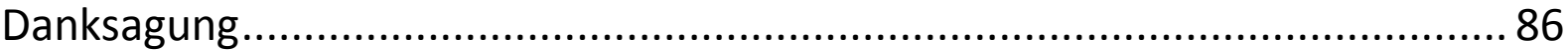

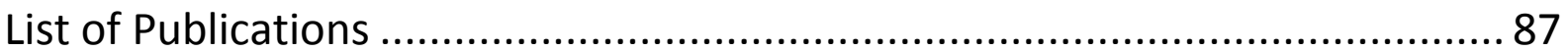

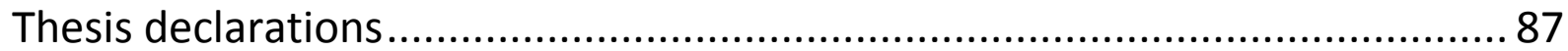




\section{SUMMARY}

Forest soil invertebrates are extremely diverse and form complex food webs. Trophic interactions are concealed from direct observation by the heterogeneous soil system and small size of soil invertebrates and their basal resources such as soil microorganisms. The soil system is connected to plant via roots and leaf litter. Tree species identity is known to affect soil animal communities and energy fluxes. To analyze energy fluxes from the above- to the belowground system stable isotopes are widely used. By using ${ }^{13} \mathrm{C}$ (carbon) and ${ }^{15} \mathrm{~N}$ (nitrogen) labeling experiments, I analyzed the contribution of litter- and root-derived resources to soil animal nutrition. European beech (Fagus sylvatica) and common ash (Fraxinus excelsior), two common tree species of the temperate zone, largely differing in traits such as litter quality and mycorrhizal association, were chosen.

In Chapter 2 the incorporation of litter-derived resources into soil mites was investigated by using beech and ash leaf litter enriched in ${ }^{13} \mathrm{C}$ and ${ }^{15} \mathrm{~N}$. The two leaf litter species differed in structural compounds with beech leaf litter being high in structural compounds and ash leaf litter being low in structural compounds. Soil mites generally incorporated low amounts of litter-derived $\mathrm{C}$ and $\mathrm{N}$, but the incorporation of ash litter $\mathrm{C}$ and $\mathrm{N}$ exceeded that of beech litter $\mathrm{C}$ and $\mathrm{N}$. This was also shown by preference for ash litter by Platynothrus peltifer (Oribatida). Further, soil mite species adapted to deprivation of fast decomposing ash litter by switching diet towards beech litter.

The low contribution of litter-derived resources reinforces the current view, that root-derived resources outweigh litter-derived resources in nourishing soil food webs. Two additional labeling experiments (Chapter 3 and 4) were conducted to investigate the contribution of root-derived resources. By applying $\mathrm{CO}_{2}$ enriched in ${ }^{13} \mathrm{C}$ and immersing leaves in a ${ }^{15} \mathrm{~N}$ containing solution aboveground plant parts were labeled and $\mathrm{C}$ and $\mathrm{N}$ fluxes into soil animals were analyzed. In a field experiment (Chapter 3 ) soil animals incorporated root-derived $\mathrm{N}$ and the incorporation in the beech rhizosphere exceeded that in the ash rhizosphere. A second pulse labeling experiment under controlled conditions in a plant growth chamber confirmed these results. Root-derived $\mathrm{N}$ was transferred into soil animal food webs in a species specific way. Some soil animals such as Onychiuridae (Collembola) incorporated high amounts of ${ }^{15} \mathrm{~N}$ indicating that they directly fed on roots or root hairs, while the predatory mite Veigaia nemorensis (Gamasina) mainly got access to root-derived $\mathrm{N}$ via feeding on secondary decomposers such as Collembola. The distribution of rootderived $\mathrm{N}$ in soil animal food webs may have important ecological consequences. By releasing amino acids plant roots could stimulate microbes and thereby soil animals which are then responsible for decomposition processes. Root-derived C was also incorporated into soil animal food webs and the incorporation into soil animals in the beech rhizosphere exceeded that in the ash rhizosphere presumably mediated by the different association with mycorrhiza. Beech is 
associated with ectomycorrhizal fungi (EMF), while ash is associated with arbuscular mycorrhizal fungi (AMF). In the last study (Chapter 5 ) the analysis of root-derived $C$ and $N$ combined with fatty acid analysis documented that the Protura species Acerentomon sp. is sucking on EMF.

The results of this thesis indicate that energy fluxes in the food web of beech and ash forests differ markedly. Beech trees produce leaf litter not easily to digest, but release root-derived resources into the rhizosphere which are then incorporated into the soil animal food web. In contrast, ash has easier digestible leaf litter, but the incorporation of root-derived resources are less pronounced as compared to beech. Fast decomposition of ash litter within the first year of litter decay might hamper the positive effect of easily ingestible leaf litter and leads to deprivation of food and habitat later in the year. As this thesis investigated the contribution of litter- and rootderived resources in separate experiments further experiments are needed in which both litterand root-derived resources are manipulated simultaneously to quantify the contribution of both pathways in fueling soil animal food webs. 
ChAPTER 1

General Introduction

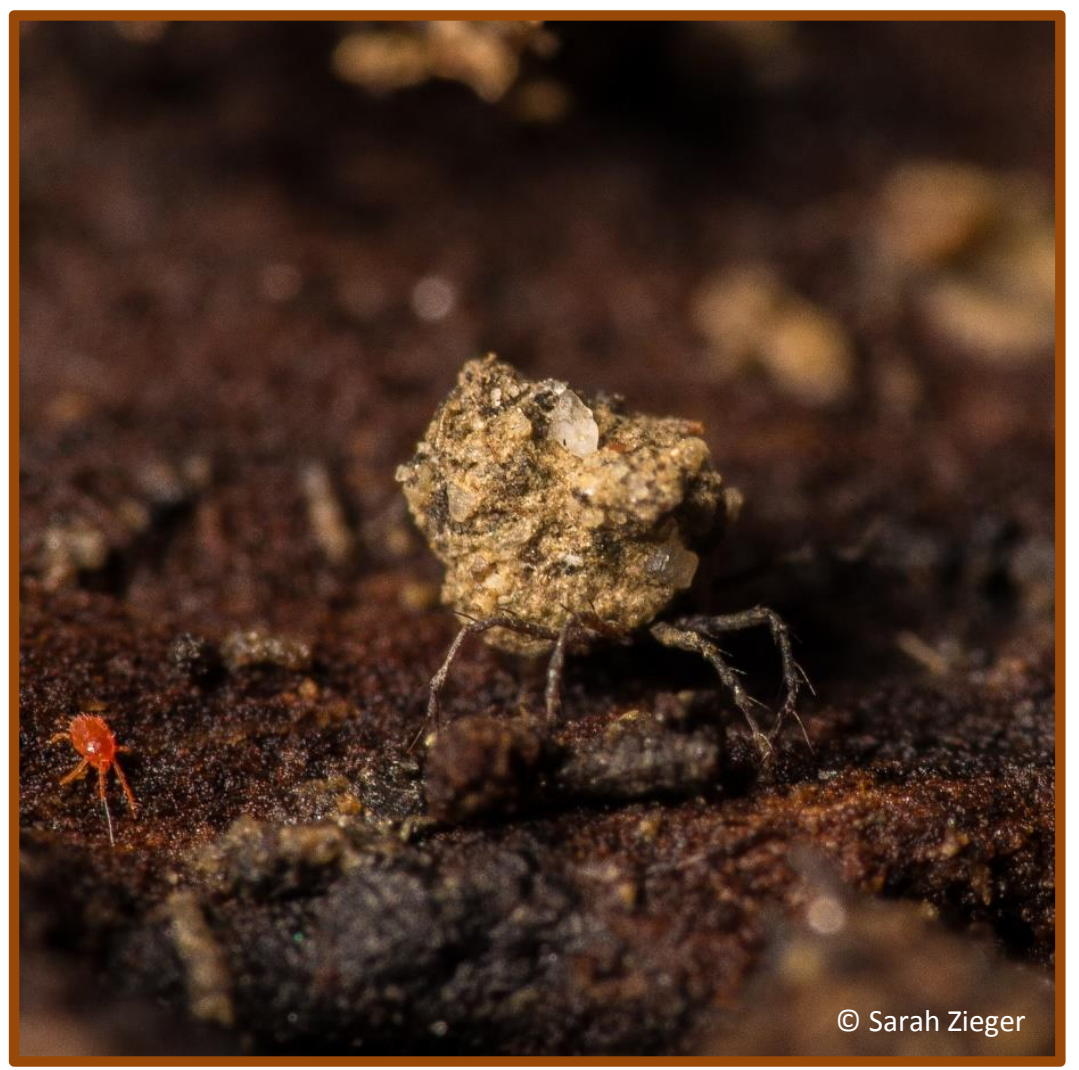




\section{The soil environment}

Soil is a complex system which provides ecosystem services for human wellbeing such as water filtering, serves as substrate for food production as well as for the breakdown of organic materials and nutrient recycling (Dominati et al. 2010). Soil consists of three-phases, water, air and solids, with solids classified into soil organic matter (SOM) and soil mineral matter. This structure forms a physical and chemical microstructure with small-scale heterogeneity resulting in a dynamic habitat for organisms including all major domains of life - Bacteria, Archaea and Eukaryota with representatives of the respective three kingdoms Plantae, Animalia and Fungi.

Traditionally, soil animals are classified according to their body size into microfauna (e.g., Protozoa and Nematoda), mesofauna (e.g., Enchytraeidae, Collembola, Protura, Diplura, Oribatida, Mesostigmata, Astigmata and Prostigmata) and macrofauna (e.g., Lumbricidae, Isopoda, Diplopoda, Chilopoda, Diptera larvae, Coleoptera, Pseudoscorpiones, Opiliones and Araneae) (Swift et al. 1979; Petersen \& Luxton 1982). Soil animal communities have been described to be the most species rich and complex communities in terrestrial ecosystems (Anderson 1975; Giller 1996; Scheu \& Setälä 2002; Crotty et al. 2012) playing important roles in nutrient cycling by interacting with their biotic and abiotic environment (Berg et al. 2001). Species rich taxa such as Collembola and Oribatida can be found in almost all environments including desert and arctic soils (Rusek 1998; Maraun et al. 2007).

\section{Forest soil animal food webs}

Temperate forests are characterized by a strong seasonality caused by alternating temperature and precipitation. This leads to adaptations to climate by plants and animals e.g., allocations of resources and changes in activity. Generally, feeding interactions are of main interest for animal ecologists as diet is one of the essential needs of animals. By these interactions, species are connected across trophic levels and form complex food webs. Species which use similar food resources are aggregated to trophic levels. Generally, organisms can be divided into autotrophs comprising plants, algae and some bacteria, and heterotrophs which are grouped into animals feeding on plants (herbivores) or on animal diets (predators). In soils dead organic matter (detritus) form an important input of energy to the food web thereby serving as the basis of these food webs. Organisms feeding on detritus are termed decomposers and include fungi, bacteria and soil animals.

In temperate deciduous forests soil animal communities are remarkably diverse (Anderson 1975; Schaefer 1991; Scheu 2005) reflected by a broad spectrum of trophic levels. Primary decomposers predominantly feeding on dead organic matter, secondary decomposers mainly feeding on fungi and bacteria, and first, second and third order predators feeding on animals 
(Brussaard et al. 1997; Ponsard \& Arditi 2000; Scheu \& Falca 2000) form complex food webs (Ehnes et al. 2014; Digel et al. 2014).

\section{Study system}

This thesis is part of the Research Training Group 1086 "The Role of Biodiversity for Biogeochemical Cycles and Biotic Interactions in Temperate Deciduous Forests". The sub-project A4 dealt with soil animal communities. In the first phase (2005-2008) of this project effects of tree species diversity on soil animal communities were investigated. Tree species diversity positively affected the density of Lumbricidae, but had no effect on soil macrofauna (Cesarz et al. 2007; Weland 2009). In a consecutive experiment in the second phase (2008-2011) the importance of tree species diversity versus tree species identity was investigated. The results suggested that tree species identity contributed more to the abundance of soil taxa such as Nematoda and Oribatida than tree species diversity (Cesarz et al. 2013b; Eissfeller et al. 2013b). Therefore, the third phase focused on differences in tree species identity.

European temperate deciduous forest are dominated by European beech (Fagus sylvatica L.) interspersed by common ash (Fraxinus excelsior L.), maple (Acer platanoides L., A. pseudoplatanus L.), oak (Quercus robur L., Q. petraea LIEBL.) and elm (UImus glabra HUDS.). In general, tree species influence soil properties (Langenbruch et al. 2012) via litter input or root releases thereby affecting soil microorganisms and, via trophic interactions, these changes propagate to soil animals. This thesis focuses on beech and ash trees as it is known that they are largely different in their functions. Both tree species differ in leaf litter quality e.g., nitrogen (N) concentrations and carbon-to- $\mathrm{N}$ ratio are higher while lignin, $\mathrm{Mn}$ and carbon (C) concentrations are lower in ash than in beech. The higher leaf litter quality of ash results in faster decomposition compared to beech litter (Vesterdal et al. 2008). In addition, forest floor soil respiration and rates of $\mathrm{C}$ turnover are higher under ash as compared to beech, but $\mathrm{C}$ and $\mathrm{N}$ concentrations are higher in forest floors under beech (Vesterdal et al. 2008, 2012). Beech and ash also differ in fine root morphology and fine root chemical traits (Meinen et al. 2009; Beyer et al. 2013) and vary in the release of organic acids with concentrations in the beech rhizosphere exceeding those in the ash rhizosphere (Fender et al. 2013). Beech and ash also differ in the colonization of mycorrhiza with beech being associated with ectomycorrhizal fungi (EMF) while ash being associated with arbuscular mycorrhizal fungi (AMF) (Smith \& Read 1997). Due to these profound differences in physiological properties between both tree species energy fluxes into soil animal communities vary with tree species identity (Cesarz et al. 2013b). 


\section{Litter- and root-derived pathway}

Interactions of the above- and the belowground system are receiving increased attention as they strongly affect C cycling (Bardgett \& Wardle 2010). C bound by aboveground plant organs is decomposed and recycled via the belowground system, i.e. the decomposer food web (Scheu 2005). Soil animal communities are linked with the aboveground system via two pathways, i.e. via leaf litter input and root-derived resources (Wardle 2002).

Leaf litter has been assumed to function as main food resource of soil animals as up to $90 \%$ of net primary plant production is entering the soil as detritus (Cebrian 1999). Leaf litter as food has the advantage that it is not defending itself against consumers as it is dead (Scheu \& Setälä 2002), however, defense mechanisms of living leaves against herbivores such as the production of polyphenols may also affect decomposition processes (Northup et al. 1995; Hättenschwiler \& Vitousek 2000). Despite the lack of defense, leaf litter it is a challenging food resource (Allison 2006) as $\mathrm{N}$ concentrations are low (1-2 \%) as compared to those in animal tissue (ca. $10 \%$ ) (White 1993; Vitousek et al. 2002). Most of litter $C$ is bound in structural compounds and locked up in polymers rich in aliphatic and aromatic compounds (Tan 2014) not readily available for soil animals without help by microorganisms. Bacteria and fungi are strongly involved in decomposing litter as they can access resources from recalcitrant litter compounds via the release of exo-enzymes. Among microorganisms, saprotrophic fungi are specialized in breaking down recalcitrant substances such as cellulose and lignin (De Boer et al. 2005; Osono 2007).

Litter decomposition undergoes a number of steps during which litter $\mathrm{C}$ compounds are modified and mineralized. During this dynamic process the abundance and quality of resources for soil organisms are changing. Due to incorporation into microorganisms and soil animals resources are locked up (Caner et al. 2004; Pollierer et al. 2007) or exit the system via mineralization by the release of gases and leakage of dissolved substances. Litter decomposition is categorized into different phases (Hudson 1968; Berg 2000). The first phase includes rapid mass loss and decline of soluble compounds. This phase is assumed to be driven by initial litter nutrient concentrations. The second phase starts with the degradation of lignin and lignified carbohydrates. The last phase is characterized by a constant lignin level (Berg 2000) with a considerable fraction of litter remaining as recalcitrant material evading further attack by microorganisms (Aber 1990; Prescott et al. 2000).

Soil animals preferentially feed on older decomposed litter (Rihani et al. 1995) with their preference depending on the structure of litter, e.g. tensile strength and palatability (Cornelissen et al. 1999; Perez-Harguindeguy et al. 2000). Soil animals mainly feeding on litter are classified as macrophytophages (Schuster 1956; Luxton 1972) or primary decomposer (Scheu \& Falca 2000; Schneider et al. 2004a). Beside litter, also microorganisms are consumed and serve as important source of animal N (Bradley \& Nichols 1918). Soil animals feeding on microorganisms are classified 
as microphytophages or secondary decomposers (Luxton 1972; Scheu \& Falca 2000). During litter decomposition microbial succession takes place (Torres et al. 2005) which might affect feeding habits of soil animals as palatability of fungi are influenced by the substrate on which the mycelia are growing (Leonard 1984; Klironomos et al. 1992; Kaneko et al. 1995; Kaneda \& Kaneko 2004). Feedback regulations might play a role as soil animals affect litter decomposition by grazing on fungi and bacteria thereby altering competition strength and thus microbial community structure (Hanlon \& Anderson 1979). This may either result in an enhancement or inhibition of litter decomposition (Siepel \& Maaskamp 1994; A'Bear et al. 2010). Also, there is evidence that enzyme activity is affected by grazing, thereby influencing $\mathrm{C}, \mathrm{N}$ and phosphorous cycling (Crowther et al. 2011). Although litter decomposition is an intensively studied field in ecology, studies on the contribution of litter-derived resources to element demands of soil animals are scarce (Caner et al. 2004; Pollierer et al. 2007).

Via their large surface area roots interact with the biotic and abiotic environment by nutrient exchange, stabilization of soil connecting the above- with the belowground system. Recent studies indicate that root-derived resources may be more important in fueling soil animal food webs than those derived from leaf litter (Ruf et al. 2006; Pollierer et al. 2007; Eissfeller et al. 2013a; Gilbert et al. 2014). Root-derived resources include living and dead roots as well as rhizodepositions. Rhizodeposits are substances which are released actively or passively from roots into the soil (Curl \& Truelove 1986; Jones et al. 2009). Rhizodeposits are divided into exudates, leakages, secretions, mucilage, mucigel and lysates (Rovira et al. 1979; Curl \& Truelove 1986) and can be divided into two classes: low molecular weight compounds, such as amino acids, organic acids, sugars, phenolics and other secondary metabolites, and high molecular weight compounds, such as polysaccharides and proteins (Bais et al. 2006). Spatial and temporal excretion patterns of these rhizodeposits lead to hot spots and hot moments in the rhizosphere (Beare et al. 1995; Kuzyakov \& Blagodatskaya 2015). Mutualistic and antagonistic interactions occur between soil microorganisms and plants (Bais et al. 2006; Buée et al. 2009) e.g., via mycorrhiza helper bacteria which can positively affect the mycorrhization of root tips (Fitter \& Garbaye 1994; Frey-Klett et al. 2007), thereby affecting C and nutrient concentrations of plants. The highly active rhizosphere provides food for various soil organisms such as bacteria, fungi and protists which acquire resources from root deposits (Pollierer et al. 2007). Soil animals such as Oribatida also interact with plant roots e.g., via feeding on mycorrhiza (Schneider et al. 2005). Besides roots, also mycorrhizal fungi release substantial amounts of $\mathrm{C}$ into the rhizosphere with the $\mathrm{C}$ fluxes differing between EMF and AMF (Phillips \& Fahey 2005,2006$)$. These differences possibly also propagate to the adjacent soil animal food web. 


\section{Methodology}

The reason for lack of knowledge on soil animal feeding relationships is the opaqueness of the soil habitat making direct observations difficult or impossible. Facing these difficulties a number of methods have been developed to understand feeding interactions of soil animals such as visual gut content analysis (Schuster 1956; Anderson \& Healey 1972; Luxton 1972) and enzyme activity in the gut (Siepel \& de Ruiter-Dukman 1993; Berg et al. 2004). The disadvantage of these methods is, that inspecting the gut content does not allow to differentiate between ingestion and digestion. Further, enzyme activity in the gut lack information on the origin of the enzymes as at least in part they may be produced by microorganisms ingested with the food material (Schneider et al. 2004b).

Fifteen years ago the natural abundance of the stable isotope ${ }^{15} \mathrm{~N}$ was used for the first time to identify trophic groups in soil food webs of forest ecosystems (Ponsard \& Arditi 2000; Scheu \& Falca 2000). The technology allows ascribing species to trophic levels as ${ }^{15} \mathrm{~N}$ concentrations increase by $3.4 \%$ per trophic level due to fractionation processes. Enzymes involved in excretion of $\mathrm{N}$ release excrements depleted in ${ }^{15} \mathrm{~N}$ (Minagawa \& Wada 1984; Peterson \& Fry 1987; Post 2002; Mill et al. 2007). Since the early studies, the method has been heavily used to identify trophic positions within Oribatida (Schneider et al. 2004a; Maraun et al. 2011), Collembola (Chahartaghi et al. 2005), Mesostigmata (Klarner et al. 2013) and Nematoda (Kudrin et al. 2015). As natural abundance signatures of stable isotopes do not allow to identify trophic links other technologies have been adopted such as neutral lipid fatty acid (NLFA) analysis (Ruess et al. 2005; Ruess \& Chamberlain 2010). Via dietary routing fatty acids can be traced from the basal resource at least through three trophic levels (Pollierer et al. 2010).

In addition to analyzing the trophic structure of food webs, stable isotope analysis also can be used to trace element flows in ecosystems (Pollierer et al. 2007; Högberg et al. 2008; Eissfeller et al. 2013a). By continuously adding stable isotope compounds to a system the distribution and pool sizes of system compartments can be identified by measuring isotope ratios. The change in isotope ratios are due to tissue turnover, transformation, translocation or leakage/effusion processes in the system. In contrast, adding a pulse of stable isotope compounds for a short period of time allows to investigate tissue turnover and pathways of substances in different system compartments. Therefore, long term and pulse labeling experiments are a promising tool to investigate energy fluxes in food webs and to identify the contribution of litter- and root-derived resources to animal nutrition (Ruf et al. 2006; Pollierer et al. 2007; Crotty et al. 2012; Eissfeller et al. 2013a; Brose \& Scheu 2014). 


\section{Chapter overview}

In this thesis effects of tree species identity on soil animal food webs were investigated by using stable isotope labeling experiments. In Chapter 2 the energy and nutrient flux of decomposing leaf litter into soil mites were investigated by using ${ }^{13} \mathrm{C}$ and ${ }^{15} \mathrm{~N}$ enriched leaf litter of beech and ash differing in structural compounds, but with similar N concentration. In Chapter 3 the influence of root-derived $\mathrm{C}$ and $\mathrm{N}$ were investigated in a field experiment as the contribution of root-derived $\mathrm{N}$ to soil animal food webs has not yet been tested. A shortcoming of this study was the difficulty to identify the $\mathrm{C}$ flux in the field, therefore, in Chapter 4 the flux of both $\mathrm{C}$ and $\mathrm{N}$ from plants into the soil animal food web was investigated under controlled condition in the laboratory. In Chapter 5 feeding behavior of Protura was investigated by using the experiment described in Chapter 4 and adding information on neutral fatty acid composition.

We examined the following main hypotheses:

(1) The use of litter $\mathrm{C}$ and $\mathrm{N}$ depends on the amount of structural compounds in the litter with litter low in structural compounds being more important for the nutrition of soil animals. In addition, due to differences in palatability, litter low in structural compounds is preferred by soil animals (Chapter 2).

(2) Incorporation of root-derived C into soil animal taxa varies with tree species associated with either EMF (beech) or AMF (ash), with the incorporation in EMF beech exceeding that in AMF ash (Chapter 3+4)

(3) Incorporation of root-derived $\mathrm{N}$ is of minor importance for soil animal nutrition and therefore, incorporation into the soil animal food web varies little with tree species associated with either EMF (beech) or AMF (ash) (Chapter 3+4)

(4) Acerentomon sp. (Protura) quickly incorporates recently assimilated plant C, but not plant N, via sucking on mycorrhizal hyphae (Chapter 5). 


\section{References}

A'Bear, A.D., Boddy, L. \& Raspotnig, G. (2010) Non-trophic effects of oribatid mites on cord-forming basidiomycetes in soil microcosms. Ecological Entomology, 35, 477-484.

Aber, J. (1990) Predicting long-term patterns of mass loss, nitrogen dynamics, and soil organic matter formation from initial fine litter chemistry in temperate forest ecosystems. Canadian Journal of Botany, 68, 2201-2208.

Allison, S.D. (2006) Brown ground: a soil carbon analogue for the green world hypothesis? The American Naturalist, 167, 619-627.

Anderson, J.M. (1975) The enigma of soil animal diversity. Progress in Soil Zoology Proceedings of the Fifth International Colloquium of Soil Zoology (ed J. Vaněk), pp. 51-58. Academia, Prague.

Anderson, J.M. \& Healey, I.N. (1972) Seasonal and Inter-Specific Variation in Major Components of the Gut Contents of Some Woodland Collembola. Journal of Animal Ecology, 41, 359-368.

Bais, H.P., Weir, T.L., Perry, L.G., Gilroy, S. \& Vivanco, J.M. (2006) The role of root exudates in rhizosphere interactions with plants and other organisms. Annual Review of Plant Biology, 57, 233-266.

Bardgett, R.D. \& Wardle, D.A. (2010) Aboveground- Belowground Linkages. Biotic Interactions, Ecosystem Processes, and Global Change. Oxford University Press.

Beare, M.H., Coleman, D.C., Crossley, D.A., Hendrix, P.F. \& Odum, E.P. (1995) A hierarchical approach to evaluating the significance of soil biodiversity to biogeochemical cycling. Plant and Soil, 170, 5-22.

Berg, B. (2000) Litter decomposition and organic matter turnover in northern forest soils. Forest Ecology and Management, 133, 13-22.

Berg, M.P., de Ruiter, P.C., Didden, W., Janssen, M., Schouten, T. \& Verhoef, H. (2001) Community food web, decomposition and nitrogen mineralisation in a stratified Scots pine forest soil. Oikos, 94, 130-142.

Berg, M.P., Stoffer, M. \& Van Den Heuvel, H.H. (2004) Feeding guilds in Collembola based on digestive enzymes. Pedobiologia, 48, 589-601.

Beyer, F., Hertel, D. \& Leuschner, C. (2013) Fine root morphological and functional traits in Fagus sylvatica and Fraxinus excelsior saplings as dependent on species, root order and competition. Plant and Soil, 373, 143-156.

De Boer, W., Folman, L.B., Summerbell, R.C. \& Boddy, L. (2005) Living in a fungal world: Impact of fungi on soil bacterial niche development. FEMS Microbiology Reviews, 29, 795-811.

Bradley, H.C. \& Nichols, M.S. (1918) Nitrogen content of bacterial cells. Journal of Biological Chemistry, 33, 526-529.

Brose, U. \& Scheu, S. (2014) Into darkness: unravelling the structure of soil food webs. Oikos, 123, $1153-1156$.

Brussaard, L., Behan-Pelletier, V.M., Bignell, D.E., Brown, V.K., Didden, W., Folgarait, P., Fragoso, C., Freckman, D.W., Gupta, V., Hattori, T., Hawksworth, D.L., Klopatek, C., Lavelle, P., Malloch, D.W., Rusek, J., Soderstrom, B., Tiedje, J.M. \& Virginia, R.A. (1997) Biodiversity and ecosystem functioning in soil. Ambio, 26, 563-570.

Buée, M., Boer, W., Martin, F., Overbeek, L. \& Jurkevitch, E. (2009) The rhizosphere zoo: An overview of plant-associated communities of microorganisms, including phages, bacteria, archaea, and fungi, and of some of their structuring factors. Plant and Soil, 321, 189-212. 
Caner, L., Zeller, B., Dambrine, E., Ponge, J.-F., Chauvat, M. \& Llanque, C. (2004) Origin of the nitrogen assimilated by soil fauna living in decomposing beech litter. Soil Biology \& Biochemistry, 36, 1861-1872.

Cebrian, J. (1999) Patterns in the fate of production in plant communities. The American Naturalist, 154, 449-468.

Cesarz, S., Fahrenholz, N., Migge-Kleian, S., Platner, C. \& Schaefer, M. (2007) Earthworm communities in relation to tree diversity in a deciduous forest. European Journal of Soil Biology, 43, S61-S67.

Cesarz, S., Ruess, L.R., Jacob, M., Jacob, A., Schaefer, M. \& Scheu, S. (2013) Tree species diversity versus tree species identity: Driving forces in structuring forest food webs as indicated by soil nematodes. Soil Biology \& Biochemistry, 62, 36-45.

Chahartaghi, M., Langel, R., Scheu, S. \& Ruess, L.R. (2005) Feeding guilds in Collembola based on nitrogen stable isotope ratios. Soil Biology \& Biochemistry, 37, 1718-1725.

Cornelissen, J.H.C., Perez-Harguindeguy, N., Diaz, S., Grime, J.P., Marzano, B., Cabido, M., Vendramini, F. \& Cerabolini, B. (1999) Leaf structure and defence control litter decomposition rate across species and life forms in regional floras on two continents. New Phytologist, 143, 191-200.

Crotty, F. V., Adl, S.M., Blackshaw, R.P. \& Murray, P.J. (2012) Using Stable Isotopes to Differentiate Trophic Feeding Channels within Soil Food Webs. The Journal of Eukaryotic Microbiology, 59, 520-526.

Crowther, T.W., Jones, T.H., Boddy, L. \& Baldrian, P. (2011) Invertebrate grazing determines enzyme production by basidiomycete fungi. Soil Biology \& Biochemistry, 43, 2060-2068.

Curl, E.A. \& Truelove, B. (1986) The Rhizosphere. Springer-Verlag, Berlin/Heidelberg.

Digel, C., Curtsdotter, A., Riede, J., Klarner, B. \& Brose, U. (2014) Unravelling the complex structure of forest soil food webs: Higher omnivory and more trophic levels. Oikos, 123, 1157-1172.

Dominati, E., Patterson, M. \& Mackay, A. (2010) A framework for classifying and quantifying the natural capital and ecosystem services of soils. Ecological Economics, 69, 1858-1868.

Ehnes, R.B., Pollierer, M.M., Erdmann, G., Klarner, B., Eitzinger, B., Digel, C., Ott, D., Maraun, M., Scheu, S. \& Brose, U. (2014) Lack of energetic equivalence in forest soil invertebrates. Ecology, 95, 527-537.

Eissfeller, V., Beyer, F., Valtanen, K., Hertel, D., Maraun, M., Polle, A. \& Scheu, S. (2013a) Incorporation of plant carbon and microbial nitrogen into the rhizosphere food web of beech and ash. Soil Biology \& Biochemistry, 62, 76-81.

Eissfeller, V., Langenbruch, C., Jacob, A., Maraun, M. \& Scheu, S. (2013b) Tree identity surpasses tree diversity in affecting the community structure of oribatid mites (Oribatida) of deciduous temperate forests. Soil Biology \& Biochemistry, 63, 154-162.

Fender, A.C., Gansert, D., Jungkunst, H.F., Fiedler, S., Beyer, F., Schützenmeister, K., Thiele, B., Valtanen, K., Polle, A. \& Leuschner, C. (2013) Root-induced tree species effects on the source/sink strength for greenhouse gases $(\mathrm{CH} 4, \mathrm{~N} 2 \mathrm{O}$ and $\mathrm{CO} 2)$ of a temperate deciduous forest soil. Soil Biology \& Biochemistry, 57, 587-597.

Fitter, A. \& Garbaye, J. (1994) Interactions between mycorrhizal fungi and other soil organisms. Plant and Soil, 159, 123-132.

Frey-Klett, P., Garbaye, J. \& Tarkka, M. (2007) The mycorrhiza helper bacteria revisited. New Phytologist, 176, 22-36. 
Gilbert, K.J., Fahey, T.J., Maerz, J.C., Sherman, R.E., Bohlen, P., Dombroskie, J.J., Groffman, P.M. \& Yavitt, J.B. (2014) Exploring carbon flow through the root channel in a temperate forest soil food web. Soil Biology \& Biochemistry, 76, 45-52.

Giller, P.S. (1996) The diversity of soil communities, the 'poor man's tropical rainforest'. Biodiversity and Conservation, 5, 135-168.

Hanlon, R.D.G. \& Anderson, J.M. (1979) The effects of collembola grazing on microbial activity in decomposing leaf litter. Oecologia, 38, 93-99.

Hättenschwiler, S. \& Vitousek, P.M. (2000) The role of polyphenols in terrestrial ecosystem nutrient cycling. Trends in Ecology and Evolution, 15, 238-242.

Högberg, P., Högberg, M.N., Göttlicher, S.G., Betson, N.R., Keel, S.G., Metcalfe, D.B., Campbell, C.D., Schindlbacher, A., Hurry, V., Lundmark, T., Linder, S. \& Näsholm, T. (2008) High temporal resolution tracing of photosynthate carbon from the tree canopy to forest soil microorganisms. New Phytologist, 177, 220-228.

Hudson, H. (1968) The ecology of fungi on plant remains above the soil. New Phytologist, 67, 837874.

Jones, D.L., Nguyen, C. \& Finlay, R.D. (2009) Carbon flow in the rhizosphere: Carbon trading at the soil-root interface. Plant and Soil, 321, 5-33.

Kaneda, S. \& Kaneko, N. (2004) The feeding preference of a collembolan (Folsomia candida Willem) on ectomycorrhiza (Pisolithus tinctorius (Pers.)) varies with mycelial growth condition and vitality. Applied Soil Ecology, 27, 1-5.

Kaneko, N., McLean, M.A. \& Parkinson, D. (1995) Grazing preference of Onychiurus subtenuis (Collembola) and Oppiella nova (Oribatei) for fungal species inoculated on pine needles. Pedobiologia, 39, 538-546.

Klarner, B., Maraun, M. \& Scheu, S. (2013) Trophic diversity and niche partitioning in a species rich predator guild - Natural variations in stable isotope ratios $(13 \mathrm{C} / 12 \mathrm{C}, 15 \mathrm{~N} / 14 \mathrm{~N})$ of mesostigmatid mites (Acari, Mesostigmata) from Central European beech forests. Soil Biology \& Biochemistry, 57, 327-333.

Klironomos, J.N., Widden, P. \& Deslandes, I. (1992) Feeding preferences of the collembolan Folsomia candida in relation to microfungal successions on decaying litter. Soil Biology \& Biochemistry, 24, 685-692.

Kudrin, A.A., Tsurikov, S.M. \& Tiunov, A. V. (2015) Trophic position of microbivorous and predatory soil nematodes in a boreal forest as indicated by stable isotope analysis. Soil Biology and Biochemistry, 86, 193-200.

Kuzyakov, Y. \& Blagodatskaya, E. (2015) Microbial hotspots and hot moments in soil: Concept \& review. Soil Biology and Biochemistry, 83, 184-199.

Langenbruch, C., Helfrich, M. \& Flessa, H. (2012) Effects of beech (Fagus sylvatica), ash (Fraxinus excelsior) and lime (Tilia spec.) on soil chemical properties in a mixed deciduous forest. Plant and Soil, 352, 389-403.

Leonard, M.A. (1984) Observations on the influence of culture conditions on the fungal feeding preferences of Folsomia candida (Collembola: Isotomidae). Pedobiologia, 26, 361-367.

Luxton, M. (1972) Studies on the oribatid mites of a Danish beech wood soil. I. Nutritional biology. Pedobiologia, 12, 434-463. 
Maraun, M., Erdmann, G., Fischer, B.M., Pollierer, M.M., Norton, R.A., Schneider, K. \& Scheu, S. (2011) Stable isotopes revisited: Their use and limits for oribatid mite trophic ecology. Soil Biology \& Biochemistry, 43, 877-882.

Maraun, M., Schatz, H. \& Scheu, S. (2007) Awesome or ordinary? Global diversity patterns of oribatid mites. Ecography, 30, 209-216.

Meinen, C., Hertel, D. \& Leuschner, C. (2009) Biomass and morphology of fine roots in temperate broad-leaved forests differing in tree species diversity: is there evidence of below-ground overyielding? Oecologia, 161, 99-111.

Mill, A.C., Pinnegar, J.K. \& Polunin, N.V.C. (2007) Explaining isotope trophic-step fractionation: why herbivorous fish are different. Functional Ecology, 21, 1137-1145.

Minagawa, M. \& Wada, E. (1984) Stepwise enrichment of $15 \mathrm{~N}$ along food chains: Further evidence and the relation between $\delta 15 \mathrm{~N}$ and animal age. Geochimica et Cosmochimica Acta, 48, 11351140 .

Northup, R.R., Yu, Z., Dahlgren, R., A. \& Vogt, K. (1995) Polyphenol control of nitrogen release from pine litter. Nature, 377, 227-229.

Osono, T. (2007) Ecology of ligninolytic fungi associated with leaf litter decomposition. Ecological Research, 22, 955-974.

Perez-Harguindeguy, N., Diaz, S., Cornelissen, J.H.C., Vendramini, F., Cabido, M. \& Castellanos, A. (2000) Chemistry and toughness predict leaf litter decomposition rates over a wide spectrum of functional types and taxa in central Argentina. Plant and Soil, 218, 21-30.

Petersen, H. \& Luxton, M. (1982) A comparative analysis of soil fauna populations and their role in decomposition processes. Oikos, 39, 288-388.

Peterson, B.J. \& Fry, B. (1987) Stable isotopes in ecosystem studies. Annual Review of Ecology, Evolution, and Systematics, 18, 293-320.

Pollierer, M.M., Langel, R., Körner, C., Maraun, M. \& Scheu, S. (2007) The underestimated importance of belowground carbon input for forest soil animal food webs. Ecology Letters, 10, 729-736.

Pollierer, M.M., Scheu, S. \& Haubert, D. (2010) Taking it to the next level: Trophic transfer of marker fatty acids from basal resource to predators. Soil Biology \& Biochemistry, 42, 919-925.

Ponsard, S. \& Arditi, R. (2000) What can stable isotopes ( $\delta 15 \mathrm{~N}$ and $\delta 13 \mathrm{C}$ ) tell about the food web of soil macro-invertebrates? Ecology, 81, 852-864.

Post, D.M. (2002) Using stable isotopes to estimate trophic position: models, methods, and assumptions. Ecology, 83, 703-718.

Prescott, C.E., Zabek, L.M., Staley, C.L. \& Kabzems, R. (2000) Decomposition of broadleaf and needle litter in forests of British Columbia: influences of litter type, forest type, and litter mixtures. Canadian Journal of Forest Research, 30, 1742-1750.

Rihani, M., Cancela da Fonseca, J.P. \& Kiffer, E. (1995) Decomposition of beech leaf litter by microflora and mesofauna. II. Food preferences and action of oribatid mites on different substrates. European Journal of Soil Biology, 31, 67-79.

Rovira, A.D., Foster, R.C. \& Martin, J.K. (1979) Note on terminology: origin, nature and nomenclature of the organic materials in the rhizosphere. The Soil-Root Interface (ed J.L. Harley), pp. 1-4. Elsevier.

Ruess, L.R. \& Chamberlain, P.M. (2010) The fat that matters: Soil food web analysis using fatty acids and their carbon stable isotope signature. Soil Biology \& Biochemistry, 42, 1898-1910. 
Ruess, L.R., Schütz, K. \& Haubert, D. (2005) Application of lipid analysis to understand trophic interactions in soil. Ecology, 86, 2075-2082.

Ruf, A., Kuzyakov, Y. \& Lopatovskaya, O. (2006) Carbon fluxes in soil food webs of increasing complexity revealed by $14 \mathrm{C}$ labelling and $13 \mathrm{C}$ natural abundance. Soil Biology \& Biochemistry, 38, 2390-2400.

Rusek, J. (1998) Biodiversity of Collembola and their functional role in the ecosystem. Biodiversity \& Conservation, 7, 1207-1219.

Schaefer, M. (1991) The animal community: diversity and resources. Temperate Deciduous Forests (Ecosystems of the World) (eds E. Rohrig \& B. Ulrich), pp. 51-120. Elsevier, Amsterdam.

Scheu, S. (2005) Linkages Between Tree Diversity, Soil Fauna and Ecosystem Processes. Forest Diversity and Function (eds M. Scherer-Lorenzen, C. Körner, \& E.-D. Schulze), pp. 211-233. Springer-Verlag, Berlin/Heidelberg.

Scheu, S. \& Falca, M. (2000) The soil food web of two beech forests (Fagus sylvatica) of contrasting humus type: stable isotope analysis of a macro- and a mesofauna-dominated community. Oecologia, 123, 285-296.

Scheu, S. \& Setälä, H. (2002) Multitrophic interactions in decomposer food-webs. Multitrophic Level Interactions (eds T. Tscharntke \& B.A. Hawkins), pp. 223-264. Cambridge University Press, Cambridge.

Schneider, K., Migge, S., Norton, R.A., Scheu, S., Langel, R., Reineking, A. \& Maraun, M. (2004a) Trophic niche differentiation in soil microarthropods (Oribatida, Acari): evidence from stable isotope ratios (15N/14N). Soil Biology \& Biochemistry, 36, 1769-1774.

Schneider, K., Renker, C. \& Maraun, M. (2005) Oribatid mite (Acari, Oribatida) feeding on ectomycorrhizal fungi. Mycorrhiza, 16, 67-72.

Schneider, K., Renker, C., Scheu, S. \& Maraun, M. (2004b) Feeding biology of oribatid mites: a minireview. Phytophaga, 14, 247-256.

Schuster, R. (1956) Der Anteil der Oribatiden an den Zersetzungsvorgängen im Boden. Zeitschrift für Morphologie und Ökologie der Tiere, 45, 1-33.

Siepel, H. \& Maaskamp, F. (1994) Mites of different feeding guilds affect decomposition of organic matter. Soil Biology \& Biochemistry, 26, 1389-1394.

Siepel, H. \& de Ruiter-Dukman, E.M. (1993) Feedings guilds of oribatid mites based on their carbohydrase activities. Soil Biology \& Biochemistry, 25, 1491-1497.

Smith, S.E. \& Read, D.J. (1997) Mycorrhizal Symbiosis, Second edi. Elsevier.

Swift, M.J., Heal, O.W. \& Anderson, J.M. (1979) Decomposition in Terrestrial Ecosystems. Blackwell Science, Oxford.

Tan, K.H. (2014) Humic Matter in Soil and the Environment: Principles and Controversies, second edi. CRC Press.

Torres, P.A., Abril, A.B. \& Bucher, E.H. (2005) Microbial succession in litter decomposition in the semi-arid Chaco woodland. Soil Biology and Biochemistry, 37, 49-54.

Vesterdal, L., Elberling, B., Christiansen, J.R., Callesen, I. \& Schmidt, I.K. (2012) Soil respiration and rates of soil carbon turnover differ among six common European tree species. Forest Ecology and Management, 264, 185-196. 
Vesterdal, L., Schmidt, I.K., Callesen, I., Nilsson, L.O. \& Gundersen, P. (2008) Carbon and nitrogen in forest floor and mineral soil under six common European tree species. Forest Ecology and Management, 255, 35-48.

Vitousek, P.M., Hättenschwiler, S., Olander, L. \& Allison, S. (2002) Nitrogen and nature. Ambio, 31, 97-101.

Wardle, D.A. (2002) Communities and Ecosystems: Linking the Aboveground and Belowground Components. Princeton University Press, Princeton, NJ.

Weland, N. (2009) Diversität Und Trophische Struktur Der Bodenfauna Und Ihr Einfluss Auf Die Streuzersetzung in Wäldern Mit Zunehmender Baumartendiversität.

White, T.C.R. (1993) The Inadequate Environment: Nitrogen and the Abundance of Animals. Springer, Berlin Heidelberg. 


\section{ChAPTER 2}

\section{Incorporation of carbon and nitrogen from leaf litter differing in structural compounds into soil microarthropods of a deciduous forest}

Sarah L. Zieger, Verena Eissfeller, Mark Maraun, Stefan Scheu

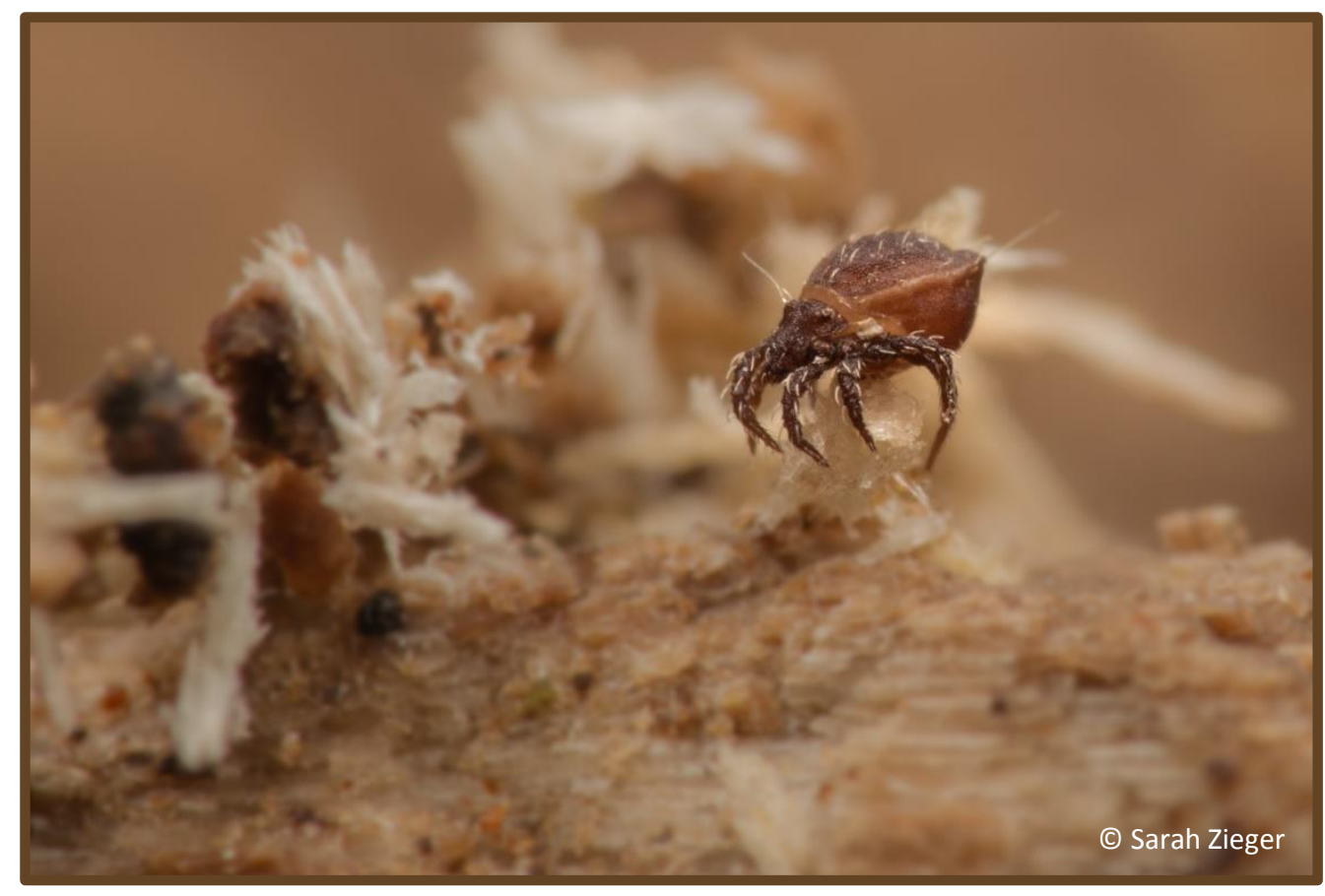

Published in:

Zieger, S.L., Eissfeller, V., Maraun, M. \& Scheu, S. (2015) Incorporation of carbon and nitrogen from leaf litter differing in structural compounds into soil microarthropods of a deciduous forest. Pedobiologia, 58, 219-227. 


\begin{abstract}
Detritivorous soil invertebrates process large quantities of leaf litter material. Focusing on decomposer (Oribatida) and predatory mites (Mesostigmata) we investigated the incorporation of resources from leaf litter rich (European beech, Fagus sylvatica) and poor (European ash, Fraxinus excelsior) in structural compounds using stable isotopes. Using litter mixtures we investigated if soil mites preferentially incorporate carbon $(C)$ and nitrogen $(N)$ derived from beech or ash leaf litter. Using the rotated-core method we established treatments with and without mycorrhiza as interactions between mycorrhiza and saprotrophic microorganisms may alter the availability of litter resources to soil invertebrates. Conform to our expectations primary decomposers incorporated more $\mathrm{C}$ and $\mathrm{N}$ than secondary decomposers or predators, but the contribution to body tissue element concentration was low suggesting that they predominantly rely on other resources than litter from the previous year. Generally, soil mites incorporated more $\mathrm{C}$ and $\mathrm{N}$ from ash than from beech litter, but this was less pronounced after 10 as compared to after 5 months, presumably due to fast decomposition of ash litter. In contrast to our expectations the use of litter resources by soil mites was little affected by mycorrhiza. Overall, the results underline that, at least during the first year of litter decay, leaf litter resources are of minor importance for soil mite nutrition, and this is particularly true for litter rich in structural compounds such as beech.
\end{abstract}

Keywords: Litter decomposition; Litter quality; Mesostigmata; Oribatida; Soil food web; Stable isotope 


\section{Introduction}

Soil animal food webs are connected to the aboveground system via litter input and root-derived resources with the root pathway being of significant importance (Ruf et al. 2006; Pollierer et al. 2012). In forests and scrublands typically about $70-90 \%$ of the net primary production is channeled as detritus into the decomposer system (Cebrian 1999). Litter decomposition depends on various factors such as climatic conditions, litter quality and decomposer organisms (Swift et al. 1979; Couteaux et al. 1995).

Soil animals modify the decomposition of litter by translocation from the soil surface and mixing with mineral soil, fragmenting litter, and altering the activity and composition of microbial communities (Hanlon \& Anderson 1979; Hättenschwiler et al. 2005). Soil mites such as Oribatida and Mesostigmata are among the most widespread, abundant and species rich soil arthropods in forest soils (Schaefer 1990), and play important roles in nutrient cycling (Berg et al. 2001). The diversity of soil mites is reflected by their diversity of feeding habits including primary and secondary decomposers as well as predators (Brussaard et al. 1997). Mesostigmata are mainly predacious (Koehler 1999; Klarner et al. 2013), while Oribatida span over a wide range of trophic levels (Schneider et al. 2004).

Leaf litter is a challenging food source as nitrogen $(\mathrm{N})$ concentrations are low compared to $\mathrm{N}$ demand of animals. Most litter carbon (C) is bound in structural compounds such as cellulose, hemicellulose and lignin, which are not readily available for animals (Hättenschwiler \& Bretscher 2001). The great majority of such structural litter compounds are processed by saprotrophic fungi and bacteria (Pomeroy 1970; Petersen \& Luxton 1982). Therefore, litter $C$ and nutrients are likely to be channeled to higher trophic levels, such as detritivorous animals and predators, via fungal and bacterial energy channels (Moore \& Hunt 1988; Moore et al. 1988; Pollierer et al. 2012). In European beech (Fagus sylvatica) forests the fungal energy channel benefits from beech roots releasing acids thereby favoring fungi (Rousk et al. 2009; Langenbruch et al. 2012). In addition, litter of beech is rich in structural compounds such as lignin which are degraded predominantly by fungi (De Boer et al. 2005). The bacterial energy channel is assumed to be more important in leaf litter material of high quality which is decomposing quickly and in processing easily available substrates such as sugars and amino acids (Moore et al. 2004; Wardle et al. 2004).

Besides saprotrophic microorganisms, mycorrhiza are also present in soils and they affect decomposition processes (Gadgil \& Gadgil 1971; Hodge et al. 2001), but the mechanisms are poorly understood (Koide \& Wu 2003). Mycorrhiza may dilute the flux of litter C into soil invertebrates due to the channeling of root $\mathrm{C}$ into soil food webs.

We investigated effects of leaf litter species differing in structural compounds on the transfer of litter C and $\mathrm{N}$ into soil mites (Vesterdal et al. 2008; Cornwell et al. 2008). In contrast to previous 
studies investigating either leaf litter C or N (Caner et al. 2004; Pollierer et al. 2007, 2009), incorporation of both $\mathrm{C}$ and $\mathrm{N}$ into soil mite species was investigated. To investigate the importance of structural compounds for the nutrition of soil mites and the transfer of $\mathrm{C}$ and $\mathrm{N}$ into the soil animal food web, European ash (Fraxinus excelsior) and beech litter differing markedly in structural compounds, but with similar $\mathrm{N}$ concentrations, were used. The impact of mycorrhizal fungi on decomposition and soil mite nutrition was investigated by rotating mesocosms at regular intervals thereby interrupting ingrowth of mycorrhizal hyphae (Johnson et al. 2001; Leifheit et al. 2014).

The following hypotheses were investigated: (1) primary decomposers incorporate most litter C and $\mathrm{N}$ via directly feeding on litter; secondary decomposers incorporate intermediate amounts as they also feed on bacteria and fungi processing older litter from previous years, rather than litter from the last growth period, whereas predators incorporate least amounts as they feed on prey also relying on root-derived resources not labeled in this experiment; (2) soil mites incorporate more $\mathrm{C}$ and $\mathrm{N}$ from ash litter low in structural compounds and preferentially incorporate ash $\mathrm{C}$ and $\mathrm{N}$ in litter mixtures with beech; and (3) the presence of mycorrhiza dilutes litter $\mathrm{C}$ and $\mathrm{N}$ incorporation into soil microarthropods.

\section{Material and Methods}

\subsection{Study site}

The experiment was set up in a beech forest in the Hainich National Park near Mülverstedt $\left(51^{\circ} 06^{\prime} \mathrm{N}, 10^{\circ} 27^{\prime} \mathrm{E}\right)$ at $320 \mathrm{~m}$ asl. The Hainich National Park is located in Central Germany (Thuringia) and covers 16,000 ha. Mean annual temperature is $7.5^{\circ} \mathrm{C}$ and mean annual precipitation is $670 \mathrm{~mm}$ (Meteomedia, station Weberstedt/ Hainich, $51^{\circ} 10^{\prime} \mathrm{N}, 10^{\circ} 52^{\prime} \mathrm{E}$ ). The beech forest stocks on Luvisol developed on loess underlain by Triassic Limestone. The forest floor is classified as mull-like moder with a mean thickness of the litter layer of $2.8 \pm 0.1 \mathrm{~cm}$ (Jacob et al. 2010). The topsoil $(0-10 \mathrm{~cm}$ ) is rather acidic with a $\mathrm{pH}_{\mathrm{H} 2 \mathrm{O}}$ of $4.2-4.4$ (Guckland et al. 2009).

\subsection{Leaf litter}

For ${ }^{13} \mathrm{C}$ labeling young beech and ash trees were exposed to ${ }^{13} \mathrm{CO}_{2}$ enriched atmosphere $\left(\delta^{13} \mathrm{C} \approx\right.$ $300 \%$ ) in a greenhouse for 5 months; average temperature and humidity were $22.8^{\circ} \mathrm{C}$ and $72 \%$, respectively. For ${ }^{15} \mathrm{~N}$ labeling and to establish similar nutrient conditions tree saplings were irrigated daily with a Hoagland-based nutrient solution containing $0.1 \mathrm{mM}$ double labeled ammonium nitrate $\left({ }^{15} \mathrm{NO}_{3}{ }^{15} \mathrm{NH}_{4}\right.$, Euriso-top, Saint-Aubin, Essonne, France). Before experimental setup $\delta^{13} \mathrm{C}$ and $\delta^{15} \mathrm{~N}$ values and chemical composition of labeled and unlabeled leaf litter material were determined. Lignin content was determined by Langenbruch et al. (2014) using the acetyl bromide method after Brinkmann et al. (2002). Cellulose was extracted with methanol:chloroform:water solution (2:2:1; modified after Dickson, 1979). The water-methanol fraction were kept for $\alpha$-cellulose analysis 
according to Allen et al. (1974). $\delta^{13} \mathrm{C}$ and $\delta^{15} \mathrm{~N}$ values of beech were $118.1 \pm 1.7 \%$ ond $3143 \pm$ $229.2 \%$, respectively. $\delta^{13} \mathrm{C}$ and $\delta^{15} \mathrm{~N}$ values of ash were $155.0 \pm 5.2 \%$ and $26,924 \pm 1813 \%$, respectively. Labeled beech and ash litter had similar $N$ concentrations $(21.3 \pm 0.4$ and $19.9 \pm 0.9$ $\mathrm{mg} \mathrm{g}^{-1}$ litter dry weight, respectively) and C-to-N ratios (23.1 and 22.9), but differed in concentrations of cellulose (135.2 \pm 5.5 and $95.3 \pm 4.2 \mathrm{mg} \mathrm{g}^{-1}$ litter dry weight) and lignin (see Langenbruch et al. (2014) (241.0 \pm 4.1 and $178.1 \pm 2.1 \mathrm{mg} \mathrm{g}^{-1}$ litter dry weight).

\subsection{Experimental setup}

A total of 42 mesocosms were installed within a $50 \times 50$ m fenced area of the study site in December 2008. Undisturbed cores of the upper $5 \mathrm{~cm}$ of the mineral soil of a diameter of $24 \mathrm{~cm}$ were placed into plastic cylinders which were covered by $50 \mu \mathrm{m}$ mesh at the bottom and by $1 \mathrm{~mm}$ mesh at the top allowing water to pass and hyphae to grow in, but preventing colonization by animals and ingrowth of roots.

The litter layer was removed and replaced by $14.4 \mathrm{~g}$ of labeled litter in pure treatments and mixed litter treatments receiving $7.2 \mathrm{~g}$ of each beech and ash litter; the amount of litter added resembled the amount present in the litter layer at the study site. Mesocosms were placed at a distance of $1 \mathrm{~m}$ from each other and $2 \mathrm{~m}$ apart from tree stems into the soil to a depth that the soil and litter layer inside matched those outside the mesocosms. Four treatments differing in litter composition were established: (1) labeled beech litter only, (2) labeled ash litter only, (3) mixture of labeled beech and unlabeled ash litter, (4) mixture of labeled ash and unlabeled beech litter. One half of the mesocosms were rotated each 14 days to interrupt hyphal connections between the outside and inner soil layers, thereby establishing treatments without (M-) and with mycorrhiza $(\mathrm{M}+)$. To investigate natural variations in stable isotope ratios in soil animals and to allow calculations of shifts in stable isotope values due to the addition of labeled litter, three control treatments with unlabeled litter were established: (1) pure beech litter, (2) pure ash litter, and (3) mixture of beech and ash litter. Unlabeled beech and ash litter was sampled in the Hainich National Park; signatures of $\delta^{13} \mathrm{C}$ and $\delta^{15} \mathrm{~N}$ did not differ significantly and averaged $-28.8 \pm 0.5 \%$ and $-0.9 \pm$ $1.0 \%$, respectively (Langenbruch et al. 2014). Each treatment was replicated three times. Leaf litter-derived ${ }^{13} \mathrm{CO}_{2}$ production was measured during the experiment (Langenbruch et al. 2014) and reached maximum levels after 5 months, i.e. by the time of the first sampling.

\subsection{Stable isotope analyses of soil animals}

Five (May 2009) and 10 months (October 2009) after establishment, the experiment was destructively sampled. For sampling of soil animals, the litter layer was separated from the mineral soil and animals in both layers were extracted by heat using a high-gradient canister method (Kempson et al. 1963). Thereafter, soil animals were transferred into $70 \%$ ethanol and identified to species level. For stable isotope analyses, two soil mite species (Platynothrus peltifer, 
Steganacarus magnus) from the sampling after 5 months and six soil mite species (P. peltifer, $S$. magnus, Damaeus riparius, Nothrus silvestris, Uroseius cylindricus and Veigaia nemorensis) from the sampling after 10 months were transferred into tin capsules at weights corresponding to a minimum of $10 \mu \mathrm{g} \mathrm{N}$ per sample. For most mite species several individuals had to be pooled and therefore only abundant species could be used. Analyses of ${ }^{15} \mathrm{~N} /{ }^{14} \mathrm{~N}$ and ${ }^{13} \mathrm{C} /{ }^{12} \mathrm{C}$ ratios were carried out using a coupled system consisting of an elemental analyzer (NA 1500, Carlo Erba, Milan, Italy) and a mass spectrometer (MAT 251, Finnigan, Bremen, Germany) (Reineking et al. 1993; Langel \& Dyckmans 2014). Abundances of ${ }^{13} \mathrm{C}$ and ${ }^{15} \mathrm{~N}$ were expressed using the $\delta$ notation as

$$
\delta_{\text {sample }}[\% 0]=\frac{\mathrm{R}_{\text {sample }}-\mathrm{R}_{\text {standard }}}{\mathrm{R}_{\text {standard }}} \times 1000
$$

with $R_{\text {sample }}$ and $R_{\text {standard }}$ the ${ }^{13} \mathrm{C} /{ }^{12} \mathrm{C}$ and ${ }^{15} \mathrm{~N} /{ }^{14} \mathrm{~N}$ ratios of samples and standard, respectively. For ${ }^{13} \mathrm{C}$ PD Belemnite (PBD) and for ${ }^{15} \mathrm{~N}$ atmospheric $\mathrm{N}$ served as the primary standard. Acetanilide $\left(\mathrm{C}_{8} \mathrm{H}_{9} \mathrm{NO}\right.$, Merck, Darmstadt, Germany) was used for internal calibration.

Incorporation of litter $\mathrm{C}\left(\mathrm{C}_{\text {incorp }}\right)$ and $\mathrm{N}\left(\mathrm{N}_{\text {incorp }}\right)$ was calculated as enrichment in ${ }^{13} \mathrm{C}$ and ${ }^{15} \mathrm{~N}$ in animals $\left(\delta A^{*}-\delta A\right)$ relative to the enrichment in litter $\left(\delta L^{*}-\delta L\right)$ and given as percentages

$$
\mathrm{C}_{\text {incorp }} \text { or } \mathrm{N}_{\text {incorp }}[\%]=\frac{\left(\delta \mathrm{A}^{*}-\delta \mathrm{A}\right)}{\left(\delta \mathrm{L}^{*}-\delta \mathrm{L}\right)} \times 100
$$

with $\delta A^{*}$ - $\delta A$ representing the difference in delta values of $C$ or $N$ in soil animal tissue between treatments with labeled $\left(A^{*}\right)$ and control litter $(A)$; respectively, $\delta L^{*}-\delta L$ represents differences in delta values of $\mathrm{C}$ or $\mathrm{N}$ of labeled $\left(\mathrm{L}^{*}\right)$ and control litter ( $\mathrm{L}$ ). Incorporation of $\mathrm{C}$ and $\mathrm{N}$ into soil animal species was calculated for each of the four treatments with labeled litter (see above). For $\delta A$ mean stable isotope signatures of soil animal species in the three treatments with unlabeled litter were used (see above).

\subsection{Statistical analyses}

Statistical analyses were performed using the statistical software R v. 3.0.1 (R Development Core Team 2013) and the ' $n$ Ime' package (Pinheiro et al. 2013). Incorporation of litter $C$ and $N$ into soil mites after 10 months were analyzed separately using linear mixed effects models. Including a random effect of 'mesocosm ID' allowed inspecting the effect of animal species, beech and ash litter from single species treatments as compared to mixed litter treatments on litter $\mathrm{C}$ and $\mathrm{N}$ incorporation avoiding pseudo-replication of species within one mesocosm. Fixed factors were Labeled litter species (beech, ash), Mixture (single litter species, two litter species), Animal species (P. peltifer, S. magnus, D. riparius, N. silvestris, U. cylindricus and V. nemorensis) and Mycorrhiza (present, not present). Ratios of incorporated litter $\mathrm{C}$ and $\mathrm{N}$ into individual soil mite species were analyzed separately for sampling date ( 5 and 10 months after start of the experiment) using orial ANOVA; fixed factors were Labeled litter species (beech, ash), Mixture (single litter species, two litter species) and Mycorrhiza (present, not present). Prior to statistical analysis homogeneity of 
variances was inspected using Lévene test; ratio data were logit-transformed. Tukey post hoc tests (HSD) were performed to inspect differences between species. Data given in text and figures represent means and standard deviations.

\section{Results}

Natural abundance ${ }^{15} \mathrm{~N}$ signatures spanned $11 \delta$ units and ${ }^{13} \mathrm{C}$ signatures spanned $5.6 \delta$ units in the six analyzed soil mite species. For $\delta^{15} \mathrm{~N}$ they increased in the order P. peltifer $(-4.77 \pm 0.63 \%$ o $)<$ S. magnus $(-3.77 \pm 1.37 \%$ \% $)<D$. riparius $(-0.92 \pm 0.91 \%$ o $)<N$. silvestris $(2.08 \pm 1.59 \%$ o $)<V$. nemorensis $(5.23 \pm 1.05 \%)<U$. cylindricus $\left(6.41 \pm 1.77 \%\right.$ o). Respective values for $\delta^{13} \mathrm{C}$ were -25.55 $\pm 0.27,-19.95 \pm 0.75,-25.47 \pm 0.49,-24.32 \pm 0.49,-22.89 \pm 0.37$ and $-21.93 \pm 0.37 \%$.

Tab. 2.1: F- and P-values of three factorial ANOVA on the effect of tree species ("Tree": beech and ash), mixture ("Mix": pure and mixed) and mycorrhiza ("Myc": absent and present) on the incorporation of leaf litter carbon (C) and nitrogen (N) into soil mites after 5 months. A: Platynothrus peltifer and B: Steganacarus magnus.

A: Platynothrus peltifer

\begin{tabular}{lrrrr}
\hline Element & \multicolumn{4}{c}{$\mathbf{C} \mathbf{N}$} \\
\hline Fixed factor & F-value & $\mathrm{p}$-value & F-value & $\mathrm{p}$-value \\
\hline Tree & 56.12 & $<\mathbf{0 . 0 0 1}$ & 3.46 & 0.088 \\
Mix & 23.89 & $<\mathbf{0 . 0 0 1}$ & 6.18 & $\mathbf{0 . 0 2 9}$ \\
Myc & 5.63 & $\mathbf{0 . 0 3 5}$ & 0.05 & 0.835 \\
Tree $\times$ Mix & 14.74 & $\mathbf{0 . 0 0 2}$ & 1.07 & 0.320 \\
Tree $\times$ Myc & 4.35 & 0.059 & 0.60 & 0.452 \\
Mix $\times$ Myc & 3.86 & 0.073 & 0.07 & 0.797 \\
Tree $\times$ Mix $\times$ Myc & 6.58 & $\mathbf{0 . 0 2 5}$ & 1.37 & 0.265 \\
\hline
\end{tabular}

B: Steganacarus magnus

\begin{tabular}{|c|c|c|c|c|}
\hline Element & C & & $\mathbf{N}$ & \\
\hline Fixed factor & F-value & $p$-value & F-value & $p$-value \\
\hline Tree & 18.26 & 0.001 & 2.16 & 0.170 \\
\hline Mix & 3.20 & 0.101 & 1.53 & 0.243 \\
\hline Myc & 1.55 & 0.238 & 1.16 & 0.305 \\
\hline Tree $\times$ Mix & 3.93 & 0.073 & 2.22 & 0.164 \\
\hline Tree $\times$ Myc & 1.16 & 0.304 & 0.01 & 0.944 \\
\hline Mix $\times$ Myc & 3.97 & 0.072 & 2.77 & 0.125 \\
\hline Tree $\times$ Mix $\times$ Myc & 2.84 & 0.120 & 1.08 & 0.322 \\
\hline
\end{tabular}

After 5 months of the experiment, P. peltifer and S. magnus were significantly enriched in ${ }^{13} \mathrm{C}$ and ${ }^{15} \mathrm{~N}$ in treatments with labeled beech and ash litter by up to $29.2 \%$ and $4403 \%$ os compared to unlabeled treatments. This reflects the incorporation of similar amounts of litter-derived $\mathrm{C}$ and N, i.e. on average $6.07 \pm 4.91$ and $5.72 \pm 4.48 \%$, respectively. However, P. peltifer and S. magnus 
incorporated more $C$ from ash $(9.65 \pm 2.81 \%$ and $10.32 \pm 4.24 \%$, respectively) as compared to beech litter $(2.37 \pm 2.23 \%$ and $2.29 \pm 2.90 \%$, respectively; Tables $2.1 \mathrm{~A}, \mathrm{~B}$, Fig. 2.1). Further, P. peltifer incorporated more litter $\mathrm{C}$ in single litter treatments than in treatments with litter mixtures and this was more pronounced in labeled beech than labeled ash litter treatments (significant Labeled litter species $\times$ Mixture interaction; Table 2.1A). The effect of mycorrhiza on the incorporation of litter $\mathrm{C}$ into $P$. peltifer depended on Labeled litter species and Mixture. In presence of mycorrhiza the incorporation of litter $\mathrm{C}$ into $P$. peltifer was increased in ash litter only treatments and in mixed treatments with labeled beech litter, whereas it was reduced in treatments with beech litter only and in mixed treatments with labeled ash litter (significant Labeled litter species $x$ Mixture $\times$ Mycorrhiza interaction; Table 2.1A, Fig. 2.1).
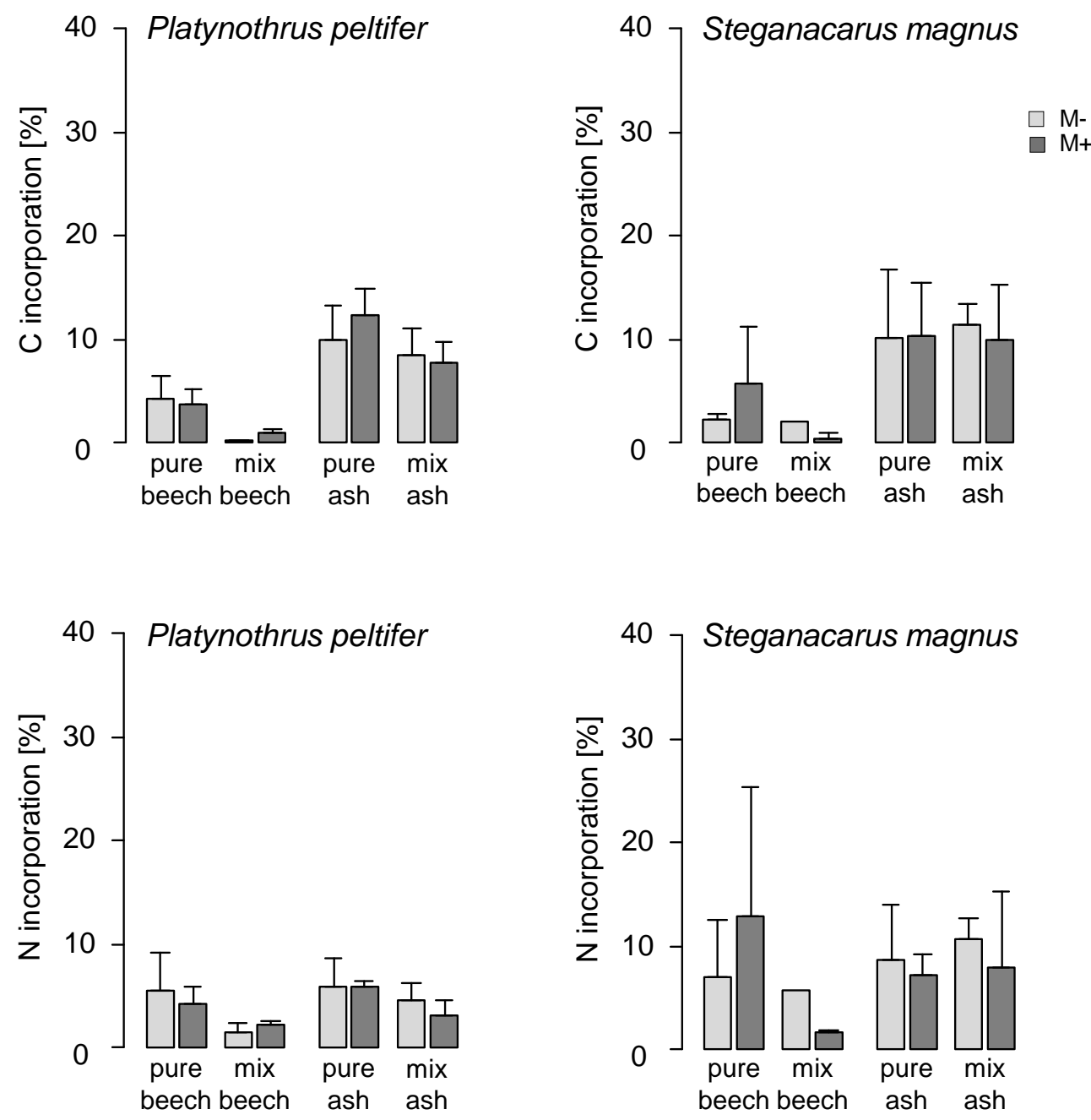

Fig. 2.1: Incorporation of carbon (C) and nitrogen (N) (means \pm standard deviation) from labeled beech litter in monoculture (pure beech) and mixture with unlabeled ash litter (mix beech), and from labeled ash litter in monoculture (pure ash) and mixture with unlabeled beech litter (mix ash) into primary decomposers in absence (M-) and presence of mycorrhiza $(\mathrm{M}+)$ after 5 months of incubation.

After 10 months, soil mites in treatments with labeled beech and ash litter were highly enriched in ${ }^{13} \mathrm{C}$ and ${ }^{15} \mathrm{~N}$ by up to 60.4 and $5582 \%$, respectively. On average, $6.69 \pm 6.18$ and $6.33 \pm 5.41 \%$ 
litter $\mathrm{C}$ and $\mathrm{N}$ were incorporated, respectively. However, soil mites differentially incorporated litter $C$ in labeled beech and ash litter treatments (significant Litter species $\times$ Animal species interaction; Table 2.2, Fig. 2.2). This was due to high incorporation of $C$ into $N$. silvestris, $V$. nemorensis and $U$. cylindricus in labeled ash litter treatments (Table 2.3). In contrast, D. riparius incorporated significantly more litter $C$ in treatments with labeled beech litter. Overall, presence of mycorrhiza reduced the incorporation of $\mathrm{C}$ into soil mites in labeled ash litter treatments, whereas in labeled beech litter treatments it was increased (significant Labeled litter species $\times$ Mycorrhiza interaction; Table 2.2), with the latter being mainly due to high $C$ incorporation in S. magnus and V. nemorensis (Fig. 2.2).

Tab. 2.2: F- and p-values of four factorial linear mixed effect model (LME) on the effect of animal species ("Species"), tree species ("Tree": beech and ash), litter mixture ("Mix": pure and mixed) and mycorrhiza ("Myc": absent and present) on the incorporation of carbon (C) and nitrogen (N) into soil animals. Fourfold interaction was removed from the models.

\begin{tabular}{lrrrr}
\hline & \multicolumn{4}{c}{$\mathbf{N}$} \\
\hline & F-value & p-value & F-value & p-value \\
\hline Species & 27.71 & $<\mathbf{0 . 0 0 1}$ & 32.11 & $<\mathbf{0 . 0 0 1}$ \\
Tree & 5.86 & $\mathbf{0 . 0 2 8}$ & 2.17 & 0.160 \\
Mix & 20.51 & $<\mathbf{0 . 0 0 1}$ & 12.33 & $\mathbf{0 . 0 0 3}$ \\
Myc & 6.39 & $\mathbf{0 . 0 2 2}$ & 1.24 & 0.283 \\
Species $\times$ Tree & 6.36 & $<\mathbf{0 . 0 0 1}$ & 3.34 & $\mathbf{0 . 0 1 0}$ \\
Species $\times$ Mix & 2.48 & $\mathbf{0 . 0 4 2}$ & 2.02 & 0.089 \\
Tree $\times$ Mix & 1.16 & 0.297 & 0.67 & 0.425 \\
Species $\times$ Myc & 0.66 & 0.654 & 2.17 & 0.070 \\
Tree $\times$ Myc & 5.47 & $\mathbf{0 . 0 3 3}$ & 7.49 & $\mathbf{0 . 0 1 5}$ \\
Mix $\times$ Myc & 0.15 & 0.701 & 0.28 & 0.607 \\
Species $\times$ Tree $\times$ Mix & 1.66 & 0.159 & 0.52 & 0.762 \\
Species $\times$ Tree $\times$ Myc & 1.65 & 0.162 & 3.05 & $\mathbf{0 . 0 1 6}$ \\
Species $\times$ Mix $\times$ Myc & 0.75 & 0.590 & 0.66 & 0.655 \\
Tree $\times$ Mix $\times$ Myc & 1.06 & 0.318 & 0.01 & 0.920 \\
\hline
\end{tabular}

On average, soil mites, in particular $N$. silvestris and $V$. nemorensis, incorporated more litter $\mathrm{N}$ in labeled ash litter treatments, but this was not true for $D$. riparius and P. peltifer (significant Labeled litter species $\times$ Animal species interaction; Tables 2.2, 2.3, Fig. 2.3). Similar to C, incorporation of litter $\mathrm{N}$ into soil mites varied with litter species and presence of mycorrhiza (significant Labeled litter species $\times$ Animal species $\times$ Mycorrhiza interaction; Table 2.2). In S. magnus presence of mycorrhiza significantly increased incorporation of litter $\mathrm{N}$ in labeled beech litter treatments, but reduced incorporation of litter $\mathrm{N}$ in labeled ash litter treatments (significant Litter species $\times$ Mycorrhiza interaction; Table 2.3, Fig. 2.3). In presence of mycorrhiza $P$. peltifer, $N$. silvestris, V. nemorensis and U. cylindricus incorporated less litter N (Table 2.3, Fig. 2.3). 

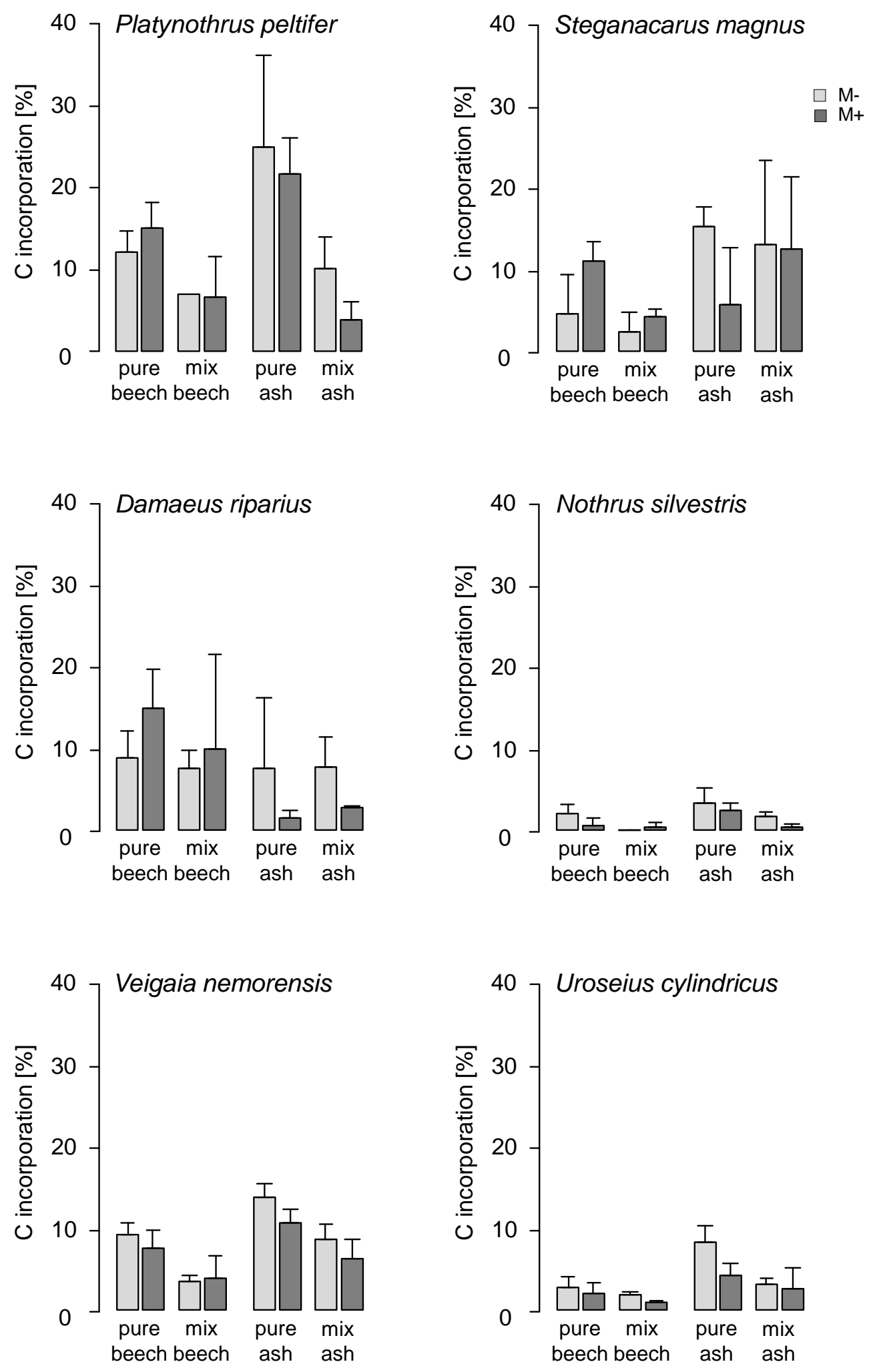

Fig. 2.2: Incorporation of carbon (C) (means \pm standard deviation) from labeled beech litter in monoculture (pure beech) and mixture with unlabeled ash litter (mix beech), and from labeled ash litter in monoculture (pure ash) and mixture with unlabeled beech litter (mix ash) into soil mite species from beech and ash litter in absence (M-) and presence of mycorrhiza ( $\mathrm{M}+$ ) after 10 months of incubation. As indicated by Tukey's HSD means increased in the order $N$. silvestris $<U$. cylindricus $=V$. nemorensis $=D$. riparius $=S$. magnus $=$ $P$. peltifer $(P<0.05)$. 

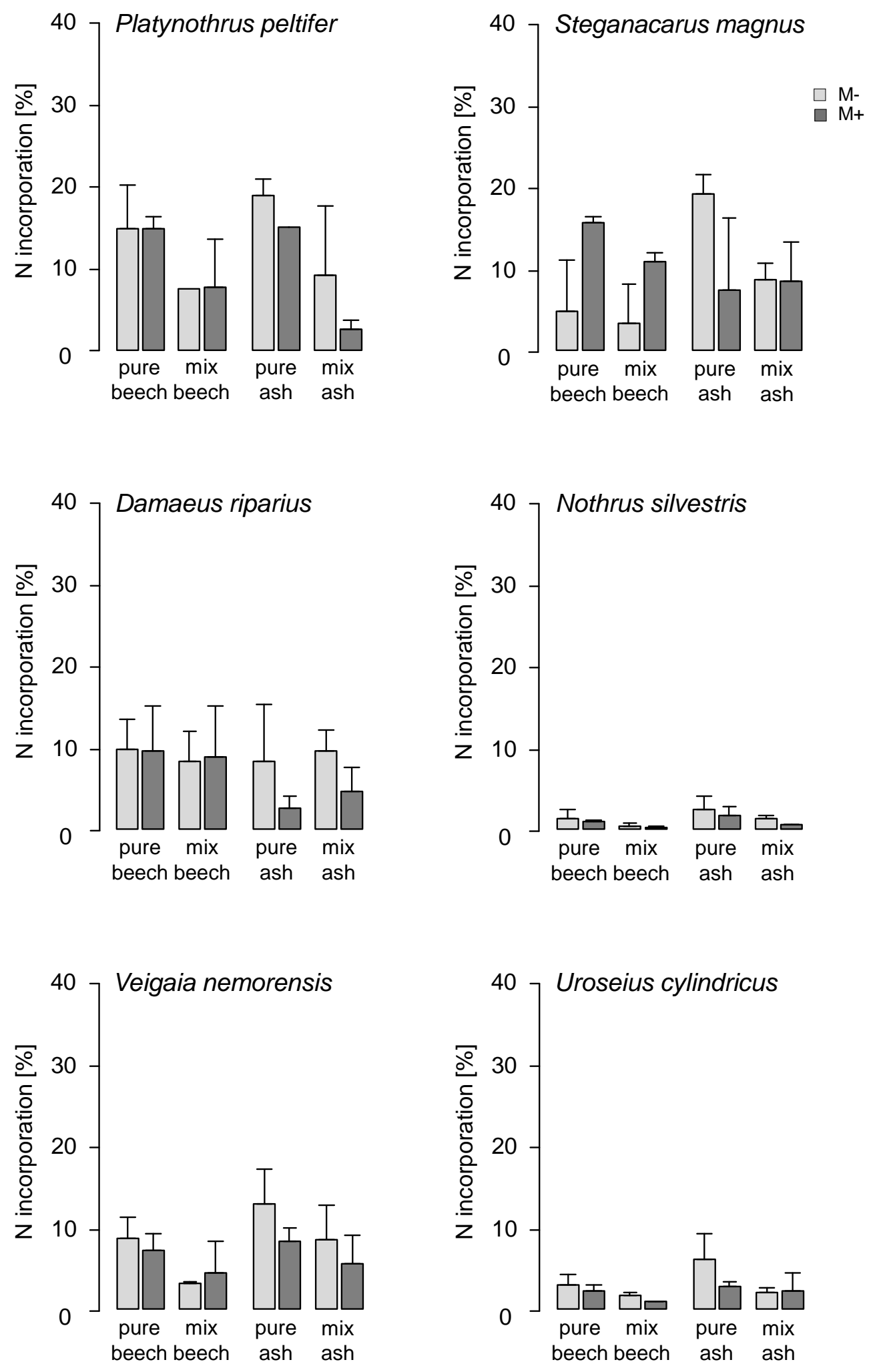

Fig. 2.3: Incorporation of nitrogen $(N)$ (means \pm standard deviation) from labeled beech litter in monoculture (pure beech) and mixture with unlabeled ash litter (mix beech), and from labeled ash litter in monoculture (pure ash) and mixture with unlabeled beech litter (mix ash) into soil mite species from beech and ash litter in absence (M-) and presence of mycorrhiza (M+) after 10 months of incubation. As indicated by Tukey's HSD means increased in the order $N$. silvestris $<U$. cylindricus $=V$. nemorensis $=D$. riparius $=S$. magnus $=$ $P$. peltifer $(\mathrm{P}<0.05)$. 
Tab. 2.3: Means in \%, SD (standard deviation) and F-values of three factorial ANOVA on the effect of tree species ("Tree": beech and ash) and mixture ("Mix": pure and mixed) and mycorrhiza ("Myc": absent and present) on the incorporation of leaf litter carbon (C) and nitrogen (N) into soil mite species. *

\section{Carbon incorporation}

\begin{tabular}{|c|c|c|c|c|c|c|c|c|c|c|}
\hline Species & $\mathrm{N}$ & Mean & SD & Tree & Mix & Myс & Tree $\times$ Mix & Tree $\times$ Myc & Mix $\times$ Myc & Tree $\times$ Mix $\times$ Myc \\
\hline Platynothrus peltifer & 16 & 12.65 & 58.28 & 31.05 & $15.72 * *$ & 1.08 & 1.28 & 0.96 & 1.50 & 0.09 \\
\hline Steganacarus magnus & 17 & 8.82 & 26.75 & 2.20 & 0.06 & 0.02 & 1.93 & 3.88 & 0.60 & 1.10 \\
\hline Damaeus riparius & 21 & 7.76 & 66.22 & $8.57^{*}$ & 0.04 & 1.67 & 2.81 & 4.05 & 0.11 & 0.48 \\
\hline Nothrus silvestris & 19 & 1.32 & 21.31 & $8.25^{*}$ & $10.87 * *$ & 1.97 & 0.13 & 0.73 & 0.52 & 6.45 \\
\hline Veigaia nemorensis & 22 & 7.63 & 33.55 & $16.13 * *$ & $23.90 * * *$ & 2.59 & 1.34 & 0.39 & 0.04 & 0.19 \\
\hline Uroseius cylindricus & 22 & 3.38 & 82.46 & $12.32 * *$ & $9.86 * *$ & $6.32 *$ & 0.54 & 0.05 & 0.02 & 0.55 \\
\hline
\end{tabular}

\section{Nitrogen incorporation}

\begin{tabular}{|c|c|c|c|c|c|c|c|c|c|}
\hline Species & $\mathrm{N}$ & Mean SD & Tree & Mix & Myс & Tree $\times$ Mix & Tree $\times$ Myc & Mix $\times$ Myc & Tree $\times$ Mix $\times$ Myc \\
\hline Platynothrus peltifer & 16 & 611.356 .29 & 7 0.25 & $11.53 * *$ & 1.32 & 1.00 & 0.81 & 0.64 & 0.23 \\
\hline Steganacarus magnus & 17 & 9.685 .98 & 1.28 & 0.39 & 1.33 & 0.22 & $5.23 *$ & 0.64 & 0.06 \\
\hline Damaeus riparius & 21 & 7.654 .47 & 3.77 & 0.30 & 3.56 & 1.32 & 2.98 & 0.06 & 0.03 \\
\hline Nothrus silvestris & 19 & 1.070 .89 & $11.09 * *$ & $15.01 * *$ & 3.06 & 0.80 & 0.53 & 0.16 & 0.16 \\
\hline Veigaia nemorensis & 22 & 7.043 .57 & $5.54 *$ & $11.04 * *$ & 1.54 & 0.70 & 1.28 & 0.12 & 0.20 \\
\hline Uroseius cylindricus & 22 & 2.641 .98 & 3.01 & $11.46 * *$ & 3.38 & 0.03 & 0.04 & 0.06 & 0.69 \\
\hline
\end{tabular}




\section{Discussion}

\subsection{Trophic structure}

Natural variations in ${ }^{15} \mathrm{~N} /{ }^{14} \mathrm{~N}$ ratios allow ascribing species to trophic levels as ${ }^{15} \mathrm{~N}$ is enriched at higher trophic levels (Minagawa \& Wada 1984; Post 2002). Based on their $\delta^{15} \mathrm{~N}$ signatures the six analyzed soil mite species have been classified as primary decomposers (S. magnus, P. peltifer), secondary decomposers (D. riparius, N. silvestris) (Schneider et al. 2004) and first order predators (V. nemorensis, U. cylindricus) (Klarner et al. 2013). Primary decomposers mainly consume litter, while secondary decomposers are assumed to predominantly feed on microbes and their residues (Luxton 1972; Scheu \& Falca 2000). Predators have been assumed to predominantly feed on secondary decomposers in addition to intraguild predation (Scheu \& Setälä 2002; Pollierer et al. 2009). Primary decomposers presumably are of little importance as prey since they often are strongly sclerotized and large thereby living in enemy free space (Scheu \& Setälä 2002; Pollierer et al. 2009). The food spectrum of soil animals comprises resources from different trophic levels, such as detritus, microorganisms and invertebrates, with the fraction soil animals incorporate from these resources varying between species since stable isotope signatures form a continuum rather than fall into discrete levels (Scheu \& Falca 2000; Schneider et al. 2004).

\subsection{Incorporation of litter resources}

Each of the studied mite species incorporated litter-derived $\mathrm{C}$ and $\mathrm{N}$ suggesting that virtually all soil animal species at least to some extent rely on litter-derived resources. However, although each of the species studied incorporated litter resources, the contribution of these resources to animal nutrition was low accounting for only $1.32 \pm 1.31$ to $12.65 \pm 8.28 \%$ and $1.07 \pm 0.89$ to $11.35 \pm 6.29 \%$ of animal tissue $\mathrm{C}$ and $\mathrm{N}$ after 10 months, respectively. This reinforces the view that the importance of litter-derived resources in soil animal food webs is low and other resources, such as older litter from previous years or those derived from roots, are more important (Ruf et al. 2006; Pollierer et al. 2007). As under natural conditions, ash litter was almost entirely decomposed after 10 months (Jacob et al. 2010) and was no longer available for soil mite nutrition. Notably, incorporation of litter $\mathrm{C}$ and $\mathrm{N}$ into soil mites did not differ significantly, indicating that leaf litter $\mathrm{C}$ and $\mathrm{N}$ is incorporated simultaneously into soil animals.

Supporting our first hypothesis, incorporation of litter $\mathrm{C}$ and $\mathrm{N}$ was highest in primary decomposers (9.7 and $11.4 \%$ litter N in S. magnus and P. peltifer, respectively). This is in line with findings by Caner et al. (2004) who estimated the fraction of litter-derived $\mathrm{N}$ of total animal $\mathrm{N}$ to be 2-16\%. Considering that primary decomposers are feeding on litter, the observed incorporation of litter $\mathrm{C}$ and $\mathrm{N}$ is low. Therefore, the results suggest that even species occupying basal positions in the food web rely on older litter $\mathrm{C}$ and $\mathrm{N}$ resources, e.g. from older leaf litter forming part of soil 
organic matter (Albers et al. 2006). Indeed, it has been shown that oribatid mites preferentially feed on litter heavily attacked by fungi (Rihani et al. 1995). This confirms results of earlier studies suggesting that freshly fallen leaves are of poor nutritional value for soil detritivores and first need to be attacked by microorganisms releasing exo-enzymes thereby breaking down toxic compounds and softening leaf tissue before the leaves are accepted as food (Soma \& Saitô 1983; Hassall et al. 1987).

Similar to primary decomposers, $\mathrm{C}$ and $\mathrm{N}$ of secondary decomposers in large originated from other resources than the leaf litter added, presumably old organic matter, but also root-derived resources contributed to the nutrition of secondary decomposers (Pollierer et al. 2007, 2012). Since roots were cut when excavating the soil cores for the experiment, a flush of dead organic matter from roots likely entered the decomposer system. Feeding on microorganisms colonizing these resources presumably diluted the incorporation of $\mathrm{C}$ and $\mathrm{N}$ from litter into oribatid mites. As in secondary decomposers, predatory mites incorporated litter $\mathrm{C}$ and $\mathrm{N}$ documenting that leaf litter $\mathrm{C}$ and $\mathrm{N}$ is channeled to higher trophic levels, but litter $\mathrm{C}$ and $\mathrm{N}$ contributed less to their nutrition as compared to primary decomposers presumably due to the dilution of tracer $\mathrm{C}$ and $\mathrm{N}$ via feeding on prey relying on other resources than leaf litter, e.g. nematodes incorporating root-derived resources.

Compared to primary decomposers, variations in the incorporation of litter resources into the two studied secondary decomposers was more pronounced. Secondary decomposers are known to feed on a wide spectrum of fungal species (Ponge 2000; Schneider \& Maraun 2005), thereby improving their nutrition via mixed diets (Raubenheimer \& Simpson 1997). Feeding on fungal species varying in palatability and nutrient concentrations likely contributed to the differential incorporation of litter $\mathrm{C}$ and $\mathrm{N}$ in the two secondary decomposer oribatid mite species studied. $\mathrm{N}$. silvestris incorporated least litter $\mathrm{C}$ and $\mathrm{N}$ indicating that this species relies little on litter resources. As $N$. silvestris also incorporates little root C (S. Zieger, unpubl. data) it likely predominantly feeds on fungi relying on old organic matter resources. The predatory mite $U$. cylindricus incorporated less litter $\mathrm{C}$ and $\mathrm{N}$ compared to $\mathrm{V}$. nemorensis suggesting that in this species the litter pathway is of minor importance. It has been suggested that mesostigmatid mites predominantly feed on secondary decomposers such as nematodes and collembolans (Klarner et al. 2013). U. cylindricus is a slow moving mite, presumably feeding predominantly on slow moving prey such as nematodes. In contrast, $V$. nemorensis is actively hunting prey thereby catching mobile prey such as collembolans (Koehler 1999). Primary feeding on litter fungi in collembolans and close association of nematodes to root-derived resources may explain the differences in the incorporation of litterderived resources into $U$. cylindricus and $V$. nemorensis. 


\subsection{Leaf litter}

Three of the six analyzed soil mite species incorporated more ash than beech litter $\mathrm{C}$ and $\mathrm{N}$ after 10 months, supporting our hypothesis that ash litter $\mathrm{C}$ and $\mathrm{N}$ is more readily available for decomposer animals than beech litter $\mathrm{C}$ and $\mathrm{N}$. Food quality of litter materials for detritivorous animals is assumed to vary with litter $\mathrm{N}$ concentrations and ash litter is richer in nutrients than beech litter (Vesterdal et al. 2008; Jacob et al. 2009). However, due to fertilizer addition to trees during labeling, $\mathrm{N}$ concentrations and $\mathrm{C}$-to- $\mathrm{N}$ ratios of labeled beech and ash litter in our experiment differed little (Langenbruch et al. 2014). Therefore, differences in the incorporation of C and $N$ from beech and ash litter unlikely were due to differences in $\mathrm{N}$ concentrations. Rather, it was likely due to differences in structural litter compounds (Langenbruch et al. 2014).

Supporting our second hypothesis, after 5 months of the experiment both primary decomposers, S. magnus and P. peltifer, incorporated significantly more ash than beech leaf litter $C$, and $P$. peltifer switched to a more ash based diet in litter mixtures indicating preference for ash over beech litter. It has been shown earlier that beech litter is hard to digest for soil animals (Anderson 1973). Tensile strength and lignin concentration are possible drivers for the preference of decomposer animals for litter low in structural compounds (Perez-Harguindeguy et al. 2000). However, other litter properties such as lignin and $\mathrm{N}$ concentrations, which differed between labeled and unlabeled litter (Langenbruch et al. 2014), might have influenced the observed preference for ash litter in mixed treatments. Low incorporation of ash litter $\mathrm{C}$ and $\mathrm{N}$ after 10 months into primary decomposers presumably was due to the fact that ash litter had disappeared almost entirely at the end of the experiment (Langenbruch et al. 2014), documenting that despite similarities in $\mathrm{N}$ concentrations ash litter decomposed faster than beech litter. Deprivation of ash litter in the mixed litter treatment presumably also was responsible for the shift in $\mathrm{C}$ and $\mathrm{N}$ incorporation towards beech litter at the end of the experiment. However, this was not the case for secondary decomposers and predators as after 10 months they incorporated more $\mathrm{C}$ and $\mathrm{N}$ from ash than from beech litter, likely by feeding on secondary decomposers such as nematodes and collembolans.

\subsection{Mycorrhiza}

Accessibility of the mesocosms by mycorrhiza differentially affected litter $\mathrm{C}$ incorporation into soil mites; after 5 months $P$. peltifer incorporated more litter $C$ in presence of mycorrhiza while after 10 months presence of mycorrhiza reduced the incorporation of $C$ from labeled ash litter, whereas in treatments with labeled beech litter it was increased. Rotating the mesocosms not only may have reduced mycorrhizal but also those of other fungi (Leifheit et al. 2014). Notably, the mycorrhiza-mediated changes in litter $\mathrm{C}$ and $\mathrm{N}$ incorporation into soil mites resulted in an overall lower incorporation of ash as compared to beech leaf litter $\mathrm{C}$ and $\mathrm{N}$. In beech litter the reduction in 
fungal hyphae in rotated mesocosms might have decreased enzyme activity and thereby the availability of $\mathrm{C}$ and $\mathrm{N}$ for soil mites. In non-rotated ash litter mesocosms ingrowth of hyphae may have accelerated ash litter decomposition thereby contributing to low availability of ash litter $\mathrm{C}$ and $\mathrm{N}$ at the end of the experiment when ash litter was almost entirely decomposed. The primary decomposer $S$. magnus was the only species which incorporated more litter $\mathrm{N}$ than litter $\mathrm{C}$ in presence of mycorrhiza but only in beech treatments after 10 months. Potentially, S. magnus fed on mycorrhiza thereby accessing litter N but no litter C (Burke et al. 2014). Reduced incorporation of leaf litter $\mathrm{C}$ into the predatory mite $U$. cylindricus, in presence of mycorrhiza suggests that the negative effect of mycorrhiza on the incorporation of litter $\mathrm{C}$ and $\mathrm{N}$ into the soil animal food web also applies to predators documenting that changes in resource use by detritivores propagate to higher trophic levels.

\subsection{Conclusions}

Overall, the results suggest that the incorporation of leaf litter $\mathrm{C}$ and $\mathrm{N}$ into soil mites including primary decomposers is generally low. However, among trophic groups of soil mites incorporation was highest in primary decomposers, but the generally low incorporation of leaf litter resources suggests that even primary decomposers predominantly feed on other food resources than leaf litter, at least during the first year of decomposition. Notably, incorporation of litter-derived resources varied between soil mite species occupying the same trophic level in each of the three trophic levels studied, suggesting that litter $\mathrm{C}$ and $\mathrm{N}$ is channeled to higher tropic levels via distinct species specific pathways. Despite similar $\mathrm{N}$ concentrations, incorporation of $\mathrm{C}$ and $\mathrm{N}$ from ash litter exceeded that from beech litter, suggesting that incorporation of leaf litter resources into the soil animal food web varies with structural litter characteristics. After 10, but not after 5 months, presence of mycorrhiza reduced the incorporation of litter $\mathrm{C}$ and $\mathrm{N}$ into soil mites, presumably due to adding root-derived resources to the diet of decomposer microarthropods. 


\section{Acknowledgements}

This project was funded by the German Research Foundation (DFG). We are grateful to the administration of Hainich National Park for permission to conduct the study in the Hainich National Park. We thank Dieter Nünchert, Dr. Bernhard Klarner and Dr. Dominik Seidel for help in establishing the mesocosms. Jasmin Seven and Andrea Scheibe for help in the destructive sampling of the experiment. Further, we thank Prof. Dr. Andrea Polle for providing greenhouse space, Kerttu Valtanen for help in labeling tree seedlings, Christina Langenbruch for providing data on litter material, Ina Hoeft and Henning Mehrgott for assisting in sorting of animals, and the Kompetenzzentrum Stabile Isotope (KOSI, University of Göttingen) for measuring stable isotopes.

\section{References}

Albers, D., Schaefer, M. \& Scheu, S. (2006) Incorporation of plant carbon into the soil animal food web of an arable system. Ecology, 87, 235-245.

Allen, S.E., Grimshaw, H.M., Parkinson, J.A. \& Quarmby, C. (1974) Chemical Analysis of Ecological Materials. Blackwell Scientific Publications.

Anderson, J.M. (1973) The breakdown and decomposition of sweet chestnut (Castanea sativa Mill.) and beech (Fagus sylvatica L.) leaf litter in two deciduous woodland soils. Oecologia, 12, 251274.

Berg, M.P., de Ruiter, P.C., Didden, W., Janssen, M., Schouten, T. \& Verhoef, H. (2001) Community food web, decomposition and nitrogen mineralisation in a stratified Scots pine forest soil. Oikos, 94, 130-142.

De Boer, W., Folman, L.B., Summerbell, R.C. \& Boddy, L. (2005) Living in a fungal world: Impact of fungi on soil bacterial niche development. FEMS Microbiology Reviews, 29, 795-811.

Brinkmann, K., Blaschke, L. \& Polle, A. (2002) Comparison of Different Methods for Lignin Determination as a Basis for Calibration of Near-Infrared Reflectance Spectroscopy and Implications of Lignoproteins. Journal of Chemical Ecology, 28, 2483-2501.

Brussaard, L., Behan-Pelletier, V.M., Bignell, D.E., Brown, V.K., Didden, W., Folgarait, P., Fragoso, C., Freckman, D.W., Gupta, V., Hattori, T., Hawksworth, D.L., Klopatek, C., Lavelle, P., Malloch, D.W., Rusek, J., Soderstrom, B., Tiedje, J.M. \& Virginia, R.A. (1997) Biodiversity and ecosystem functioning in soil. Ambio, 26, 563-570.

Burke, D.J., Smemo, K.A. \& Hewins, C.R. (2014) Ectomycorrhizal fungi isolated from old-growth northern hardwood forest display variability in extracellular enzyme activity in the presence of plant litter. Soil Biology \& Biochemistry, 68, 219-222.

Caner, L., Zeller, B., Dambrine, E., Ponge, J.-F., Chauvat, M. \& Llanque, C. (2004) Origin of the nitrogen assimilated by soil fauna living in decomposing beech litter. Soil Biology \& Biochemistry, 36, 1861-1872.

Cebrian, J. (1999) Patterns in the fate of production in plant communities. The American Naturalist, 154, 449-468. 
Cornwell, W.K., Cornelissen, J.H.C., Amatangelo, K., Dorrepaal, E., Eviner, V.T., Godoy, O., Hobbie, S.E., Hoorens, B., Kurokawa, H., Pérez-Harguindeguy, N., Quested, H.M., Santiago, L.S., Wardle, D.A., Wright, I.J., Aerts, R., Allison, S.D., van Bodegom, P., Brovkin, V., Chatain, A., Callaghan, T. V., Díaz, S., Garnier, E., Gurvich, D.E., Kazakou, E., Klein, J.A., Read, J., Reich, P.B., Soudzilovskaia, N.A., Vaieretti, M.V. \& Westoby, M. (2008) Plant species traits are the predominant control on litter decomposition rates within biomes worldwide. Ecology Letters, 11, 1065-1071.

Couteaux, M.M., Bottner, P. \& Berg, B. (1995) Litter decomposition, climate and litter quality. Trends in Ecology and Evolution, 10, 63-66.

Dickson, R.E. (1979) Analytical Procedures for the Sequential Extraction of 14C-Labeled Constituents from Leaves, Bark and Wood of Cottonwood Plants. Physiologia Plantarum, 45, 480-488.

Gadgil, R.L. \& Gadgil, P.D. (1971) Mycorrhiza and litter decomposition. Nature, 233, 133-133.

Guckland, A., Jacob, M., Flessa, H., Thomas, F.M. \& Leuschner, C. (2009) Acidity, nutrient stocks, and organic-matter content in soils of a temperate deciduous forest with different abundance of European beech (Fagus sylvatica L.). Journal of Plant Nutrition and Soil Science, 172, 500 511.

Hanlon, R.D.G. \& Anderson, J.M. (1979) The effects of collembola grazing on microbial activity in decomposing leaf litter. Oecologia, 38, 93-99.

Hassall, M., Turner, J.G. \& Rands, M.R.W. (1987) Effects of terrestrial isopods on the decomposition of woodland leaf litter. Oecologia, 72, 597-604.

Hättenschwiler, S. \& Bretscher, D. (2001) Isopod effects on decomposition of litter produced under elevated $\mathrm{CO} 2, \mathrm{~N}$ deposition and different soil types. Global Change Biology, 7, 565-579.

Hättenschwiler, S., Tiunov, A. V. \& Scheu, S. (2005) Biodiversity and litter decomposition in terrestrial ecosystems. Annual Review of Ecology, Evolution, and Systematics, 36, 191-218.

Hodge, A., Campbell, C.D. \& Fitter, A.H. (2001) An arbuscular mycorrhizal fungus accelerates decomposition and acquires nitrogen directly from organic material. Nature, 413, 297-299.

Jacob, M., Viedenz, K., Polle, A. \& Thomas, F.M. (2010) Leaf litter decomposition in temperate deciduous forest stands with a decreasing fraction of beech (Fagus sy/vatica). Oecologia, 164, 1083-1094.

Jacob, M., Weland, N., Platner, C., Schaefer, M., Leuschner, C. \& Thomas, F.M. (2009) Nutrient release from decomposing leaf litter of temperate deciduous forest trees along a gradient of increasing tree species diversity. Soil Biology \& Biochemistry, 41, 2122-2130.

Johnson, D., Leake, J.R. \& Read, D.J. (2001) Novel in-growth core system enables functional studies of grassland mycorrhizal mycelial networks. New Phytologist, 152, 555-562.

Kempson, D., Lloyd, M. \& Ghelardi, R. (1963) A new extractor for woodland litter. Pedobiologia, 3, $1-21$.

Klarner, B., Maraun, M. \& Scheu, S. (2013) Trophic diversity and niche partitioning in a species rich predator guild - Natural variations in stable isotope ratios $(13 \mathrm{C} / 12 \mathrm{C}, 15 \mathrm{~N} / 14 \mathrm{~N})$ of mesostigmatid mites (Acari, Mesostigmata) from Central European beech forests. Soil Biology \& Biochemistry, 57, 327-333.

Koehler, H.H. (1999) Predatory mites (Gamasina, Mesostigmata). Agriculture, Ecosystems \& Environment, 74, 395-410. 
Koide, R.T. \& Wu, T. (2003) Ectomycorrhizas and retarded decomposition in a Pinus resinosa plantation. New Phytologist, 158, 401-407.

Langel, R. \& Dyckmans, J. (2014) Combined (13) C and (15) N isotope analysis on small samples using a near-conventional elemental analyzer/isotope ratio mass spectrometer setup. Rapid Communications in Mass Spectrometry, 28, 1019-1022.

Langenbruch, C., Helfrich, M. \& Flessa, H. (2012) Effects of beech (Fagus sylvatica), ash (Fraxinus excelsior) and lime (Tilia spec.) on soil chemical properties in a mixed deciduous forest. Plant and Soil, 352, 389-403.

Langenbruch, C., Helfrich, M., Joergensen, R.G., Gordon, J. \& Flessa, H. (2014) Partitioning of carbon and nitrogen during decomposition of $13 \mathrm{C} 15 \mathrm{~N}$-labeled beech and ash leaf litter. Journal of Plant Nutrition and Soil Science, 177, 178-188.

Leifheit, E.F., Verbruggen, E. \& Rillig, M.C. (2014) Rotation of hyphal in-growth cores has no confounding effects on soil abiotic properties. Soil Biology \& Biochemistry, 79, 78-80.

Luxton, M. (1972) Studies on the oribatid mites of a Danish beech wood soil. I. Nutritional biology. Pedobiologia, 12, 434-463.

Minagawa, M. \& Wada, E. (1984) Stepwise enrichment of $15 \mathrm{~N}$ along food chains: Further evidence and the relation between $\delta 15 \mathrm{~N}$ and animal age. Geochimica et Cosmochimica Acta, 48, 11351140.

Moore, J.C., Berlow, E.L., Coleman, D.C., Ruiter, P.C., Dong, Q., Hastings, A., Johnson, N.C., McCann, K.S., Melville, K., Morin, P.J., Nadelhoffer, K.J., Rosemond, A.D., Post, D.M., Sabo, J.L., Scow, K.M., Vanni, M.J. \& Wall, D.H. (2004) Detritus, trophic dynamics and biodiversity. Ecology Letters, 7, 584-600.

Moore, J.C. \& Hunt, H.W. (1988) Resource compartmentation and the stability of real ecosystems. Nature, 333, 261-263.

Moore, J.C., Walter, D.E. \& Hunt, H.W. (1988) Arthropod Regulation of Micro- and Mesobiota in Below-Ground Detrital Food Webs. Annual Review of Entomology, 33, 419-439.

Perez-Harguindeguy, N., Diaz, S., Cornelissen, J.H.C., Vendramini, F., Cabido, M. \& Castellanos, A. (2000) Chemistry and toughness predict leaf litter decomposition rates over a wide spectrum of functional types and taxa in central Argentina. Plant and Soil, 218, 21-30.

Petersen, H. \& Luxton, M. (1982) A comparative analysis of soil fauna populations and their role in decomposition processes. Oikos, 39, 288-388.

Pinheiro, J., Bates, D., DebRoy, S. \& Sarkar, D. (2013) nlme: Linear and Nonlinear Mixed Effects Models. R package ver. 3.1-120, R package.

Pollierer, M.M., Dyckmans, J., Scheu, S. \& Haubert, D. (2012) Carbon flux through fungi and bacteria into the forest soil animal food web as indicated by compound-specific $13 \mathrm{C}$ fatty acid analysis. Functional Ecology, 26, 978-990.

Pollierer, M.M., Langel, R., Körner, C., Maraun, M. \& Scheu, S. (2007) The underestimated importance of belowground carbon input for forest soil animal food webs. Ecology Letters, 10, 729-736.

Pollierer, M.M., Langel, R., Scheu, S. \& Maraun, M. (2009) Compartmentalization of the soil animal food web as indicated by dual analysis of stable isotope ratios (15N/14N and $13 \mathrm{C} / 12 \mathrm{C})$. Soil Biology \& Biochemistry, 41, 1221-1226.

Pomeroy, L.R. (1970) The strategy of mineral cycling. Annual Review of Ecology and Systematics, 1, 171-190. 
Ponge, J.-F. (2000) Vertical distribution of collembola (Hexapoda) and their food resources in organic horizons of beech forests. Biology and Fertility of Soils, 32, 508-522.

Post, D.M. (2002) Using stable isotopes to estimate trophic position: models, methods, and assumptions. Ecology, 83, 703-718.

Raubenheimer, D. \& Simpson, S.J. (1997) Integrative models of nutrient balancing: application to insects and vertebrates. Nutrition research reviews, 10, 151-179.

Reineking, A., Langel, R. \& Schikowski, J. (1993) C-On-line Measurements with an Elemental Analyser (Carlo Erba, NA 1500), a Modified Trapping Box and a Gas Isotope Mass Spectrometer (Finnigan, MAT 251). Isotopenpraxis Isotopes in Environmental and Health Studies, 29, 169174.

Rihani, M., Cancela da Fonseca, J.P. \& Kiffer, E. (1995) Decomposition of beech leaf litter by microflora and mesofauna. II. Food preferences and action of oribatid mites on different substrates. European Journal of Soil Biology, 31, 67-79.

Rousk, J., Brookes, P.C. \& Bååth, E. (2009) Contrasting soil pH effects on fungal and bacterial growth suggest functional redundancy in carbon mineralization. Applied and Environmental Microbiology, 75, 1589-1596.

Ruf, A., Kuzyakov, Y. \& Lopatovskaya, O. (2006) Carbon fluxes in soil food webs of increasing complexity revealed by $14 \mathrm{C}$ labelling and $13 \mathrm{C}$ natural abundance. Soil Biology \& Biochemistry, 38, 2390-2400.

Schaefer, M. (1990) The soil fauna of a beech forest on limestone: trophic structure and energy budget. Oecologia, 82, 128-136.

Scheu, S. \& Falca, M. (2000) The soil food web of two beech forests (Fagus sylvatica) of contrasting humus type: stable isotope analysis of a macro- and a mesofauna-dominated community. Oecologia, 123, 285-296.

Scheu, S. \& Setälä, H. (2002) Multitrophic interactions in decomposer food-webs. Multitrophic Level Interactions (eds T. Tscharntke), \& B.A. Hawkins), pp. 223-264. Cambridge University Press, Cambridge.

Schneider, K. \& Maraun, M. (2005) Feeding preferences among dark pigmented fungal taxa ("Dematiacea") indicate limited trophic niche differentiation of oribatid mites (Oribatida, Acari). Pedobiologia, 49, 61-67.

Schneider, K., Migge, S., Norton, R.A., Scheu, S., Langel, R., Reineking, A. \& Maraun, M. (2004) Trophic niche differentiation in soil microarthropods (Oribatida, Acari): evidence from stable isotope ratios (15N/14N). Soil Biology \& Biochemistry, 36, 1769-1774.

Soma, K. \& Saitô, T. (1983) Ecological studies of soil organisms with references to the decomposition of pine needles - II. Litter feeding and breakdown by the woodlouse, Porcellio scaber. Plant and Soil, 75, 139-151.

Swift, M.J., Heal, O.W. \& Anderson, J.M. (1979) Decomposition in Terrestrial Ecosystems. Blackwell Science, Oxford.

Vesterdal, L., Schmidt, I.K., Callesen, I., Nilsson, L.O. \& Gundersen, P. (2008) Carbon and nitrogen in forest floor and mineral soil under six common European tree species. Forest Ecology and Management, 255, 35-48.

Wardle, D.A., Bardgett, R.D., Klironomos, J.N., Setälä, H., van der Putten, W.H. \& Wall, D.H. (2004) Ecological linkages between aboveground and belowground biota. Science, 304, 1629-1633. 


\section{ChAPTER 3}

Beech trees fuel soil animal food webs via root-derived nitrogen

Sarah L. Zieger, Andrea Holczinger, Janine Sommer, Michaela Rath, Yakov Kuzyakov, Andrea Polle, Mark Maraun, Stefan Scheu

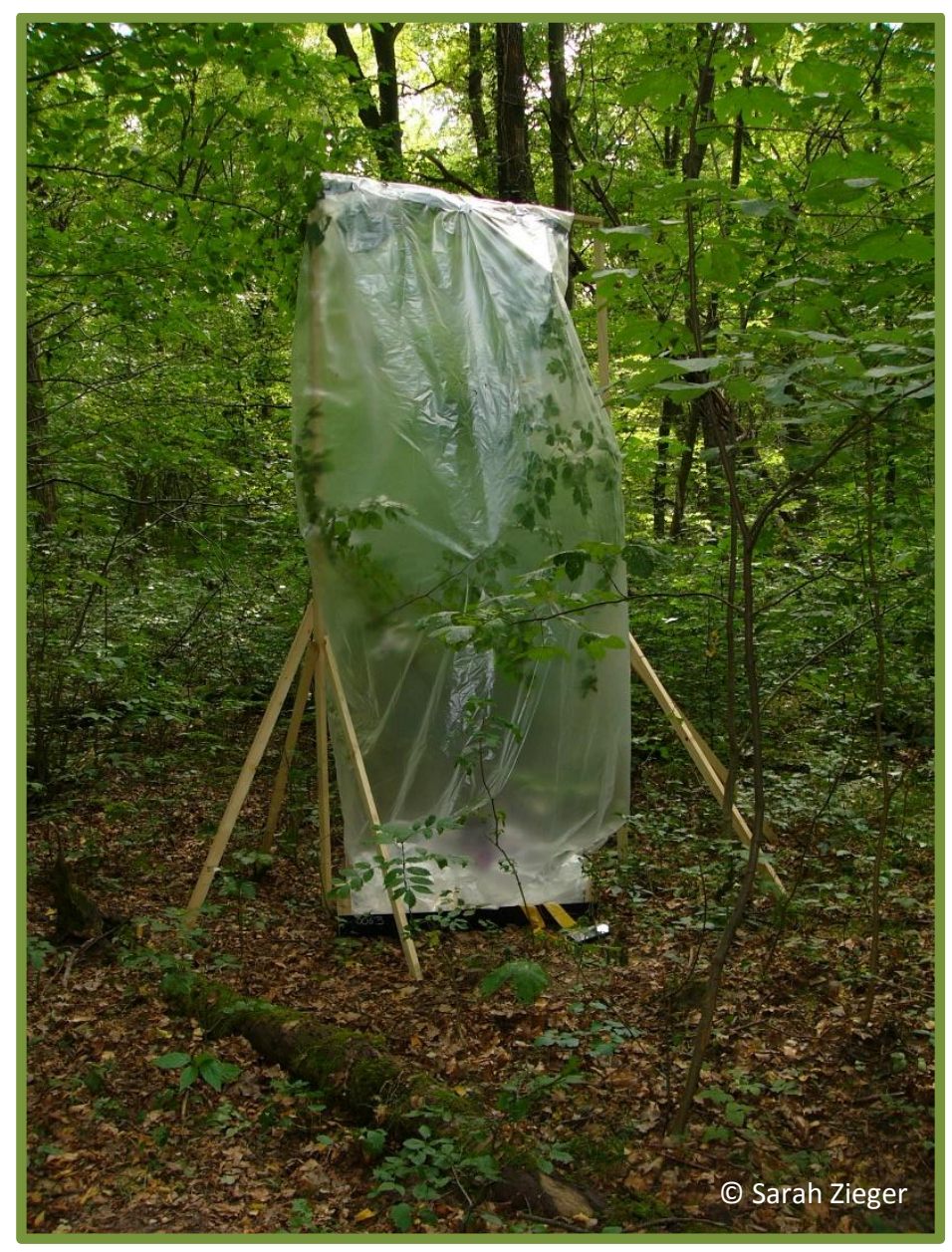




\begin{abstract}
Root-derived resources are receiving increased attention as basal resources for soil food webs. They predominantly function as carbon $(C)$ and energy resources for microbial metabolism in the rhizosphere, however, root-derived nitrogen $(\mathrm{N})$ may also be important. We explored both the role of root-derived $\mathrm{C}$ and $\mathrm{N}$ for the nutrition of soil animal species. Using ${ }^{13} \mathrm{C}$ and ${ }^{15} \mathrm{~N}$ labeling we followed in situ the flux of shoot-derived $\mathrm{C}$ and $\mathrm{N}$ into the soil animal food web of young beech (Fagus sylvatica) and ash (Fraxinus excelsior) trees, dominant species in European deciduous forests. Twenty days after labeling each of the studied soil animal species incorporated root-derived $\mathrm{N}$ whereas incorporation of root-derived $\mathrm{C}$ was only detected in the ash rhizosphere. More rootderived $\mathrm{N}$ was incorporated into soil animals in the beech as compared to the ash rhizosphere, contrasting higher ${ }^{15} \mathrm{~N}$ signatures in fine roots of ash as compared to beech. The results suggest that soil animal food webs not only rely on root $\mathrm{C}$ but also on root $\mathrm{N}$ with the contribution of root $\mathrm{N}$ to soil animal nutrition varying with tree species. This novel pathway of plant $\mathrm{N}$ highlights the importance of root-derived resources for soil animal food webs.
\end{abstract}

Keywords: Basal resources; Mycorrhiza; Pulse labeling; Rhizodeposits; Stable isotopes 


\section{Introduction}

The close interrelationship between the decomposer system and plants is mediated by leaf litter input and rhizodeposition (Wardle 2002). As up to $90 \%$ of net primary plant production is entering the soil as detritus (Cebrian 1999), litter has long been assumed to function as main food source of soil animals, but recent work has shown that other resources such as those derived from roots may be more important (Ruf et al. 2006; Pollierer et al. 2007; Eissfeller et al. 2013a). A variety of substances are released actively or passively from roots into the soil as rhizodeposits (Curl \& Truelove 1986; Jones et al. 2009). Rhizodeposits are divided into exudates, leakages, secretions, mucilage, mucigel and lysates (Rovira et al. 1979; Curl \& Truelove 1986), and include both carbon (C) and nitrogen $(\mathrm{N})$ containing compounds with $\mathrm{C}$ compounds being most important. $\mathrm{N}$ containing compounds are assumed to only be of significant importance in $\mathrm{N}$ fixing plants such as legumes (Ayres et al. 2007), but their role in other plants received little attention (Wichern et al. 2008). In addition to fueling microorganisms and fostering microbial biomass in the rhizosphere, rhizodeposits affect mutualistic and antagonistic interactions between soil microorganisms and plants (Bais et al. 2006).

Soil animal communities of deciduous forests are remarkably diverse (Anderson 1975; Schaefer 1991; Scheu 2005) and form complex food webs (Ehnes et al. 2014; Digel et al. 2014). These food webs span over a wide range of trophic levels including primary and secondary decomposers, and first, second and third order predators (Ponsard \& Arditi 2000; Scheu \& Falca 2000). Soil animals are affected by soil properties (Langenbruch et al. 2012), plant species (Scheu 2005; Eissfeller et al. 2013b) and soil microorganisms (Esperschütz et al. 2009; Koranda et al. 2011), with the latter two being mediated by rhizodeposits. Plant allocation of $\mathrm{C}$ to roots and into the rhizosphere received considerable attention in trees (Högberg et al. 2008; Subke et al. 2009; Kuzyakov \& Gavrichkova 2010), but $\mathrm{N}$ allocation to roots and into the rhizosphere has been investigated for herbaceous plants in particular legumes (Ayres et al. 2007; Wichern et al. 2008), whereas information on trees is lacking.

To investigate the flux of $\mathrm{C}$ and $\mathrm{N}$ from plants into the belowground system stable isotopes are increasingly used (Hertenberger \& Wanek 2004; Högberg et al. 2008). Adopting this approach we conducted a pulse labeling experiment in the field. By exposing trees to increased atmospheric ${ }^{13} \mathrm{CO}_{2}$ concentrations and by immersing leaves into $\mathrm{Ca}^{15} \mathrm{NO}_{3}$ solution we followed the flux of $\mathrm{C}$ and $\mathrm{N}$ into the soil animal food web. Using European beech (Fagus sylvatica) and common ash (Fraxinus excelsior) we examined if the effect of trees on the soil animal food web via rhizodeposits varies between tree species. Beech and ash were chosen as they are differing in nutrient allocation patterns and mycorrhiza types. Beech roots are associated with ectomycorrhizal (EM) while ash roots with arbuscular mycorrhizal (AM) fungi. The following hypotheses were investigated: (1) 
incorporation of root-derived $C$ into the soil animal food web varies between tree species and is more pronounced in EM beech than AM ash trees, and (2) root-derived $\mathrm{N}$ is of minor importance for soil animal nutrition and therefore incorporation into the soil animal food web varies little with tree species.

\section{Material and Methods}

\subsection{Study site}

The experiment was conducted in a temperate deciduous beech forest in the Hainich National Park (Thüringen, Germany) near Weberstedt $\left(51^{\circ} 05^{\prime} \mathrm{N}, 10^{\circ} 28^{\prime} \mathrm{E}\right)$ at $300 \mathrm{~m}$ asl. Mean annual precipitation is $670 \mathrm{~mm}$ and mean annual air temperature $7.5^{\circ} \mathrm{C}$. With 16,000 ha the Hainich National Park is the largest continuous deciduous forest in Germany and has been declared World Heritage Nature Site in June 2011. The forest predominantly consists of beech (F. sy/vatica) stocking on Luvisol developed on loess underlain by Triassic Shell Limestone. The forest floor is classified as mull-like moder and the mean thickness of the litter layer is $2.8 \pm 0.1 \mathrm{~cm}$ (Jacob et al. 2010; Langenbruch et al. 2014). The topsoil $(0-10 \mathrm{~cm})$ is rather acidic with a $\mathrm{pH}_{\mathrm{KCl}}$ of 3.3 (Mölder et al. 2006; Guckland et al. 2009).

\subsection{Labeling}

In August 2011 eight young trees, four beech and four ash, with $2.5-4.0 \mathrm{~m}$ in height and a minimum distance from each other of $5 \mathrm{~m}$ were selected for labeling; four trees, two beech and two ash, were identified as control. The young trees grew in the understory of a closed-canopy beech forest. Around each tree used for labeling an area of $1 \times 1 \mathrm{~m}$ was trenched by inserting polyethylene (PE) panels of a thickness of $3 \mathrm{~mm}$. The panels extended $10 \mathrm{~cm}$ into the soil and 10 $\mathrm{cm}$ above the soil surface to avoid immigration of animals.

For ${ }^{15} \mathrm{~N}$ labeling $36 \mathrm{~g} \mathrm{Ca}^{15} \mathrm{NO}_{3}$ (99.23 atom\% ${ }^{15} \mathrm{~N}$, Campro Scientific $\mathrm{GmbH}$, Berlin, Germany) was dissolved in $1200 \mathrm{ml}$ sterile water resulting in a $0.18 \mathrm{M}$ solution. Leaves were fed with this solution by installing three vials each with three leaves of beech or three leaflets of compound leaves of ash containing $12 \mathrm{ml} \mathrm{Ca}{ }^{15} \mathrm{NO}_{3}$ solution and incubated for $72 \mathrm{~h}$. To increase the uptake of $\mathrm{N}$, leaves were scratched prior to placement into the vials. To avoid leakage vials were covered with plastic film and enclosed into plastic bags.

For ${ }^{13} \mathrm{C}$ labeling trees were enclosed into plastic foil (thickness $0.08 \mathrm{~mm}$ ) fixed to wooden poles erected around the trees. Enclosed trees were labeled with ${ }^{13} \mathrm{CO}_{2}$ by adding $60 \mathrm{ml} 5 \mathrm{M} \mathrm{H}_{2} \mathrm{SO}_{4}$ to a solution containing $6.85 \mathrm{~g} \mathrm{Na}_{2}{ }^{13} \mathrm{CO}_{3}$ (99.0 atom\% ${ }^{13} \mathrm{C}$; Cambridge Isotope Laboratories, Tewksbury, USA) dissolved in $100 \mathrm{ml}$ distilled water. Air inside the enclosures was mixed using a ventilator. The labeling started at about 11 a.m. and lasted ca. 5 h. Thereafter, the plastic foil was removed. 
Twenty days after labeling the trees soil samples of a diameter of $20 \mathrm{~cm}$ to a depth of $10 \mathrm{~cm}$ were taken. Two samples spaced at least $10 \mathrm{~cm}$ were taken per tree. Soil animals were extracted by heat using a high-gradient canister method (Kempson et al. 1963) and stored in concentrated salt water at $-7^{\circ} \mathrm{C}$.

\subsection{Stable isotope analysis}

Four species of Oribatida (Steganacarus magnus Nicolet, 1855, Xenillus tegeocranus Hermann, 1804, Damaeus gracilipes Kulczynski, 1902, Damaeus riparius Nicolet, 1855) and one Isopoda (Porcellium conspersum Koch, 1841) were prepared for stable isotope analysis. For dual C and $\mathrm{N}$ stable isotope ratio analysis $100-300 \mu \mathrm{g}$ of animal tissue were transferred into tin capsules and dried at $40^{\circ} \mathrm{C}$ for $24 \mathrm{~h}$. Single individuals of large Oribatida were used, but for most Oribatida species several individuals had to be pooled. In Isopoda only the head was used to prevent including food material in the gut. Samples were analyzed with a system consisting of an elemental analyzer (NA 1500, Carlo Erba, Milan, Italy) and a mass spectrometer (MAT 251, Finnigan, Bremen, Germany). The computer controlled system allows on-line measurement of stable isotopes $\left({ }^{13} \mathrm{C}\right.$ and $\left.{ }^{15} \mathrm{~N}\right)$. Their abundance $\left(\delta_{\mathrm{x}}\right)$ is expressed using the $\delta$ notation as $\delta_{\mathrm{x}}[\% \mathrm{o}]=\left(\mathrm{R}_{\text {sample }}-\mathrm{R}_{\text {standard }}\right) / \mathrm{R}_{\text {standard }} \times 1000$ with $R_{\text {sample }}$ and $R_{\text {standard }}$ representing ${ }^{13} \mathrm{C} /{ }^{12} \mathrm{C}$ and ${ }^{15} \mathrm{~N} /{ }^{14} \mathrm{~N}$ ratios of samples and standard, respectively. For ${ }^{13} \mathrm{C}$ PD belemnite (PDB) and for ${ }^{15} \mathrm{~N}$ atmospheric nitrogen served as the primary standard. Acetanilide $\left(\mathrm{C}_{8} \mathrm{H}_{9} \mathrm{NO}\right.$, Merck, Darmstadt, Germany) was used for internal calibration.

\subsection{Calculation of $\Delta^{13} \mathrm{C}$ and $\Delta^{15} \mathrm{~N}$ values}

For analyzing the enrichment in ${ }^{15} \mathrm{~N}$ and ${ }^{13} \mathrm{C}$ of soil animals and fine roots we calculated the difference in delta values between animals and fine roots from labeled and unlabeled trees as $\Delta_{\text {element }}=\delta_{\text {label }}-\delta_{\text {control }}$ with $\Delta_{\text {element }}$ the $\Delta^{13} \mathrm{C}$ and $\Delta^{15} \mathrm{~N}$ values. Samples with mean $\Delta^{13} \mathrm{C}$ and $\Delta^{15} \mathrm{~N}$ in the range of two standard deviations of $\delta^{13} \mathrm{C}$ and $\delta^{15} \mathrm{~N}$ of control samples were assumed not to be enriched and set to zero.

\subsection{Statistical analysis}

Statistical analyses were performed using R v.3.1.3 (R Core Team 2015) and the 'nlme' package (Pinheiro et al. 2013). Stable isotope signatures of fine roots were used as covariate, but as variations in the signatures of the animals were not significantly related to isotope signatures of roots ( $C: F_{1,6}=0.64, P=0.455 ; N: F_{1,6}=0.34, P=0.579$ ) of the respective tree, the covariate was removed from the final model. $\Delta^{13} \mathrm{C}$ and $\Delta^{15} \mathrm{~N}$ values of fine roots were analyzed separately using one-factorial ANOVA to test for the effect of tree species on ${ }^{13} \mathrm{C}$ and ${ }^{15} \mathrm{~N}$ enrichment in fine roots. To increase homogeneity of variances $\Delta^{15} \mathrm{~N}$ and $\Delta^{13} \mathrm{C}$ values were log-transformed.

$\Delta^{15} \mathrm{~N}$ and $\Delta^{13} \mathrm{C}$ values of soil animals were analyzed separately using linear mixed effects models including a random effect of tree identity (tree ID) to allow testing for the effect of tree species and 
$\mathrm{C}$ and $\mathrm{N}$ incorporation into soil animal species avoiding pseudo-replication of soil animal species of the same tree. $\Delta^{15} \mathrm{~N}$ and $\Delta^{13} \mathrm{C}$ values were log-transformed to improve homogeneity of variance. Means given in figures are based on back-transformed means.

\section{Results}

Natural abundance ${ }^{15} \mathrm{~N}$ signatures in the five analyzed soil arthropod species increased in the order $P$. conspersum $(-2.40 \pm 0.35 \delta \%$ o $)<S$. magnus $(-2.19 \pm 0.51 \delta \%)<X$. tegeocranus $(-2.18 \pm 0.96$ $\delta \%$ o $<D$. gracilipes $\left(-0.69 \pm 0.14 \delta \%\right.$ ) $<D$. riparius $\left(-0.57 \pm 0.67 \delta \%\right.$ ). Respective values for $\delta^{13} \mathrm{C}$ were $-25.39 \pm 0.66,-20.8 \pm 0.93,-24.26 \pm 0.89,-25.26 \pm 0.49,-25.61 \pm 1.06$.

${ }^{13} \mathrm{C}$ enrichment in soil animal species (D. gracilipes, $D$. riparius, $P$. conspersum, S. magnus, $X$. tegeocranus) generally did not differ significantly $\left(F_{4,26}=1.21, P=0.33\right) . \Delta^{13} \mathrm{C}$ values of soil animals differed between tree species $\left(F_{1,6}=20.56, P=0.004\right)$; soil animals under beech generally were not enriched in ${ }^{13} \mathrm{C}$, whereas under ash they were slightly enriched but the enrichment varied strongly (0.56 $\pm 6.21 \%$; Fig. 3.1). $\Delta^{13} \mathrm{C}$ values of fine roots of beech and ash did not differ significantly, although they were higher in ash $\left(36.57 \pm 35.15 \%\right.$ o) as compared to beech $\left(19.36 \pm 25.43 \%\right.$; $F_{1,6}=$ $1.32, \mathrm{P}=0.295)$.

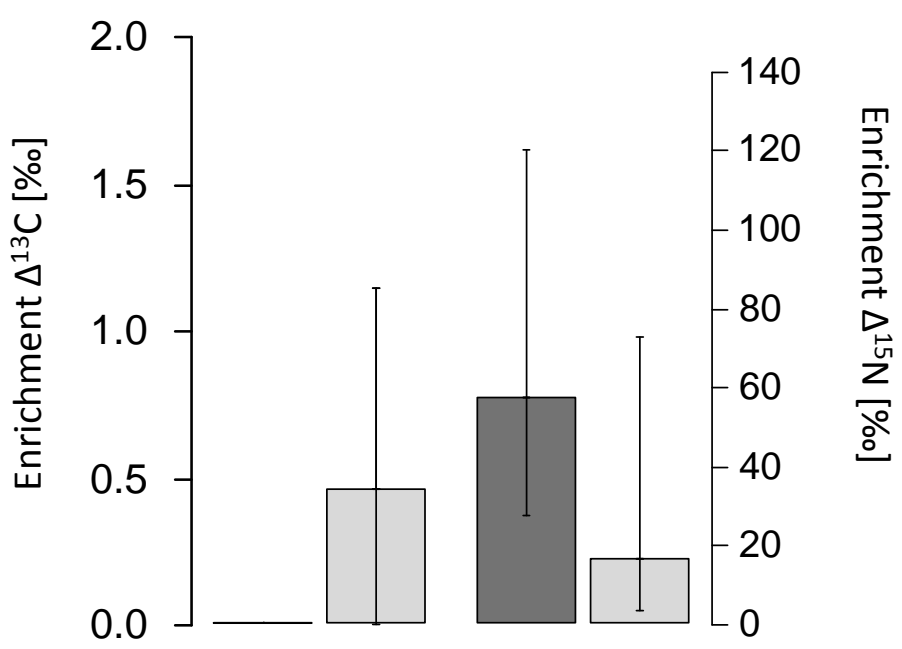

Fig. 3.1: Enrichment in $\Delta^{13} \mathrm{C}$ and $\Delta^{15} \mathrm{~N}$ in soil animals under beech (dark grey) and ash (light grey) 20 days after labeling with ${ }^{13} \mathrm{CO}_{2}$ and $\mathrm{Ca}^{15} \mathrm{NO}_{3}$. Means and standard deviation are back-transformed values of log-transformed data.

In contrast to ${ }^{13} \mathrm{C}, \Delta^{15} \mathrm{~N}$ values significantly differed between soil animals $\left(\mathrm{F}_{4,26}=3.32, \mathrm{P}=0.025\right)$ and declined in the order $P$. conspersum $>X$. tegeocranus $>D$. gracilipes $>S$. magnus $>D$. riparius (Fig. 3.2). Again, in contrast to ${ }^{13} \mathrm{C}, \Delta^{15} \mathrm{~N}$ values of soil animals varied markedly between tree species $\left(F_{1,6}=13.85, P=0.010\right)$; on average soil animals under beech $(74.65 \pm 60.86 \%$ ) were more enriched than those under ash $\left(43.77 \pm 66.24 \%\right.$ o). $\Delta^{15} \mathrm{~N}$ values of fine roots of beech and ash also significantly differed, but contrary to animal signatures $\Delta^{15} \mathrm{~N}$ values in ash fine roots $(727.56 \pm 727.99 \%$ o) markedly exceeded those in beech fine roots $\left(62.19 \pm 40.37 \%\right.$; $\left.F_{1,6}=9.98, P=0.020\right)$. 


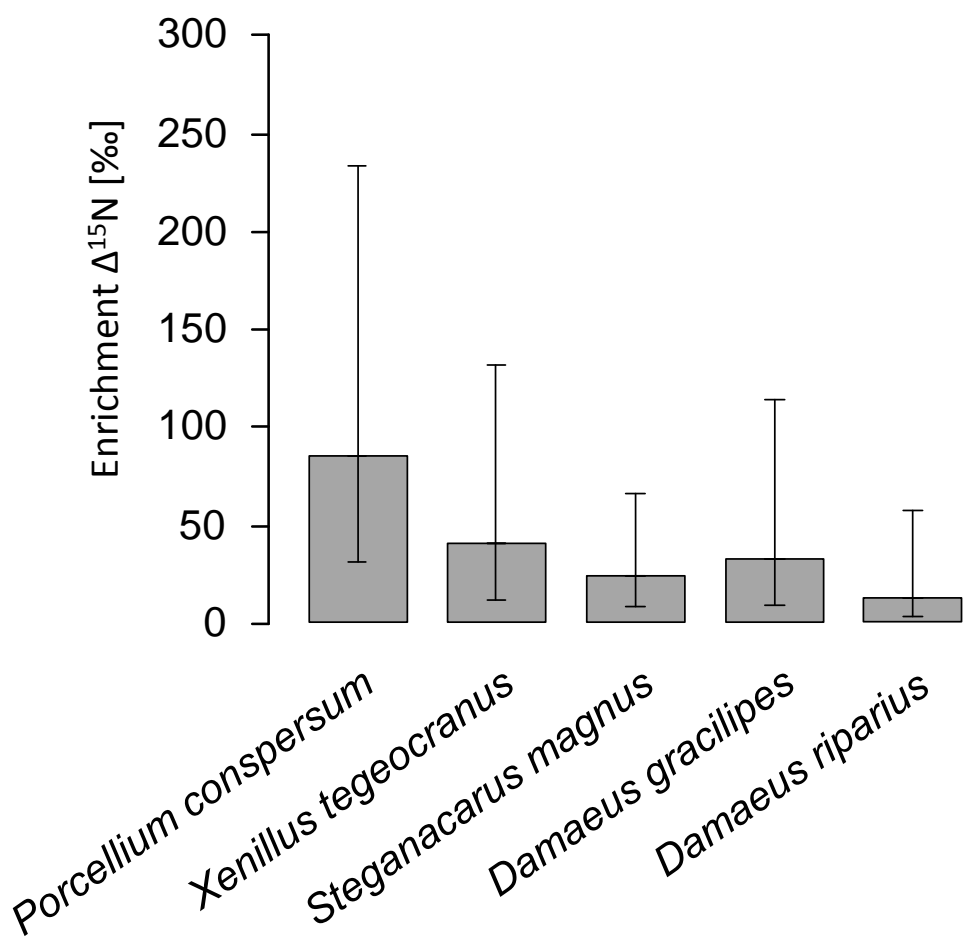

Fig. 3.2: Enrichment in $\Delta^{15} \mathrm{~N}$ in soil animals 20 days after labeling with ${ }^{13} \mathrm{CO}_{2}$ and $\mathrm{Ca}^{15} \mathrm{NO}_{3}$. Means and standard deviation are back-transformed values of log-transformed data.

\section{Discussion}

\subsection{Incorporation of root carbon}

Contrary to our expectations soil animals incorporated little root-derived C. As it is well established that soil animals heavily rely on root-derived C (Ruf et al. 2006; Pollierer et al. 2007; Eissfeller et al. 2013a), the experimental setup and the amount of ${ }^{13} \mathrm{C}$ for labeling may have been responsible for this result. Compared to most previous studies we used an in situ approach by labeling understory trees in the field. Under these conditions, a number of factors may have contributed to low uptake of ${ }^{13} \mathrm{CO}_{2}$ by the trees, most importantly shading by mature trees resulting in low photosynthetic activity. Further, the amount of label and the duration of the labeling period may not have been sufficient to allow tracing the signal in soil animals as typically only 2-4 \% of the C fixed by plants is transferred into the soil (Jones et al. 2004). Also, heterogeneously distributed roots, typical for field growing trees, and a mismatch between the localities where rhizodeposits were released and where soil animals were captured may have contributed to the low incorporation of root $\mathrm{C}$ into soil animals.

Incorporation of root $\mathrm{C}$ was very low but in the rhizosphere of ash exceeded that in beech where no incorporation was detectable suggesting that our first hypothesis has to be rejected. However, this conclusion presumably may be premature as incorporation of root $\mathrm{C}$ may have been too low to 
detect differences. Nevertheless, the results suggest that incorporation of root $\mathrm{C}$ in tree species differs depending on the type of mycorrhizal association. The low incorporation under beech trees is surprising as extramatrical hyphae of EM fungi associated with these trees enhance carbon translocation into soil (Högberg et al. 2008; Esperschütz et al. 2009; Cairney 2012) and the soil food web (Cesarz et al. 2013). Also, seasonal effects might have contributed to the observed pattern as the experiment was conducted in late summer when ash trees enhance allocation of assimilates to roots (R. Thoms, unpubl. data).

\subsection{Incorporation of root nitrogen}

In contrast to our second hypothesis soil animals were markedly enriched in ${ }^{15} \mathrm{~N}$ demonstrating that root-derived $\mathrm{N}$ forms part of the resources fueling soil animal food webs. Presumably, via rhizodeposition $\mathrm{N}$ compounds entered the rhizosphere and the surrounding soil (Curl \& Truelove 1986; Merbach et al. 1999; Bais et al. 2006). Except for legumes this has been shown mainly for grasses (Hertenberger \& Wanek 2004; Wichern et al. 2008) but not for trees. Root-derived N compounds are likely to be taken up quickly by microorganisms, and via microbivorous soil animals they are incorporated into the soil animal food web. However, feeding on living or dead roots or rhizosphere microorganisms may also contribute to the flux of root $\mathrm{N}$ into soil animal food webs as some detritivores occasionally also feed on roots (Endlweber et al. 2009). In the present experiment nitrogen assimilated by leaves was transferred to the roots (J. Sommer, unpubl. data), which is in agreement with results of an earlier study on beech (Brumme et al. 1992). As indicated by the ${ }^{15} \mathrm{~N}$ incorporation into soil animals, part of the $\mathrm{N}$ transferred to roots was incorporated into the soil animal food web.

Notably, incorporation of root-derived $\mathrm{N}$ into soil animals varied between species and decreased in the order $P$. conspersum $>X$. tegeocranus $>D$. gracilipes $>S$. magnus $>D$. riparius. According to natural variations in stable isotope signatures in the present experiment $P$. conspersum, $X$. tegeocranus and $S$. magnus function as primary decomposers while $D$. gracilipes and $D$. riparius function as secondary decomposers which conforms to previous studies (Scheu \& Falca 2000; Schneider et al. 2004a; Maraun et al. 2011). Incorporation of root-derived $\mathrm{N}$ into these species was unlikely due to feeding on roots as ${ }^{15} \mathrm{~N}$ signatures of fine roots were not correlated with those of animals (see Material and Methods). Rather, root-derived $\mathrm{N}$ likely was taken up by microorganisms and thereby also transferred into leaf litter (Lummer et al. 2012) and, via feeding on litter, it was incorporated into decomposer animals (Rihani et al. 1995; David \& Gillon 2002). In secondary decomposers root-derived $\mathrm{N}$ likely was incorporated by feeding on microorganisms in particular fungal hyphae. Further, in certain soil mite species such as $S$. magnus root-derived $\mathrm{N}$ may have been incorporated via feeding on microbivorous or root-feeding nematodes (Heidemann et al. 2011). 
This suggests that root-derived $\mathrm{N}$ propagates quickly into soil decomposers with nematodes likely contributing to this process.

Each of the studied soil animal species incorporated more ${ }^{15} \mathrm{~N}$ under beech as compared to ash and this contrasted the concentrations of ${ }^{15} \mathrm{~N}$ in fine roots of beech and ash. This suggests that rhizodeposition in beech including $\mathrm{N}$ compounds exceeds that in ash which conforms to recent findings (Holzwarth et al. 2011; Cesarz et al. 2013). Supporting this conclusion J. Sommer (unpubl. data) found the transfer of ${ }^{15} \mathrm{~N}$ into rhizosphere soil under beech to exceed that under ash trees. As shown for carbon, EM fungi may have contributed to higher transfer of root-derived $\mathrm{N}$ into the soil under beech as compared to ash (colonized by AM fungi) (Högberg et al. 2008; Cairney 2012). Notably and in contrast to the view that $\mathrm{N}$ is transferred only from mycorrhiza to roots, in our experiment mycorrhized root tips of beech were enriched in ${ }^{15} \mathrm{~N}$ (M. Rath, unpubl. data) indicating that nitrogen is also transferred from roots to mycorrhiza. This supports our conclusion that EM fungi in part fostered the transfer of $\mathrm{N}$ into the soil animal food web via fungivorous species feeding on the extramatrical mycelium of EM fungi.

\subsection{Conclusion}

Incorporation of root-derived C into soil animals was low in this experiment, but this likely was due to low uptake of ${ }^{13} \mathrm{CO}_{2}$ by the trees and low transfer of ${ }^{13} \mathrm{C}$ into the rhizosphere. Low ${ }^{13} \mathrm{C}$ addition may have contributed to these findings. Surprisingly, root-derived $\mathrm{N}$ was incorporated into soil animals and this was more pronounced under beech associated with EM as compared to ash associated with AM. The results therefore support recent findings that the effect of EM beech on rhizosphere microorganisms exceeds that of AM ash (Cesarz et al. 2013). Notably, all animal species studied incorporated root-derived $\mathrm{N}$ with the incorporation not varying significantly with animal species or trophic group, suggesting that their resources including EM fungi, saprotrophic microorganisms and nematodes, were labeled to a similar extent. 


\section{Acknowledgments}

This project was funded by the German Research Foundation (GRK1086/2, project A04). We are grateful to the administration of Hainich National Park for permission to conduct the study in the Hainich National Park. We thank Christian Bluhm, Dieter Nünchert and Bernd Messerschmidt for help in preparing and inserting PE-panels, installing ventilators and Ronny Thoms for help in erecting wooden poles around the trees. Christian Bluhm and Benjamin Klein for help in the destructive sampling of the experiment and the Kompetenzzentrum Stabile Isotope (KOSI, University of Göttingen) for measuring stable isotopes.

\section{References}

Anderson, J.M. (1975) The enigma of soil animal diversity. Progress in Soil Zoology Proceedings of the Fifth International Colloquium of Soil Zoology (ed J. Vaněk), pp. 51-58. Academia, Prague.

Ayres, E., Dromph, K.M., Cook, R., Ostle, N. \& Bardgett, R.D. (2007) The influence of below-ground herbivory and defoliation of a legume on nitrogen transfer to neighbouring plants. Functional Ecology, 21, 256-263.

Bais, H.P., Weir, T.L., Perry, L.G., Gilroy, S. \& Vivanco, J.M. (2006) The role of root exudates in rhizosphere interactions with plants and other organisms. Annual Review of Plant Biology, 57, 233-266.

Brumme, R., Leimcke, U. \& Matzner, E. (1992) Interception and uptake of NH4 and NO3 from wet deposition by above-ground parts of young beech (Fagus silvatica L.) trees. Plant and soil, 142, 273-279.

Cairney, J.W.G. (2012) Extramatrical mycelia of ectomycorrhizal fungi as moderators of carbon dynamics in forest soil. Soil Biology \& Biochemistry, 47, 198-208.

Cebrian, J. (1999) Patterns in the fate of production in plant communities. The American Naturalist, 154, 449-468.

Cesarz, S., Fender, A.-C., Beyer, F., Valtanen, K., Pfeiffer, B., Gansert, D., Hertel, D., Polle, A., Daniel, R., Leuschner, C. \& Scheu, S. (2013) Roots from beech (Fagus sy/vatica L.) and ash (Fraxinus excelsior L.) differentially affect soil microorganisms and carbon dynamics. Soil Biology \& Biochemistry, 61, 23-32.

Curl, E.A. \& Truelove, B. (1986) The Rhizosphere. Springer-Verlag, Berlin/Heidelberg.

David, J.-F. \& Gillon, D. (2002) Annual feeding rate of the millipede Glomeris marginata on holm oak (Quercus ilex) leaf litter under Mediterranean conditions. Pedobiologia, 46, 42-52.

Digel, C., Curtsdotter, A., Riede, J., Klarner, B. \& Brose, U. (2014) Unravelling the complex structure of forest soil food webs: Higher omnivory and more trophic levels. Oikos, 123, 1157-1172.

Ehnes, R.B., Pollierer, M.M., Erdmann, G., Klarner, B., Eitzinger, B., Digel, C., Ott, D., Maraun, M., Scheu, S. \& Brose, U. (2014) Lack of energetic equivalence in forest soil invertebrates. Ecology, 95, 527-537.

Eissfeller, V., Beyer, F., Valtanen, K., Hertel, D., Maraun, M., Polle, A. \& Scheu, S. (2013a) Incorporation of plant carbon and microbial nitrogen into the rhizosphere food web of beech and ash. Soil Biology \& Biochemistry, 62, 76-81. 
Eissfeller, V., Langenbruch, C., Jacob, A., Maraun, M. \& Scheu, S. (2013b) Tree identity surpasses tree diversity in affecting the community structure of oribatid mites (Oribatida) of deciduous temperate forests. Soil Biology \& Biochemistry, 63, 154-162.

Endlweber, K., Ruess, L.R. \& Scheu, S. (2009) Collembola switch diet in presence of plant roots thereby functioning as herbivores. Soil Biology \& Biochemistry, 41, 1151-1154.

Esperschütz, J., Buegger, F., Winkler, J.B., Munch, J.C., Schloter, M. \& Gattinger, A. (2009) Microbial response to exudates in the rhizosphere of young beech trees (Fagus sylvatica L.) after dormancy. Soil Biology \& Biochemistry, 41, 1976-1985.

Guckland, A., Jacob, M., Flessa, H., Thomas, F.M. \& Leuschner, C. (2009) Acidity, nutrient stocks, and organic-matter content in soils of a temperate deciduous forest with different abundance of European beech (Fagus sylvatica L.). Journal of Plant Nutrition and Soil Science, 172, 500511.

Heidemann, K., Scheu, S., Ruess, L.R. \& Maraun, M. (2011) Molecular detection of nematode predation and scavenging in oribatid mites: Laboratory and field experiments. Soil Biology \& Biochemistry, 43, 2229-2236.

Hertenberger, G. \& Wanek, W. (2004) Evaluation of methods to measure differential $15 \mathrm{~N}$ labeling of soil and root $\mathrm{N}$ pools for studies of root exudation. Rapid communications in mass spectrometry : RCM , 18, 2415-2425.

Högberg, P., Högberg, M.N., Göttlicher, S.G., Betson, N.R., Keel, S.G., Metcalfe, D.B., Campbell, C.D., Schindlbacher, A., Hurry, V., Lundmark, T., Linder, S. \& Näsholm, T. (2008) High temporal resolution tracing of photosynthate carbon from the tree canopy to forest soil microorganisms. New Phytologist, 177, 220-228.

Holzwarth, F.M., Daenner, M. \& Flessa, H. (2011) Effects of beech and ash on small-scale variation of soil acidity and nutrient stocks in a mixed deciduous forest. Journal of Plant Nutrition and Soil Science, 174, 799-808.

Jacob, M., Viedenz, K., Polle, A. \& Thomas, F.M. (2010) Leaf litter decomposition in temperate deciduous forest stands with a decreasing fraction of beech (Fagus sy/vatica). Oecologia, 164, 1083-1094.

Jones, D.L., Hodge, A. \& Kuzyakov, Y. (2004) Plant and mycorrhizal regulation of rhizodeposition. New Phytologist, 163, 459-480.

Jones, D.L., Nguyen, C. \& Finlay, R.D. (2009) Carbon flow in the rhizosphere: Carbon trading at the soil-root interface. Plant and Soil, 321, 5-33.

Kempson, D., Lloyd, M. \& Ghelardi, R. (1963) A new extractor for woodland litter. Pedobiologia, 3, $1-21$.

Koranda, M., Schnecker, J., Kaiser, C., Fuchslueger, L., Kitzler, B., Stange, C.F., Sessitsch, A., Zechmeister-Boltenstern, S. \& Richter, A. (2011) Microbial processes and community composition in the rhizosphere of European beech - The influence of plant $\mathrm{C}$ exudates. Soil Biology \& Biochemistry, 43, 551-558.

Kuzyakov, Y. \& Gavrichkova, O. (2010) Time lag between photosynthesis and carbon dioxide efflux from soil: a review of mechanisms and controls. Global Change Biology, 16, 3386-3406.

Langenbruch, C., Helfrich, M. \& Flessa, H. (2012) Effects of beech (Fagus sylvatica), ash (Fraxinus excelsior) and lime (Tilia spec.) on soil chemical properties in a mixed deciduous forest. Plant and Soil, 352, 389-403. 
Langenbruch, C., Helfrich, M., Joergensen, R.G., Gordon, J. \& Flessa, H. (2014) Partitioning of carbon and nitrogen during decomposition of $13 \mathrm{C} 15 \mathrm{~N}$-labeled beech and ash leaf litter. Journal of Plant Nutrition and Soil Science, 177, 178-188.

Lummer, D., Scheu, S. \& Butenschoen, O. (2012) Connecting litter quality, microbial community and nitrogen transfer mechanisms in decomposing litter mixtures. Oikos, 121, 1649-1655.

Maraun, M., Erdmann, G., Fischer, B.M., Pollierer, M.M., Norton, R.A., Schneider, K. \& Scheu, S. (2011) Stable isotopes revisited: Their use and limits for oribatid mite trophic ecology. Soil Biology \& Biochemistry, 43, 877-882.

Merbach, W., Mirus, E., Knof, G., Remus, R., Ruppel, S., Russow, R., Gransee, A. \& Schulze, J. (1999) Release of carbon and nitrogen compounds by plant roots and their possible ecological importance. Journal of Plant Nutrition and Soil Science, 162, 373-383.

Mölder, A., Bernhardt-Römermann, M. \& Schmidt, W. (2006) Forest ecosystem research in Hainich National Park (Thuringia): first results on flora and vegetation in stands with contrasting tree species diversity. Waldoekologie online, 3, 83-99.

Pinheiro, J., Bates, D., DebRoy, S. \& Sarkar, D. (2013) nlme: Linear and Nonlinear Mixed Effects Models. R package ver. 3.1-120, R package.

Pollierer, M.M., Langel, R., Körner, C., Maraun, M. \& Scheu, S. (2007) The underestimated importance of belowground carbon input for forest soil animal food webs. Ecology Letters, 10, 729-736.

Ponsard, S. \& Arditi, R. (2000) What can stable isotopes ( $\delta 15 \mathrm{~N}$ and $\delta 13 \mathrm{C}$ ) tell about the food web of soil macro-invertebrates? Ecology, 81, 852-864.

Rihani, M., Cancela da Fonseca, J.P. \& Kiffer, E. (1995) Decomposition of beech leaf litter by microflora and mesofauna. II. Food preferences and action of oribatid mites on different substrates. European Journal of Soil Biology, 31, 67-79.

Rovira, A.D., Foster, R.C. \& Martin, J.K. (1979) Note on terminology: origin, nature and nomenclature of the organic materials in the rhizosphere. The Soil-Root Interface (ed J.L. Harley), pp. 1-4. Elsevier.

Ruf, A., Kuzyakov, Y. \& Lopatovskaya, O. (2006) Carbon fluxes in soil food webs of increasing complexity revealed by $14 \mathrm{C}$ labelling and $13 \mathrm{C}$ natural abundance. Soil Biology \& Biochemistry, 38, 2390-2400.

Schaefer, M. (1991) The animal community: diversity and resources. Temperate Deciduous Forests (Ecosystems of the World) (eds E. Rohrig \& B. Ulrich), pp. 51-120. Elsevier, Amsterdam.

Scheu, S. (2005) Linkages Between Tree Diversity, Soil Fauna and Ecosystem Processes. Forest Diversity and Function, Ecological Studies 176, 167th ed (eds M. Scherer-Lorenzen, C. Körner \& E.-D. Schulze), pp. 211-233. Springer-Verlag, Berlin/Heidelberg.

Scheu, S. \& Falca, M. (2000) The soil food web of two beech forests (Fagus sylvatica) of contrasting humus type: stable isotope analysis of a macro- and a mesofauna-dominated community. Oecologia, 123, 285-296.

Schneider, K., Migge, S., Norton, R.A., Scheu, S., Langel, R., Reineking, A. \& Maraun, M. (2004) Trophic niche differentiation in soil microarthropods (Oribatida, Acari): evidence from stable isotope ratios (15N/14N). Soil Biology \& Biochemistry, 36, 1769-1774.

Subke, J.-A., Vallack, H.W., Magnusson, T., Keel, S.G., Metcalfe, D.B., Högberg, P. \& Ineson, P. (2009) Short-term dynamics of abiotic and biotic soil $13 \mathrm{CO} 2$ effluxes after in situ $13 \mathrm{CO} 2$ pulse labelling of a boreal pine forest. New Phytologist, 183, 349-357. 
Wardle, D.A. (2002) Communities and Ecosystems: Linking the Aboveground and Belowground Components. Princeton University Press, Princeton, NJ.

Wichern, F., Eberhardt, E., Mayer, J., Joergensen, R.G. \& Müller, T. (2008) Nitrogen rhizodeposition in agricultural crops: Methods, estimates and future prospects. Soil Biology \& Biochemistry, 40, 30-48. 


\section{Chapter 4}

Root-derived carbon and nitrogen from beech and ash trees differentially fuel soil animal food webs

Sarah L. Zieger, Stefan Scheu

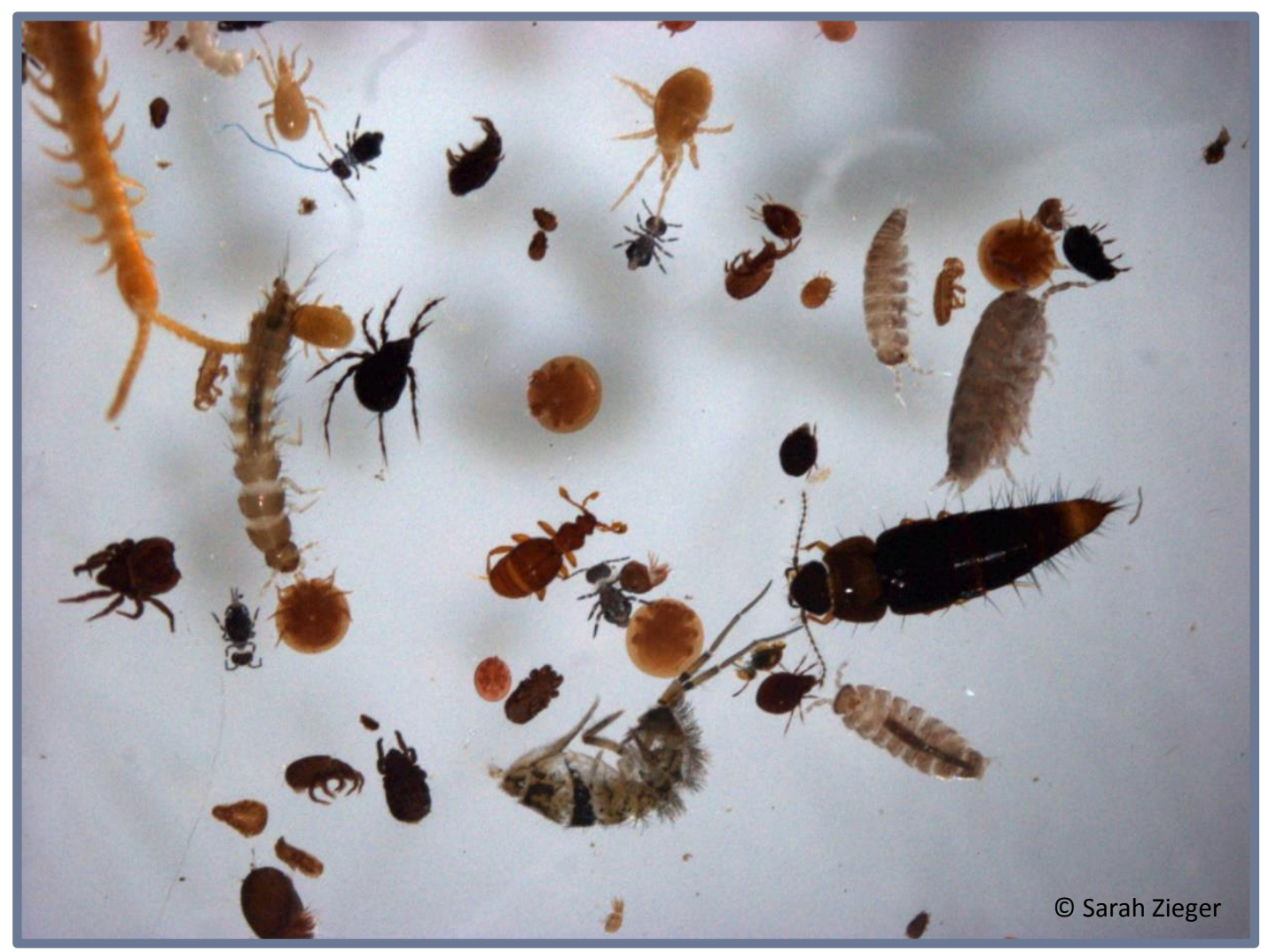




\begin{abstract}
Evidence is increasing that soil animal food webs are fueled by root-derived carbon (C) and also by root-derived nitrogen $(\mathrm{N})$. Functioning as link between the above- and belowground system trees and their identity are important factors structuring soil animal communities. A pulse labeling experiment using ${ }^{15} \mathrm{~N}$ and ${ }^{13} \mathrm{C}$ was conducted by exposing beech (Fagus sy/vatica) and ash (Fraxinus excelsior) seedlings to ${ }^{13} \mathrm{CO}_{2}$ enriched atmosphere and tree leaves to ${ }^{15} \mathrm{~N}$ ammonium chloride solution in a plant growth chamber under controlled conditions for $72 \mathrm{~h}$. C and $\mathrm{N}$ fluxes into the soil animal food web of beech, associated with ectomycorrhizal fungi (EMF), and ash, associated with arbuscular mycorrhizal fungi (AMF), were investigated at two sampling dates ( 5 and 20 days after labeling). All of the soil animal taxa studied incorporated root-derived $\mathrm{C}$, while root-derived $\mathrm{N}$ was only incorporated into certain taxa. Tree species identity strongly affected $\mathrm{C}$ and $\mathrm{N}$ incorporation with the incorporation in the beech rhizosphere generally exceeding that in the ash rhizosphere. Incorporation differed little 5 and 20 days after labeling indicating that both $\mathrm{C}$ and $\mathrm{N}$ are incorporated quickly into soil animals and are used for tissue formation. Our results suggest that energy and nutrient fluxes in soil food webs depend on the identity of tree species with the differences being associated with different types of mycorrhiza. Further research is needed to prove the generality of these findings and to quantify the flux of $\mathrm{C}$ and $\mathrm{N}$ into soil food webs of forests and other terrestrial ecosystems.
\end{abstract}

Keywords: Collembola; Gamasida; Mycorrhiza; Oribatida; Pulse labeling; Rhizosphere; Soil fauna; Stable isotopes 


\section{Introduction}

Soil animal communities of deciduous forest form complex food webs (Ehnes et al. 2014; Digel et al. 2014) of high species diversity (Anderson 1975; Schaefer 1990). They comprise a wide spectrum of trophic levels including primary and secondary decomposers, and first, second and third order predators (Ponsard \& Arditi 2000; Scheu \& Falca 2000). Soil food webs are connected with the aboveground system via leaf litter input and root-derived resources. Recently, evidence is increasing that the importance of root-derived carbon (C) for fueling soil animal food webs outweighs that of leaf litter C (Ruf et al. 2006; Pollierer et al. 2007; Gilbert et al. 2014). Further, it has been suggested recently that also root-derived nitrogen $(\mathrm{N})$ contributes to the nutrition of soil animals (S. Zieger, unpubl. data). Root-derived $\mathrm{C}$ and $\mathrm{N}$ enter the soil animal food web via living or dead roots, but also via root exudates (Högberg et al. 2008; Kuzyakov \& Gavrichkova 2010). Root exudates consist of low molecular weight carbohydrates and therefore are easier available for soil microorganisms than recalcitrant litter C (van Hees et al. 2005; Glanville et al. 2012). Besides the release of $\mathrm{C}$ compounds such as sugars, compounds containing both $\mathrm{C}$ and $\mathrm{N}$ are released by roots such as amino acids and peptides (Bais et al. 2006). For wheat, but in particular for legumes, it has been shown that root-derived $\mathrm{N}$ is transferred into the soil, soil microorganisms and neighboring plants (Wichern et al. 2008).

Rhizodeposits, their transformed products and the elements they contain enter the soil food web via bacteria and fungi, and are transferred to higher trophic levels via bacterial and fungal feeding soil animals and via predators high up into the food web (Ruf et al. 2006; Pollierer et al. 2007; Lemanski \& Scheu 2014b). Mycorrhizal and saprotrophic fungi dominate the fungal community of forest soils and play a central role in C and $\mathrm{N}$ cycling (Leake et al. 2002). Rhizosphere $\mathrm{C}$ and $\mathrm{N}$ is rapidly taken up by bacteria and fungi with fungi playing a more important role than previously assumed (Johnson et al. 2002; Lemanski \& Scheu 2014a). For soil invertebrates, such as Collembola and Oribatida dominating the soil mesofauna in soils, hyphae of saprotrophic and mycorrhizal fungi act as major source of $\mathrm{C}$ and nutrients and their role in animal nutrition likely outweighs that of leaf litter (Leake et al. 2002; Pollierer et al. 2007; Eissfeller et al. 2013a).

One of the most important factors structuring soil animal communities in forests is tree species identity (Cesarz et al. 2013; Tedersoo et al. 2015). In deciduous forests, tree species associated with ectomycorrhizal fungi (EMF) and arbuscular mycorrhizal fungi (AMF) co-occur. Both mycorrhizal forms release substantial amounts of $\mathrm{C}$ into the rhizosphere, but the flux may differ between EMF and AMF (Phillips \& Fahey 2005, 2006). Indeed, it has been shown, that beech (Fagus sy/vatica) associated with EMF more intensively affects the rhizosphere as compared to ash (Fraxinus excelsior) associated with AMF (Cesarz et al. 2013), but the impact of these differences on soil animal nutrition remains elusive. 
Due to the small size of most soil animal species and the opaqueness of the soil system, uncovering food relationships via direct observations is limited calling for alternative approaches such as the analysis of natural variations in stable isotope ratios, lipid analysis and molecular gut content analysis (Brose \& Scheu 2014). However, to uncover the flux of $C$ and nutrients into soil animal food webs experimental studies using labeling approaches are needed (Gannes et al. 1997; Pollierer et al. 2007; Eissfeller et al. 2013a; Hyodo 2015). Using this approach we investigated the flux of root-derived $\mathrm{C}$ and $\mathrm{N}$ by pulse labeling plants with ${ }^{13} \mathrm{C}$ and ${ }^{15} \mathrm{~N}$ by exposing plant shoots to ${ }^{13} \mathrm{CO}_{2}$ enriched atmosphere and by immersing plant leaves to ${ }^{15} \mathrm{NH}_{4} \mathrm{Cl}$ solution (Wichern et al. 2008). Incorporation of ${ }^{13} \mathrm{C}$ and ${ }^{15} \mathrm{~N}$ into soil animal taxa was followed for 5 and 20 days allowing to identify the flux of root-derived $\mathrm{C}$ and $\mathrm{N}$ into the soil food web. Comparing the flux of $\mathrm{C}$ and $\mathrm{N}$ into soil animals in the rhizosphere of beech and ash, the role of mycorrhiza type for soil animal nutrition of deciduous forests was investigated.

We hypothesized that (1) incorporation of root-derived $\mathrm{C}$ and $\mathrm{N}$ into soil animal taxa varies with tree species associated with either EMF (beech) or AMF (ash), with the incorporation in EMF beech exceeding that in AMF ash, and (2) the incorporation rapidly declines with time due to fast turnover rates of root associated microorganisms and microorganism based $\mathrm{C}$ and $\mathrm{N}$ pools.

\section{Material and Methods}

\subsection{Experimental setup}

In May 201240 beech and 40 ash seedlings were excavated including intact rhizosphere soil and litter from the Göttinger Wald (Reyershausen), Göttingen (51³5'15.39"N 958'57.95"E, 362 AMSL). The Göttinger Wald is a 130-145 year old beech forest interspersed with maple and ash. The main soil type is Leptosol with mull humus on limestone and an averaged pH of 5.3 (Schaefer 1990). Individual seedlings with undisturbed soil were transferred into planting pots of $23 \times 23 \mathrm{~cm}$ and a depth of $26 \mathrm{~cm}$. Seedlings were about $1 \mathrm{~m}$ in height (ranging between 73 and $177 \mathrm{~cm}$ ). First, they were kept in a shaded area under the canopy of mature beech trees and then transferred to an outdoor greenhouse. The seedlings were irrigated regularly and herbs were removed by cutting the shoots at soil surface level.

\subsection{Labeling}

The seedlings were labeled in four batches of ten seedlings each, beginning with ten ash seedlings. For ${ }^{15} \mathrm{~N}$ labeling 98 atom\% ${ }^{15} \mathrm{~N}$ ammonium-chloride (Campro Scientific, Berlin, Germany) was used. Control seedlings were treated with unlabeled ammonium-chloride (Merck, Darmstadt, Germany). In both treatments a $20 \mathrm{mMol}$ solution was mixed with sterile distilled water stored at $20^{\circ} \mathrm{C}$ until usage. Three times three leaves of beech and three times three leaflets of ash were put in $20 \mathrm{ml}$ scintillation vials containing ammonium-chloride solution for $72 \mathrm{~h}$. To increase label uptake, 
the leaf surface was roughened with sand paper (Basic Korn 240, LUX, Wermelskirchen, Germany). The vials were enclosed by using parafilm and placed into plastic bags. To avoid contamination of the soil by leaching of label, planting pots were covered with plastic bags tightened at the stem of the seedlings with Terostat (Teroson Terostat-VII, Henkel, Düsseldorf, Germany). After labeling, leaves and leaflets used for labeling were cut and removed.

After immersion of the leaves into the ${ }^{15} \mathrm{~N}$ labeling solution, the seedlings were transferred to a plant growth chamber. Conditions in the chamber were kept at $1,013 \mathrm{hPa}, 20^{\circ} \mathrm{C}$ and $70 \%$ relative humidity, light intensity was $420 \mu \mathrm{E}$ for $16 \mathrm{~h} /$ day. Planting pots were enwrapped in plastic bags tightened at the stem of the seedlings with Terostat. An irrigation system consisting of PVC tubes of an inner diameter of $6 \mathrm{~mm}$ (Deutsch \& Neumann, Berlin, Germany) fixed with cable connection to the plastic bag (OBO Bettermann $\mathrm{GmbH} \&$ Co. KG, Menden, Germany) were established. A ventilation system was used for measuring soil respiration within the plastic bags. Pipes from the insight of the plastic bag were connected to $1 \mathrm{M}$ sodium-hydroxide solution and opened once a day to allow free air exchange.

Seedlings were acclimatized for two days at $400 \mathrm{ppm}$ with unlabeled $\mathrm{CO}_{2}$ before the ${ }^{13} \mathrm{C}$ labeling started by using a $0.5 \mathrm{Mol}$ solution of ${ }^{12} \mathrm{C}$ sodium carbonate (KMF Laborchemie Handes, Lohmar, Germany). $\mathrm{CO}_{2}$ was liberated from sodium-carbonate by adding $5 \mathrm{Mol}$ lactic acid. After acclimation seedlings were exposed to ${ }^{13} \mathrm{CO}_{2}$ for 3 days for $16 \mathrm{~h}$ /day with a maximum $\mathrm{CO}_{2}$ concentration of 1800 ppm. For ${ }^{13} \mathrm{CO}_{2}$ labeling we used $0.5 \mathrm{Mol}$ solution with 99 atom $\%{ }^{13} \mathrm{C}$ sodium-carbonate (SigmaAldrich, Traufkirchen, Germany). To reduce dilution of the ${ }^{13} \mathrm{CO}_{2}$ by plant derived $\mathrm{CO}_{2}$ at night, $\mathrm{CO}_{2}$ in the chamber was absorbed by pumping the air through $1 \mathrm{Mol}$ sodium-hydroxide solution. $\mathrm{CO}_{2}$ concentration in the chamber was monitored using an infrared gas analyzer (CARBOCAP' ${ }^{\text {TM }}$ Serie GMM220, Driesen + Kern GmbH, Bad Bramstedt, Germany).

\subsection{Sampling}

Five seedlings of each batch were harvested after 5 days, the other five after 20 days after start of the ${ }^{13} \mathrm{C}$ labeling, resulting in 10 replicates per tree species and sampling date. Control seedlings were kept in a greenhouse at respective conditions and harvested at the same dates as the labeled seedlings. Litter was collected and soil samples were taken from 0 - 10 and $10-25 \mathrm{~cm}$ soil depth. Soil animals of litter and soil were extracted by heat (Kempson et al. 1963) and collected in glycolwater solution (1:1). Animals were stored at $-15^{\circ} \mathrm{C}$ in $70 \%$ ethanol until identification and further processing.

\subsection{Stable isotope analysis}

For dual ${ }^{13} \mathrm{C}$ and ${ }^{15} \mathrm{~N}$ measurement $100-300 \mu \mathrm{g}$ of animal tissue were transferred into tin capsules and dried at $40^{\circ} \mathrm{C}$ for $48 \mathrm{~h}$; several individuals of small species had to be pooled to obtain enough tissue material for stable isotope analysis. Large animal species were dried at $40^{\circ} \mathrm{C}$ for $48 \mathrm{~h}$, 
fragmented mechanically and a representative subsample was analyzed. Stable isotope ratios were analyzed with a coupled system consisting of an elemental analyzer (NA 1500, Carlo Erba, Milan, Italy) and a mass spectrometer (MAT 251, Finnigan, Bremen, Germany). Abundances of ${ }^{13} \mathrm{C}$ and ${ }^{15} \mathrm{~N}$ are expressed using the $\delta$ notation with $\delta_{\text {sample }}[\% o]=\left[\left(R_{\text {sample }}-R_{\text {standard }}\right) / R_{\text {standard }}\right] \times 1000 ; R_{\text {sample }}$ and $R_{\text {standard }}$ represent the ${ }^{13} \mathrm{C} /{ }^{12} \mathrm{C}$ and ${ }^{15} \mathrm{~N} /{ }^{14} \mathrm{~N}$ ratios of samples and standard, respectively. For ${ }^{13} \mathrm{C} P D$ Belemnite (PBD) and for ${ }^{15} \mathrm{~N}$ atmospheric nitrogen served as the primary standard. Acetanilide $\left(\mathrm{C}_{8} \mathrm{H}_{9} \mathrm{NO}\right.$, Merck) was used for internal calibration.

For analyzing the enrichment in ${ }^{13} \mathrm{C}$ and ${ }^{15} \mathrm{~N}$ of soil animal taxa we calculated the difference in delta values between animals from labeled and unlabeled trees as $\Delta_{\text {element }}=\delta_{\text {label }}-\delta_{\text {control, }}$ with $\Delta_{\text {element }}$ the $\Delta^{13} \mathrm{C}$ and $\Delta^{15} \mathrm{~N}$ values. Samples with mean $\Delta^{13} \mathrm{C}$ and $\Delta^{15} \mathrm{~N}$ in the range of two standard deviations of $\delta^{13} \mathrm{C}$ and $\delta^{15} \mathrm{~N}$ of respective control samples were assumed not to be enriched and set to zero.

\subsection{Statistical analysis}

$\Delta{ }^{15} \mathrm{~N}$ and $\Delta^{13} \mathrm{C}$ values of eleven soil animal taxa were analyzed separately using linear mixed effects models (Pinheiro et al. 2013) including a random effect of tree identity (tree ID) to allow testing for the effect of Tree species and Sampling date and their possible interactions on $\mathrm{C}$ and $\mathrm{N}$ incorporation into soil animal taxa avoiding pseudo-replication of soil animal taxa of the same tree. $\Delta{ }^{15} \mathrm{~N}$ and $\Delta^{13} \mathrm{C}$ values were log-transformed to improve homogeneity of variance. The model was simplified by stepwise reduction ending up with two models, one for enrichment in $\mathrm{C}$ and one for enrichment in $\mathrm{N}$. To inspect differences between species for $\mathrm{C}$ and $\mathrm{N}$ enrichment contrast analyses were performed testing differences within each level of Tree species. A linear mixed effects model with the intercept set to zero was used to inspect $\mathrm{C}$ and $\mathrm{N}$ enrichment in animal taxa to be significantly different from zero within each level of Tree species.

\section{Results}

\subsection{Natural abundance}

Natural abundance $\delta^{13} \mathrm{C}$ signatures of soil animal taxa spanned $5.06 \%$ from $-25.33 \pm 0.4 \%$ in Nothrus palustris (Oribatida) to $-20.27 \pm 0.73 \%$ in Steganacarus magnus (Oribatida), while natural $\delta^{15} \mathrm{~N}$ signatures spanned $7.44 \%$ o from $-3.00 \pm 0.77 \%$ o in N.palustris to $4.44 \pm 1.34 \%$ in Onychiuridae (Collembola) (Supplementary material Appendix A1).

\subsection{Carbon}

Each of the 11 analyzed soil animal taxa was enriched in ${ }^{13} \mathrm{C}$ (Supplementary material Appendix A2) with $\Delta^{13} C$ values ranging between 0.75 and $4199 \%$, and differing significantly between species $\left(F_{10,67}=87.28, p=<0.001\right)$. Incorporation of root-derived $C$ declined in the order Onychiuridae $(1748 \pm 1456 \%)>$ Tomocerus vulgaris $(722.1 \pm 1300 \%$ o) $>$ juvenile Polydesmidae $(451.5 \pm 398.0$ 
$\%$ ) > Hypochthonius rufulus $(377.2 \pm 202.1 \%$ ) $>$ Veigaia nemorensis $(319.2 \pm 386.3 \%$ o) > Tomocerus flavescens $(120.6 \pm 89.56 \%$ o $)>$ S. magnus $(43.45 \pm 48.50 \%$ o) > Uroseius cylindricus $(13.53 \pm 8.65$ $\%$ ) > Trachytes aegrota $(9.48 \pm 5.14 \%$ o $)>$ Uropoda cassidea $(8.23 \pm 3.81 \%$ o $)>N$. palustris $(6.96 \pm$ $5.06 \%$ ). The incorporation differed between tree species (significant Animal taxa $\times$ Tree species interaction; $F_{10,67}=4.68, p=<0.001$, Supplementary material Appendix A3), but soil animal taxa generally were more enriched in the beech as compared to the ash rhizosphere (Fig. 4.1). Animal taxa differentially incorporated root-derived $\mathrm{C}$ at the two sampling dates (significant Animal taxa $\times$ Sampling date interaction; $F_{10,67}=3.91, p=<0.001$ ), which was mainly due to significant higher enrichment on day 20 after labeling in $U$. cassidea $(10.58 \pm 1.28 \%$ o) as compared to after 5 days after labeling $(5.88 \pm 1.22 \%$ ).

\subsection{Nitrogen}

Six of the 11 analyzed soil animal taxa were significantly enriched in ${ }^{15} \mathrm{~N}$ (Supplementary material Appendix A2) with $\Delta^{15} \mathrm{~N}$ values ranging between zero and $121.0 \%$, and differing significantly between species $\left(F_{10,77}=7.55, p=<0.001\right)$. Incorporation of root-derived $N$ declined in the order Onychiuridae $(27.93 \pm 38.92 \%$ o $)>$ juv. Polydesmidae $(7.15 \pm 16.04 \%$ o $)>V$. nemorensis $(6.83 \pm 15.39$ $\%$ ) $>$ H. rufulus $(5.42 \pm 4.26 \%$ o $)>T$. vulgaris $(4.83 \pm 12.03 \%$ o $)>T$. flavescens $(1.27 \pm 1.72 \%$ o $)>U$. cylindricus $(0.6 \pm 0.62 \%)>N$. palustris $(0.47 \pm 0.77 \%$ o $)>$ S. magnus $(0.42 \pm 0.83 \%$ o $)>U$. cassidea $(0.35 \pm 0.47 \%$ o $)>T$. aegrota $(0.22 \pm 0.33 \%$ o). However, the incorporation differed between tree species (significant Animal taxa $\times$ Tree species interaction; $F_{10,77}=2.90, p=<0.004$, Supplementary material Appendix A3), which was mainly due to significant higher incorporation in Onychiuridae in the beech as compared to the ash rhizosphere $\left(F_{1,11}=5.37, p=0.046\right.$; Fig. 4.1). Incorporation of root-derived $N$ did not vary with sampling date $\left(F_{1,29}=0.003, p=0.952\right)$ and therefore sampling date was removed from the final model.

\section{Discussion}

\subsection{Natural abundance}

The classification into trophic groups according to natural variations in $\delta^{15} \mathrm{~N}$ signatures of the studied soil animal taxa resembles earlier findings (Scheu \& Falca 2000; Schneider et al. 2004; Chahartaghi et al. 2005; Maraun et al. 2011; Klarner et al. 2013). High $\delta^{15} \mathrm{~N}$ signatures in Onychiuridae (Collembola) has been reported previously (Chahartaghi et al. 2005; Semenina \& Tiunov 2011), however, rather than living on animal prey high ${ }^{15} \mathrm{~N}$ signatures may also indicate feeding on mycorrhiza (Pollierer et al. 2009) as mycorrhiza sheaths of root tips are enriched in ${ }^{15} \mathrm{~N}$ (Högberg et al. 1996). 


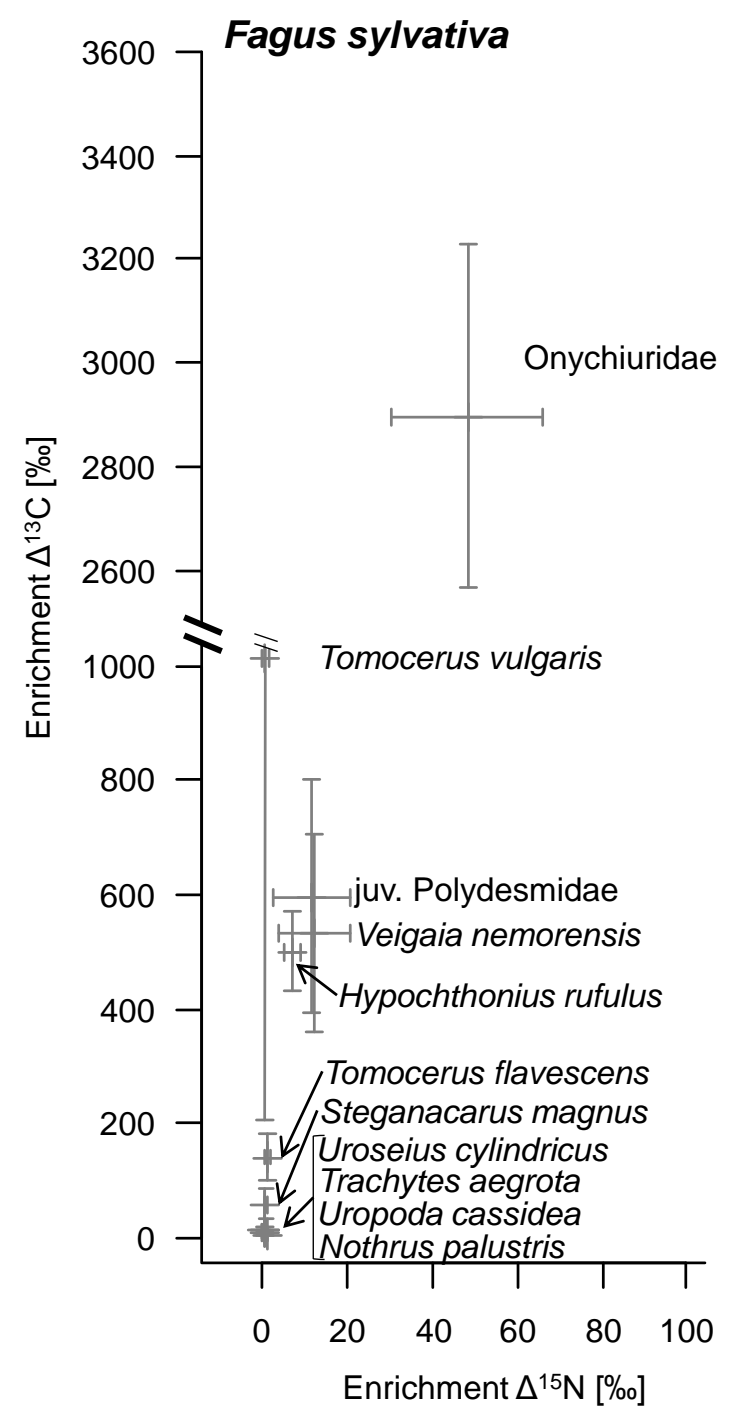

Fraxinus excelsior

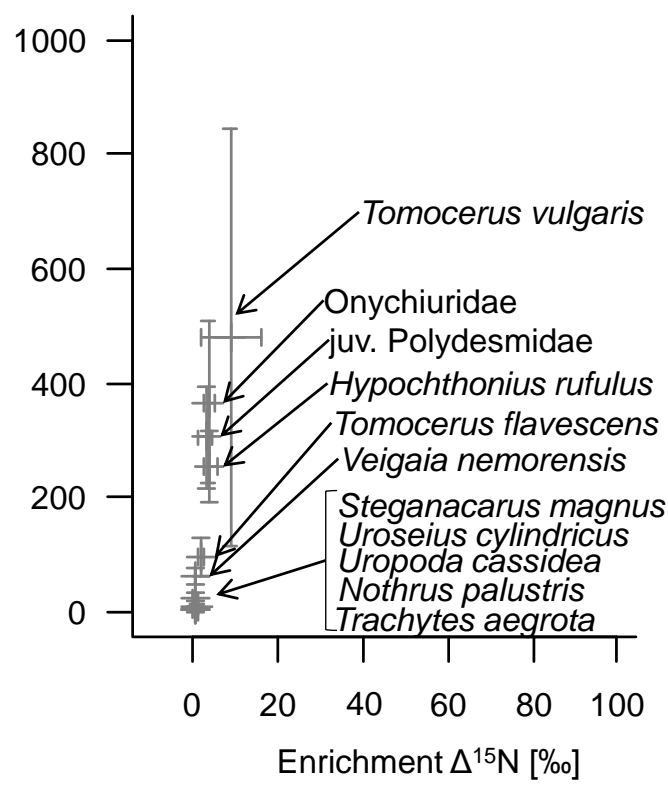

Fig. 4.1: Enrichment in $15 \mathrm{~N}$ and $13 \mathrm{C}$ in soil animal species / taxa in the rhizosphere of beech and ash. Means and standard error (SE).

\subsection{Incorporation of root-derived C}

Each of the analyzed soil animal taxa incorporated root-derived $\mathrm{C}$ short after labeling indicating that recently plant assimilated $C$ is rapidly transferred into the soil animal food web of beech and ash trees. This reinforces the importance of root-derived $\mathrm{C}$ in fueling soil animal food webs (Pollierer et al. 2007; Eissfeller et al. 2013). However, incorporation of root-derived C varied markedly between soil animal taxa as shown previously (Eissfeller et al. 2013). Onychiuridae were most enriched in ${ }^{13} \mathrm{C}$ and ${ }^{15} \mathrm{~N}$ with the ${ }^{13} \mathrm{C}$ enrichment exceeding that in fine roots indicating that they fed on root and / or mycorrhizal tissue more enriched in ${ }^{13} \mathrm{C}$ than bulk root tissue. Indeed, mycorrhiza were more enriched in ${ }^{13} \mathrm{C}$ as compared to roots (S. Ammerschubert, unpubl. data) reflecting that recently assimilated C is rapidly transferred to mycorrhiza (Johnson et al. 2002). Supporting the conclusion that Onychiuridae fed on root and / or mycorrhizal tissue, it has been shown previously 
that Onychiuridae feed on roots, however, this has only been shown for herbaceous plants (Endlweber et al. 2009). Further, in food choice experiments it has been shown that Collembola feed on mycorrhizal fungi (Shaw 1988). In line with these findings Collembola have been shown to rapidly incorporate root-derived C in field experiments (Albers et al. 2006; Larsen et al. 2007; Ostle et al. 2007). Also, the fast tissue turnover of Collembola likely contributed to the high incorporation of root-derived $C$ in Onychiuridae, as previously suggested (Ostle et al. 2007).

In contrast to Onychiuridae, ${ }^{13} \mathrm{C}$ enrichment in juvenile Polydesmidae did not exceed that in fine roots, but they were also highly enriched in ${ }^{13} \mathrm{C}$ and ${ }^{15} \mathrm{~N}$ indicating that they also feed on root material. Indeed, it has been shown previously that Polydesmidae feed on root hairs (Gunn \& Cherrett 1993) and there is evidence that mixed diets of fungi and plant material increase fertility and growth of Polydesmidae (David \& Célérier 1997). However, in a root labeling experiment Diplopoda were only moderately enriched in ${ }^{13} \mathrm{C}$ suggesting that they predominantly feed on other resources (Gilbert et al. 2014). As Diplopoda including Polydesmidae are strongly sclerotized slow tissue turnover may have contributed to low incorporation of root-derived C.

The two predacious mite species studied, H. rufulus (Oribatida) and V. nemorensis (Gamasina), also were highly enriched in ${ }^{13} \mathrm{C}$ indicating that they heavily rely on root resources presumably via feeding on Nematoda or Collembola relying on root-derived C. Indeed, V. nemorensis (Koehler 1999; Walter \& Proctor 2013) and H. rufulus (Riha 1951; Behan-Pelletier \& Hill 1983) are known to feed on Collembola including Onychiuridae (Hurlbutt 1968). Further, there is increasing evidence that Gamasina heavily rely on Nematoda prey (Heidemann et al. 2014b), but see also (Kudrin et al. 2015).

In the two analyzed Tomocerus species the enrichment in ${ }^{13} \mathrm{C}$ was intermediate, indicating that to some extent root-derived resources contribute to their diet. As incorporation of root-derived $\mathrm{N}$ was low, incorporation of root-derived resources unlikely was due to root feeding. Tomocerus species are known to feed on a variety of food materials including litter but also fungi and bacteria in the rhizosphere (Pollierer et al. 2012), algae (Wolters 1985) as well as Nematoda (Heidemann et al. 2014a). Omnivory in Collembola has been proposed previously (Filser 2002) and mixed diets have been shown to increase growth in Collembola (Scheu \& Simmerling 2004). The high variance in the natural abundance of stable isotopes found in the present study also indicate that the diet of Tomocerus species varies between individuals. Overall, incorporation of root-derived C but little root-derived $\mathrm{N}$ likely was due to feeding on mycorrhizal fungi but the intermediate ${ }^{13} \mathrm{C}$ signature suggests that they only form a small fraction of the diet of Tomocerus species.

The Uropodina species studied, U. cassidea, U. cylindricus and $T$ aegrota, incorporated little root-derived C. Uropodina are slow moving mites which are assumed to feed on Nematoda (Muraoca \& Ishibashi 1976; Buryn \& Brandl 1992; Heidemann et al. 2014a). However, at least $T$. 
aegrota also has been suggested to feed on fungi (Scheu \& Falca 2000; Constantinescu \& Cristescu 2007). The low contribution of root-derived $C$ indicate that their prey little relies on root-derived resources. However, in the long-term $U$. cassidea has been shown to rely on root-derived $C$ (Pollierer et al. 2007). Presumably, slow tissue turnover contributed to the low incorporation of root-derived $C$ in the present study.

Similar to Uropodina, the Oribatida species N. palustris and S. magnus were little enriched in ${ }^{13} \mathrm{C}$ indicating that they little rely on root-derived resources. This is consistent with their trophic position as primary decomposers suggesting that they predominantly feed on dead organic matter such as leaf litter (Rihani et al. 1995; Schneider et al. 2004). Higher incorporation of root-derived C in S. magnus than in N. palustris suggests differential incorporation of resources supporting earlier findings on niche differentiation in Oribatida (Scheu \& Falca 2000; Schneider et al. 2004).

\subsection{Incorporation of root-derived N}

Six of eleven analyzed soil animal taxa incorporated root-derived $\mathrm{N}$ indicating that $\mathrm{N}$ in plant leaves also is rapidly transferred to the roots and into the soil animal food web. Although this pathway of $\mathrm{N}$ received little attention until today (but see e.g., Brumme et al. (1992), it has been shown recently that root-derived $\mathrm{N}$ contributes to the nutrition of soil animals in the field (S. Zieger, unpubl. data). Notably, incorporation of root-derived $\mathrm{N}$ varied significantly between soil animal taxa and, in contrast to $\mathrm{C}$, some species did not incorporate any. Presumably, this is due to the fact that rhizodeposits predominantly consist of $\mathrm{C}$ rather than $\mathrm{N}$ compounds (Merbach et al. 1999). However, two secondary decomposers, i.e. juvenile Polydesmidae (Diplopoda) and Onychiuridae (Collembola) incorporated root-derived $\mathrm{N}$ presumably via feeding on roots and / or root hairs, supporting our conclusion that they heavily rely root-derived resources.

\subsection{Variations with time}

In line with Ostle et al. (2007) incorporation of root-derived C into soil animal taxa varied with time, but time had no overall effect on $\mathrm{C}$ incorporation indicating that the assimilated $\mathrm{C}$ was rapidly transported into roots, entered the soil animal food web and stayed there for at least 20 days, which contrasts our third hypothesis. Potentially, however, incorporation of root-derived $\mathrm{C}$ peaked before our first sampling date at day 5 after labeling. Rather being generally different between the sampling dates, soil animal species differentially incorporated $\mathrm{C}$ with time with $U$. cassidea incorporating more $\mathrm{C}$ after 20 days than after 5 days, indicating that the prey of this predatory mite only slowly incorporated root-derived $\mathrm{C}$. In contrast to $\mathrm{C}$, incorporation of root-derived $\mathrm{N}$ did not vary with time suggesting that $\mathrm{N}$ leakage and incorporation into the soil food web stayed rather constant even after the addition tracer was terminated. 


\subsection{Variations with tree species}

The incorporation of root-derived $\mathrm{C}$ into the soil animal food web significantly differed between tree species with the incorporation in the beech rhizosphere exceeding that in the ash rhizosphere. This contrasts results of a long-term experiment in which no difference in the flux of root-derived C from beech and ash into soil animals was found after five months (Eissfeller et al. 2013). This indicates that in the long-term the low flux of root-derived resources from ash into the soil animal food web is compensated by the provisioning of other root-derived resources, potentially dead roots. The differential incorporation of $\mathrm{C}$ with tree species in the present experiment indicates that the resources provided by roots for fueling rhizosphere food webs vary with time. Presumably, differences between tree species in the provisioning of root-derived resources are related to the different types of mycorrhiza in beech and ash with the former being associated with EMF and the latter with AMF (Phillips \& Fahey 2006; Brzostek et al. 2012). Selective feeding on EMF has been found for the Protura Acerentomon sp. (S. Zieger, unpubl. data), whereas the species investigated in this study likely fed on mixed diets of root-derived and other resources which is widespread in soil animals (Scheu \& Falca 2000; Raubenheimer \& Simpson 2004; Scheu \& Simmerling 2004). However, the high enrichment in ${ }^{13} \mathrm{C}$ and ${ }^{15} \mathrm{~N}$ in Onychiuridae in the beech but not in the ash rhizosphere indicates that Onychiuridae feed on EMF or roots associated with EMF. In fact EMF typically forms a dense mantle around roots and likely is ingested by species feeding on roots. The predatory mites $H$. rufulus, $T$. aegrota, $V$. nemorensis also incorporated more ${ }^{13} \mathrm{C}$ in the beech as compared to the ash rhizosphere suggesting that they selectively feed on EMF associated prey species, potentially Onychiuridae and root associated Nematoda. 


\subsection{Conclusions}

All soil animal species studied incorporated root-derived $\mathrm{C}$ supporting earlier findings that rootderived $\mathrm{C}$ plays an important role in fueling soil animal food webs. Notably, not only root-derived $\mathrm{C}$, but also root-derived $\mathrm{N}$ was incorporated into the soil animal food web indicating that plant $\mathrm{N}$ contributes to the nutrition of soil animals thereby alleviating $\mathrm{N}$ deficiency in soil animal food webs. However, in contrast to $\mathrm{C}$ not all animal species incorporated root-derived $\mathrm{N}$, presumably as rhizodeposits predominantly consist of $\mathrm{C}$ rather than $\mathrm{N}$ compounds. Differential incorporation of root $\mathrm{C}$ and $\mathrm{N}$ suggests that root resources contribute to niche differentiation in soil animal species. Incorporation of root $\mathrm{C}$, but not root $\mathrm{N}$, varied with time suggesting that root-derived C not only contributes to animal metabolism, but to animal body tissue formation and quickly is propagated from low to high trophic levels. Notably, incorporation of root-derived $\mathrm{C}$ and $\mathrm{N}$ into soil animals varied with tree species, i.e. between beech and ash indicating that tree identity and mycorrhizal type plays an important role in fueling soil animal food webs. Overall, the results underline the importance of root-derived resources in fueling soil animal food webs and suggest that this not only applies to $\mathrm{C}$, but also for $\mathrm{N}$. 


\section{Acknowledgments}

This project was funded by the German Research Foundation (GRK1086/2, project A04). We are grateful to Prof. Ammer for study site advice. We thank Tobias Lauermann, Silke Ammerschubert and Janine Sommer for help excavating trees from the forest. Bernd Kopka, Thomas Klein from the Labor für Radioisotope (LARI, University of Göttingen) for technical advice and help in using the plant growth chamber and the Kompetenzzentrum Stabile Isotope (KOSI, University of Göttingen) for measuring stable isotopes.

\section{References}

Albers, D., Schaefer, M. \& Scheu, S. (2006) Incorporation of plant carbon into the soil animal food web of an arable system. Ecology, 87, 235-245.

Anderson, J.M. (1975) The enigma of soil animal diversity. Progress in Soil Zoology Proceedings of the Fifth International Colloquium of Soil Zoology (ed J. Vaněk), pp. 51-58. Academia, Prague.

Bais, H.P., Weir, T.L., Perry, L.G., Gilroy, S. \& Vivanco, J.M. (2006) The role of root exudates in rhizosphere interactions with plants and other organisms. Annual Review of Plant Biology, 57, 233-266.

Behan-Pelletier, V. \& Hill, S. (1983) Feeding habitat of sixteen species of Oribatei (Acari) from an acid peat bog, Glenamoy Ireland. Revue d'Écologie et de Biologie du Sol, 20, 221 - 267.

Brose, U. \& Scheu, S. (2014) Into darkness: unravelling the structure of soil food webs. Oikos, 123, 1153-1156.

Brumme, R., Leimcke, U. \& Matzner, E. (1992) Interception and uptake of NH4 and NO3 from wet deposition by above-ground parts of young beech (Fagus silvatica L.) trees. Plant and soil, 142, 273-279.

Brzostek, E.R., Greco, A., Drake, J.E. \& Finzi, A.C. (2012) Root carbon inputs to the rhizosphere stimulate extracellular enzyme activity and increase nitrogen availability in temperate forest soils. Biogeochemistry, 115, 65-76.

Buryn, R. \& Brandl, R. (1992) Are the morphometrics of chelicerae correlated with diet in mesostigmatid mites (Acari)? Experimental and Applied Acarology, 14, 67-82.

Cesarz, S., Fender, A.-C., Beyer, F., Valtanen, K., Pfeiffer, B., Gansert, D., Hertel, D., Polle, A., Daniel, R., Leuschner, C. \& Scheu, S. (2013) Roots from beech (Fagus sylvatica L.) and ash (Fraxinus excelsior L.) differentially affect soil microorganisms and carbon dynamics. Soil Biology \& Biochemistry, 61, 23-32.

Chahartaghi, M., Langel, R., Scheu, S. \& Ruess, L.R. (2005) Feeding guilds in Collembola based on nitrogen stable isotope ratios. Soil Biology \& Biochemistry, 37, 1718-1725.

Constantinescu, I.C. \& Cristescu, C. (2007) Studies on the trophic preferences of certain Uropodina mites (Acarina: Anactinotrichida, Uropodina) for some taxa of imperfect fungi. Analele Ştiinţifice ale Universităţii „Al. I. Cuza” Iaşi, s. Biologie animală, 83-87.

David, J.-F. \& Célérier, M.-L. (1997) Effects of yeast on the growth and reproduction of the saprophagous millipede Polydesmus angustus (Diplopoda, Polydesmidae). Biology and Fertility of Soils, 24, 66-69.

Digel, C., Curtsdotter, A., Riede, J., Klarner, B. \& Brose, U. (2014) Unravelling the complex structure of forest soil food webs: Higher omnivory and more trophic levels. Oikos, 123, 1157-1172. 
Ehnes, R.B., Pollierer, M.M., Erdmann, G., Klarner, B., Eitzinger, B., Digel, C., Ott, D., Maraun, M., Scheu, S. \& Brose, U. (2014) Lack of energetic equivalence in forest soil invertebrates. Ecology, 95, 527-537.

Eissfeller, V., Beyer, F., Valtanen, K., Hertel, D., Maraun, M., Polle, A. \& Scheu, S. (2013) Incorporation of plant carbon and microbial nitrogen into the rhizosphere food web of beech and ash. Soil Biology \& Biochemistry, 62, 76-81.

Endlweber, K., Ruess, L.R. \& Scheu, S. (2009) Collembola switch diet in presence of plant roots thereby functioning as herbivores. Soil Biology \& Biochemistry, 41, 1151-1154.

Filser, J. (2002) The role of Collembola in carbon and nitrogen cycling in soil. Pedobiologia, 46, 234245.

Gannes, L.Z., O’Brien, D.M. \& del Rio, C.M. (1997) Stable isotopes in animal ecology: Assumptions, caveats, and a call for more laboratory experiments. Ecology, 78, 1271-1276.

Gilbert, K.J., Fahey, T.J., Maerz, J.C., Sherman, R.E., Bohlen, P., Dombroskie, J.J., Groffman, P.M. \& Yavitt, J.B. (2014) Exploring carbon flow through the root channel in a temperate forest soil food web. Soil Biology \& Biochemistry, 76, 45-52.

Glanville, H., Rousk, J., Golyshin, P. \& Jones, D.L. (2012) Mineralization of low molecular weight carbon substrates in soil solution under laboratory and field conditions. Soil Biology and Biochemistry, 48, 88-95.

Gunn, A. \& Cherrett, J.M. (1993) The Exploitation of Food Resources by Soil Meso-Invertebrates and Macro-Invertebrates. Pedobiologia, 37, 303-320.

van Hees, P.A.W., Jones, D.L., Finlay, R., Godbold, D.L. \& Lundström, U.S. (2005) The carbon we do not see - the impact of low molecular weight compounds on carbon dynamics and respiration in forest soils: a review. Soil Biology and Biochemistry, 37, 1-13.

Heidemann, K., Hennies, A., Schakowske, J., Blumenberg, L., Ruess, L.R., Scheu, S. \& Maraun, M. (2014a) Free-living nematodes as prey for higher trophic levels of forest soil food webs. Oikos, 123, 1199-1211.

Heidemann, K., Ruess, L.R., Scheu, S. \& Maraun, M. (2014b) Nematode consumption by mite communities varies in different forest microhabitats as indicated by molecular gut content analysis. Experimental \& Applied Acarology, 64, 49-60.

Högberg, P., Högberg, M.N., Göttlicher, S.G., Betson, N.R., Keel, S.G., Metcalfe, D.B., Campbell, C.D., Schindlbacher, A., Hurry, V., Lundmark, T., Linder, S. \& Näsholm, T. (2008) High temporal resolution tracing of photosynthate carbon from the tree canopy to forest soil microorganisms. New Phytologist, 177, 220-228.

Högberg, P., Högbom, L., Schinkel, H., Högberg, M., Johannisson, C. \& Wallmark, H. (1996) 15N abundance of surface soils, roots and mycorrhizas in profiles of European forest soils. Oecologia, 108, 207-214.

Hurlbutt, H.W. (1968) Coexistence and Anatomical Similarity in Two Genera of Mites, Veigaia and Asca. Systematic Biology, 17, 261-271.

Hyodo, F. (2015) Use of stable carbon and nitrogen isotopes in insect trophic ecology. Entomological Science, 18, 295-312.

Johnson, D., Leake, J.R., Ostle, N., Ineson, P. \& Read, D.J. (2002) In situ $13 \mathrm{CO} 2$ pulse-labelling of upland grassland demonstrates a rapid pathway of carbon flux from arbuscular mycorrhizal mycelia to the soil. New Phytologist, 153, 327-334. 
Kempson, D., Lloyd, M. \& Ghelardi, R. (1963) A new extractor for woodland litter. Pedobiologia, 3, $1-21$.

Klarner, B., Maraun, M. \& Scheu, S. (2013) Trophic diversity and niche partitioning in a species rich predator guild - Natural variations in stable isotope ratios $(13 \mathrm{C} / 12 \mathrm{C}, 15 \mathrm{~N} / 14 \mathrm{~N})$ of mesostigmatid mites (Acari, Mesostigmata) from Central European beech forests. Soil Biology \& Biochemistry, 57, 327-333.

Koehler, H.H. (1999) Predatory mites (Gamasina, Mesostigmata). Agriculture, Ecosystems \& Environment, 74, 395-410.

Kudrin, A.A., Tsurikov, S.M. \& Tiunov, A. V. (2015) Trophic position of microbivorous and predatory soil nematodes in a boreal forest as indicated by stable isotope analysis. Soil Biology and Biochemistry, 86, 193-200.

Kuzyakov, Y. \& Gavrichkova, O. (2010) Time lag between photosynthesis and carbon dioxide efflux from soil: a review of mechanisms and controls. Global Change Biology, 16, 3386-3406.

Larsen, T., Gorissen, A., Krogh, P.H., Ventura, M. \& Magid, J. (2007) Assimilation dynamics of soil carbon and nitrogen by wheat roots and Collembola. Plant and Soil, 295, 253-264.

Leake, J.R., Donnelly, D.P. \& Boddy, L. (2002) Interactions Between Ecto-mycorrhizal and Saprotrophic Fungi. Mycorrhizal Ecology Ecological Studies 157. (eds M.G.A. van der Heijden \& I.R. Sanders), pp. 345-372. Springer Berlin Heidelberg, Berlin, Heidelberg.

Lemanski, K. \& Scheu, S. (2014a) Incorporation of 13C labelled glucose into soil microorganisms of grassland: Effects of fertilizer addition and plant functional group composition. Soil Biology and Biochemistry, 69, 38-45.

Lemanski, K. \& Scheu, S. (2014b) Fertilizer addition lessens the flux of microbial carbon to higher trophic levels in soil food webs of grassland. Oecologia, 176, 487-496.

Maraun, M., Erdmann, G., Fischer, B.M., Pollierer, M.M., Norton, R.A., Schneider, K. \& Scheu, S. (2011) Stable isotopes revisited: Their use and limits for oribatid mite trophic ecology. Soil Biology \& Biochemistry, 43, 877-882.

Merbach, W., Mirus, E., Knof, G., Remus, R., Ruppel, S., Russow, R., Gransee, A. \& Schulze, J. (1999) Release of carbon and nitrogen compounds by plant roots and their possible ecological importance. Journal of Plant Nutrition and Soil Science, 162, 373-383.

Muraoca, M. \& Ishibashi, N. (1976) Nematode-Feeding Mites and Their Feeding Behavior. Applied Entomology and Zoology, 11, 1-7.

Ostle, N.J., Briones, M.J.I., Ineson, P., Cole, L., Staddon, P. \& Sleep, D. (2007) Isotopic detection of recent photosynthate carbon flow into grassland rhizosphere fauna. Soil Biology \& Biochemistry, 39, 768-777.

Phillips, R.P. \& Fahey, T.J. (2005) Patterns of rhizosphere carbon flux in sugar maple (Acer saccharum) and yellow birch (Betula allegheniensis) saplings. Global Change Biology, 11, 983995.

Phillips, R.P. \& Fahey, T.J. (2006) Tree species and mycorrhizal associations influence the magnitude of rhizosphere effects. Ecology, 87, 1302-1313.

Pinheiro, J., Bates, D., DebRoy, S. \& Sarkar, D. (2013) nlme: Linear and Nonlinear Mixed Effects Models. R package ver. 3.1-120, R package.

Pollierer, M.M., Dyckmans, J., Scheu, S. \& Haubert, D. (2012) Carbon flux through fungi and bacteria into the forest soil animal food web as indicated by compound-specific $13 \mathrm{C}$ fatty acid analysis. Functional Ecology, 26, 978-990. 
Pollierer, M.M., Langel, R., Körner, C., Maraun, M. \& Scheu, S. (2007) The underestimated importance of belowground carbon input for forest soil animal food webs. Ecology Letters, 10, 729-736.

Pollierer, M.M., Langel, R., Scheu, S. \& Maraun, M. (2009) Compartmentalization of the soil animal food web as indicated by dual analysis of stable isotope ratios (15N/14N and 13C/12C). Soil Biology \& Biochemistry, 41, 1221-1226.

Ponsard, S. \& Arditi, R. (2000) What can stable isotopes ( $\delta 15 \mathrm{~N}$ and $\delta 13 \mathrm{C}$ ) tell about the food web of soil macro-invertebrates? Ecology, 81, 852-864.

Raubenheimer, D. \& Simpson, S.J. (2004) Organismal stoichiometry: Quantifying non-independence among food components. Ecology, 85, 1203-1216.

Riha, G. (1951) Zur Ökologie der Oribatiden in Kalksteinböden. Zoologische Jahrbuecher Abteilung fuer Systematik Oekologie und Geographie der Tiere, 80, 407-450.

Rihani, M., Cancela da Fonseca, J.P. \& Kiffer, E. (1995) Decomposition of beech leaf litter by microflora and mesofauna. II. Food preferences and action of oribatid mites on different substrates. European Journal of Soil Biology, 31, 67-79.

Ruf, A., Kuzyakov, Y. \& Lopatovskaya, O. (2006) Carbon fluxes in soil food webs of increasing complexity revealed by $14 \mathrm{C}$ labelling and $13 \mathrm{C}$ natural abundance. Soil Biology \& Biochemistry, 38, 2390-2400.

Schaefer, M. (1990) The soil fauna of a beech forest on limestone: trophic structure and energy budget. Oecologia, 82, 128-136.

Scheu, S. \& Falca, M. (2000) The soil food web of two beech forests (Fagus sy/vatica) of contrasting humus type: stable isotope analysis of a macro- and a mesofauna-dominated community. Oecologia, 123, 285-296.

Scheu, S. \& Simmerling, F. (2004) Growth and reproduction of fungal feeding Collembola as affected by fungal species, melanin and mixed diets. Oecologia, 139, 347-353.

Schneider, K., Migge, S., Norton, R.A., Scheu, S., Langel, R., Reineking, A. \& Maraun, M. (2004) Trophic niche differentiation in soil microarthropods (Oribatida, Acari): evidence from stable isotope ratios (15N/14N). Soil Biology \& Biochemistry, 36, 1769-1774.

Semenina, E.E. \& Tiunov, A. V. (2011) Trophic fractionation ( $\triangle 15 N)$ in Collembola depends on nutritional status: A laboratory experiment and mini-review. Pedobiologia, 54, 101-109.

Shaw, P.J.A. (1988) A consistent hierarchy in the fungal feeding preferences of the Collembola Onychiurus armatus. Pedobiologia, 31, 179-187.

Tedersoo, L., Bahram, M., Cajthaml, T., Põlme, S., Hiiesalu, I., Anslan, S., Harend, H., Buegger, F., Pritsch, K., Koricheva, J. \& Abarenkov, K. (2015) Tree diversity and species identity effects on soil fungi, protists and animals are context dependent. The ISME journal.

Walter, D.E. \& Proctor, H.C. (2013) Mites: Ecology, Evolution \&amp; Behaviour. Springer Netherlands, Dordrecht.

Wichern, F., Eberhardt, E., Mayer, J., Joergensen, R.G. \& Müller, T. (2008) Nitrogen rhizodeposition in agricultural crops: Methods, estimates and future prospects. Soil Biology \& Biochemistry, 40, 30-48.

Wolters, V. (1985) Resource allocation in Tomocerus flavescens (Insecta, Collembola): a study with C-14-labelled food. Oecologia, 65, 229-235. 


\section{Appendix}

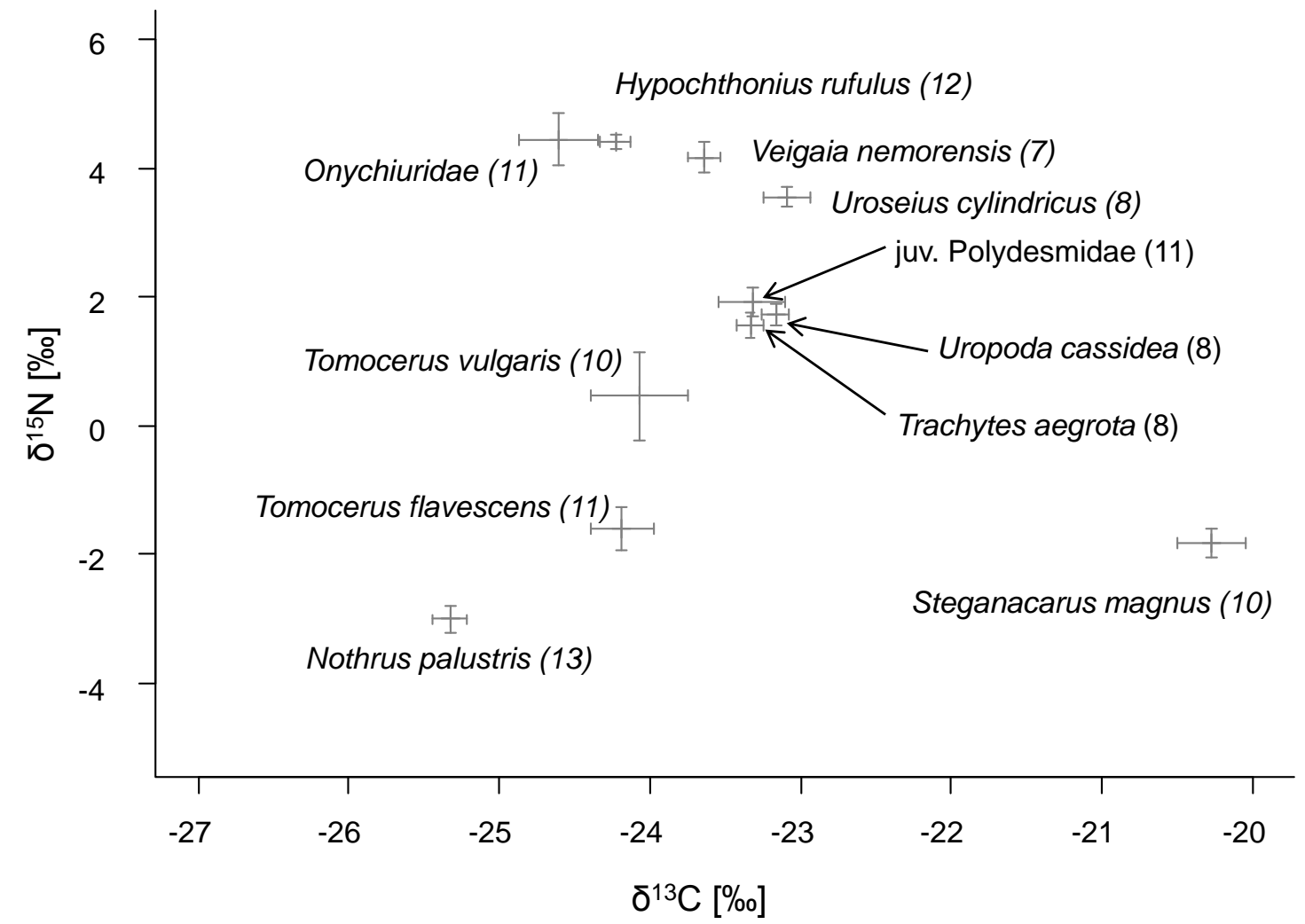

A 1: Natural abundance of $\delta 15 \mathrm{~N}$ and $\delta 13 \mathrm{C}$ signatures of the soil animal species / taxa investigated. Means and standard error (SE) with numbers of samples in brackets 
A 2: Estimate, $\mathrm{SE}, \mathrm{t}$-value and $\mathrm{P}$-value of linear mixed effect model with intercept set to zero on the enrichment ( $\mathrm{C}$ and $\mathrm{N}$ ) in Animal taxa within each level of Tree species (beech and ash).

Carbon Nitrogen

\begin{tabular}{|c|c|c|c|c|c|c|c|c|c|c|}
\hline \multirow{2}{*}{$\begin{array}{l}\text { Beech } \\
\text { Hypochthonius rufulus }\end{array}$} & \multicolumn{2}{|c|}{ Estimate SE } & \multirow{2}{*}{$\begin{array}{r}\text { t-value } \\
18.02\end{array}$} & \multicolumn{2}{|c|}{$p$-value } & \multicolumn{2}{|c|}{ Estimate SE } & \multirow{2}{*}{$\begin{array}{r}\text { t-value } \\
5.74\end{array}$} & \multicolumn{2}{|c|}{$p$-value } \\
\hline & 2.64 & 0.15 & & $<0.001$ & $* * *$ & 0.85 & 0.15 & & $<0.001$ & $* * *$ \\
\hline juvenile Polydesmidae & 2.70 & 0.15 & 18.42 & $<0.001$ & $* * *$ & 0.62 & 0.15 & 4.18 & $<0.001$ & $* * *$ \\
\hline Nothrus palustris & 0.90 & 0.15 & 6.13 & $<0.001$ & $* * *$ & 0.20 & 0.15 & 1.36 & 0.178 & \\
\hline Onychiuridae & 3.45 & 0.15 & 23.55 & $<0.001$ & $* * *$ & 1.39 & 0.15 & 9.39 & $<0.001$ & $* * *$ \\
\hline Steganacarus magnus & 1.52 & 0.15 & 10.37 & $<0.001$ & $* * *$ & .15 & 0.15 & 1.02 & 0.309 & \\
\hline Tomocerus flavescens & 2.05 & 0.15 & 13.96 & $<0.001$ & $* * *$ & 0.19 & 0.15 & 1.28 & 0.205 & \\
\hline Tomocerus vulgaris & .54 & 0.16 & 15.98 & $<0.001$ & $* * *$ & 0.09 & 0.16 & 0.54 & 0.588 & \\
\hline Trachytes aegrota & 1.15 & 0.15 & 7.88 & $<0.001$ & $* * *$ & 0.03 & 0.15 & 0.18 & 0.861 & \\
\hline Uropoda cassidea & 1.00 & 0.15 & 6.81 & $<0.001$ & $* * *$ & 0.06 & 0.15 & 0.38 & 0.707 & \\
\hline Uroseius cylindricus & 1.20 & 0.15 & 8.19 & $<0.001$ & $* * *$ & 0.14 & 0.15 & 0.95 & 0.347 & \\
\hline Veigaia nemorensis & 2.50 & 0.15 & 17.1 & $<0.001$ & $* * *$ & 0.70 & 0.15 & 4.73 & $<0.001$ & $* * *$ \\
\hline \multicolumn{11}{|l|}{ Ash } \\
\hline Hypochth & 2.39 & 0.15 & 16.46 & $<0.001$ & $* * *$ & 0.56 & 0.15 & 3.79 & $<0.001$ & $* * *$ \\
\hline juvenile Polydesmidae & 2.31 & 0.14 & 16.05 & $<0.001$ & $* * *$ & 0.40 & 0.15 & 67 & 0.009 & $* *$ \\
\hline Nothrus palustris & 0.81 & 0.14 & 5.62 & $<0.001$ & $* * *$ & 0.05 & 0.15 & 0.31 & 0.760 & \\
\hline Onychiuridae & 2.33 & 0.16 & 14.82 & $<0.001$ & $* * *$ & 0.52 & 0.16 & 3.20 & 0.002 & $* *$ \\
\hline Steganacarus magnus & 1.53 & 0.15 & 10.51 & $<0.001$ & $* * *$ & 0.06 & 0.15 & 0.39 & 0.700 & \\
\hline Tomocerus flavescens & 1.90 & 0.15 & 13.07 & $<0.001$ & $* * *$ & 0.31 & 0.15 & 2.12 & 0.038 & \\
\hline Tomocerus vulgaris & 2.02 & 0.14 & 13.94 & $<0.001$ & $* * *$ & 0.60 & 0.15 & 4.03 & $<0.001$ & $* * *$ \\
\hline Trachytes aegrota & 0.81 & 0.15 & 5.54 & $<0.001$ & $* * *$ & 0.12 & 0.15 & 0.82 & 0.417 & \\
\hline Uropoda cassidea & 0.98 & 0.14 & 6.77 & $<0.001$ & $* * *$ & 0.16 & 0.15 & 1.10 & 0.276 & \\
\hline Uroseius cylindricus & 0.98 & 0.15 & 6.76 & $<0.001$ & $* * *$ & 0.21 & 0.15 & 1.41 & 0.161 & \\
\hline Veigaia nemorensis & 1.73 & 0.16 & 10.74 & $<0.001$ & $* * *$ & 0.15 & 0.16 & 0.94 & 0.349 & \\
\hline
\end{tabular}


A3: Estimate, Std. Error, z-value and P-value of contrasts analysis between Animal taxa within each level of Tree species for $\mathrm{C}$ and $\mathrm{N}$ enrichment, modeled with full contrast matrix in a linear mixed effect model.

\begin{tabular}{|c|c|c|c|c|c|}
\hline Carbon beech & Estimate & Std. Error & z-value & P-value & \\
\hline Nothrus palustris - Hypochthonius rufulus & -1.79 & 0.18 & -10.22 & $<0.001$ & $* * *$ \\
\hline Onychiuridae - Hypochthonius rufulus & 0.82 & 0.17 & 4.70 & $<0.001$ & $* * *$ \\
\hline Steganacarus magnus - Hypochthonius rufulus & -1.13 & 0.17 & -6.60 & $<0.001$ & $* * *$ \\
\hline Tomocerus flavescens - Hypochthonius rufulus & -0.59 & 0.17 & -3.38 & 0.059 & . \\
\hline Trachytes aegrota - Hypochthonius rufulus & -1.51 & 0.17 & -8.76 & $<0.001$ & $* * *$ \\
\hline Uropoda cassidea - Hypochthonius rufulus & -1.69 & 0.17 & -9.69 & $<0.001$ & $* * *$ \\
\hline Uroseius cylindricus - Hypochthonius rufulus & -1.46 & 0.17 & -8.48 & $<0.001$ & $* * *$ \\
\hline Nothrus palustris - juv. Polydesmidae & -1.87 & 0.18 & -10.38 & $<0.001$ & $* * *$ \\
\hline Onychiuridae - juv. Polydesmidae & 0.75 & 0.17 & 4.28 & $<0.01$ & $* *$ \\
\hline Steganacarus magnus - juv. Polydesmidae & -1.21 & 0.18 & -6.80 & $<0.001$ & $* * *$ \\
\hline Tomocerus flavescens - juv. Polydesmidae & -0.66 & 0.17 & -3.79 & 0.015 & * \\
\hline Trachytes aegrota - juv. Polydesmidae & -1.58 & 0.17 & -9.17 & $<0.001$ & $* * *$ \\
\hline Uropoda cassidea - juv. Polydesmidae & -1.76 & 0.17 & -10.10 & $<0.001$ & $* * *$ \\
\hline Uroseius cylindricus - juv. Polydesmidae & -1.53 & 0.17 & -9.17 & $<0.001$ & $* * *$ \\
\hline Onychiuridae - Nothrus palustris & 2.61 & 0.18 & 14.89 & $<0.001$ & $* * *$ \\
\hline Steganacarus magnus - Nothrus palustris & 0.66 & 0.17 & 3.86 & 0.010 & $*$ \\
\hline Tomocerus flavescens - Nothrus palustris & 1.20 & 0.18 & 6.85 & $<0.001$ & $* * *$ \\
\hline Tomocerus vulgaris - Nothrus palustris & 1.70 & 0.19 & 9.03 & $<0.001$ & $* * *$ \\
\hline Veigaia nemorensis - Nothrus palustris & 1.66 & 0.18 & 9.43 & $<0.001$ & $* * *$ \\
\hline Steganacarus magnus - Onychiuridae & -1.95 & 0.17 & -11.39 & $<0.001$ & $* * *$ \\
\hline Tomocerus flavescens - Onychiuridae & -1.41 & 0.17 & -8.44 & $<0.001$ & $* * *$ \\
\hline Tomocerus vulgaris - Onychiuridae & -0.92 & 0.18 & -5.06 & $<0.001$ & $* * *$ \\
\hline Trachytes aegrota - Onychiuridae & -2.33 & 0.17 & -13.79 & $<0.001$ & $* * *$ \\
\hline Uropoda cassidea - Onychiuridae & -2.51 & 0.17 & -14.49 & $<0.001$ & $* * *$ \\
\hline Uroseius cylindricus - Onychiuridae & -2.28 & 0.17 & -13.05 & $<0.001$ & $* * *$ \\
\hline Veigaia nemorensis - Onychiuridae & -0.95 & 0.17 & -5.62 & $<0.001$ & $* * *$ \\
\hline Tomocerus vulgaris - Steganacarus magnus & 1.04 & 0.18 & 5.64 & $<0.001$ & $* * *$ \\
\hline Veigaia nemorensis - Steganacarus magnus & 1.00 & 0.17 & 5.81 & $<0.001$ & $* * *$ \\
\hline Trachytes aegrota - Tomocerus flavescens & -0.92 & 0.17 & -5.45 & $<0.001$ & $* * *$ \\
\hline Uropoda cassidea-Tomocerus flavescens & -1.10 & 0.17 & -6.34 & $<0.001$ & $* * *$ \\
\hline Uroseius cylindricus - Tomocerus flavescens & -0.87 & 0.17 & -4.98 & $<0.001$ & $* * *$ \\
\hline Trachytes aegrota - Tomocerus vulgaris & -1.42 & 0.18 & -7.72 & $<0.001$ & $* * *$ \\
\hline Uropoda cassidea - Tomocerus vulgaris & -1.59 & 0.19 & -8.60 & $<0.001$ & $* * *$ \\
\hline Uroseius cylindricus - Tomocerus vulgaris & -1.37 & 0.19 & -7.29 & $<0.001$ & $* * *$ \\
\hline Veigaia nemorensis - Trachytes aegrota & 1.38 & 0.17 & 8.03 & $<0.001$ & $* * *$ \\
\hline Veigaia nemorensis - Uropoda cassidea & 1.55 & 0.18 & 8.86 & $<0.001$ & $* * *$ \\
\hline Veigaia nemorensis - Uroseius cylindricus & 1.33 & 0.17 & 7.64 & $<0.001$ & $* * *$ \\
\hline
\end{tabular}


A3: continued

\begin{tabular}{|c|c|c|c|c|c|}
\hline Carbon ash & Estimate & Std. Error & z-value & P-value & \\
\hline Nothrus palustris - Hypochthonius rufulus & -1.71 & 0.18 & -9.44 & $<0.001$ & $* * *$ \\
\hline Steganacarus magnus - Hypochthonius rufulus & -0.88 & 0.18 & -4.84 & $<0.001$ & $* * *$ \\
\hline Trachytes aegrota - Hypochthonius rufulus & -1.67 & 0.18 & -9.34 & $<0.001$ & $* * *$ \\
\hline Uropoda cassidea - Hypochthonius rufulus & -1.49 & 0.18 & -8.46 & $<0.001$ & $* * *$ \\
\hline Uroseius cylindricus - Hypochthonius rufulus & -1.48 & 0.18 & -8.23 & $<0.001$ & $* * *$ \\
\hline Veigaia nemorensis - Hypochthonius rufulus & -0.68 & 0.19 & -3.50 & 0.040 & $*$ \\
\hline Nothrus palustris - juv. Polydesmidae & -1.63 & 0.18 & -9.20 & $<0.001$ & $* * *$ \\
\hline Steganacarus magnus - juv. Polydesmidae & -0.80 & 0.18 & -4.52 & $<0.001$ & $* * *$ \\
\hline Trachytes aegrota - juv. Polydesmidae & -1.59 & 0.18 & -8.79 & $<0.001$ & $* * *$ \\
\hline Uropoda cassidea - juv. Polydesmidae & -1.41 & 0.18 & -8.02 & $<0.001$ & $* * *$ \\
\hline Uroseius cylindricus - juv. Polydesmidae & -1.40 & 0.18 & -7.80 & $<0.001$ & $* * *$ \\
\hline Onychiuridae - Nothrus palustris & 1.64 & 0.19 & 8.75 & $<0.001$ & $* * *$ \\
\hline Steganacarus magnus - Nothrus palustris & 0.84 & 0.18 & 4.76 & $<0.001$ & $* * *$ \\
\hline Tomocerus flavescens - Nothrus palustris & 1.22 & 0.18 & 6.74 & $<0.001$ & $* * *$ \\
\hline Tomocerus vulgaris - Nothrus palustris & 1.33 & 0.18 & 7.28 & $<0.001$ & $* * *$ \\
\hline Veigaia nemorensis - Nothrus palustris & 1.03 & 0.19 & 5.28 & $<0.001$ & $* * *$ \\
\hline Steganacarus magnus - Onychiuridae & -0.80 & 0.18 & -4.39 & $<0.01$ & $* *$ \\
\hline Trachytes aegrota - Onychiuridae & -1.60 & 0.19 & -8.33 & $<0.001$ & $* * *$ \\
\hline Uropoda cassidea - Onychiuridae & -1.42 & 0.18 & -7.76 & $<0.001$ & $* * *$ \\
\hline Uroseius cylindricus - Onychiuridae & -1.41 & 0.19 & -7.52 & $<0.001$ & $* * *$ \\
\hline Trachytes aegrota - Steganacarus magnus & -0.79 & 0.18 & -4.30 & $<0.01$ & $* *$ \\
\hline Uropoda cassidea - Steganacarus magnus & -0.62 & 0.17 & -3.59 & 0.029 & $*$ \\
\hline Uroseius cylindricus - Steganacarus magnus & -0.60 & 0.18 & -3.34 & 0.067 & \\
\hline Trachytes aegrota - Tomocerus flavescens & -1.18 & 0.18 & -6.36 & $<0.001$ & $* * *$ \\
\hline Uropoda cassidea - Tomocerus flavescens & -1.00 & 0.18 & -5.64 & $<0.001$ & $* * *$ \\
\hline Uroseius cylindricus - Tomocerus flavescens & -0.99 & 0.18 & -5.37 & $<0.001$ & $* * *$ \\
\hline Trachytes aegrota - Tomocerus vulgaris & -1.29 & 0.18 & -7.08 & $<0.001$ & $* * *$ \\
\hline Uropoda cassidea - Tomocerus vulgaris & -1.11 & 0.18 & -6.20 & $<0.001$ & $* * *$ \\
\hline Uroseius cylindricus - Tomocerus vulgaris & -1.10 & 0.18 & -6.17 & $<0.001$ & $* * *$ \\
\hline Veigaia nemorensis - Trachytes aegrota & 0.99 & 0.19 & 5.27 & $<0.001$ & $* * *$ \\
\hline Veigaia nemorensis - Uropoda cassidea & 0.81 & 0.20 & 4.07 & $<0.01$ & $* *$ \\
\hline Veigaia nemorensis - Uroseius cylindricus & 0.80 & 0.20 & 4.06 & $<0.01$ & $* *$ \\
\hline
\end{tabular}


A3: continued

\begin{tabular}{|c|c|c|c|c|c|}
\hline Nitrogen beech & Estimate & Std. Error & $z$-value & P-value & \\
\hline Hypochthonius rufulus - Nothrus palustris & 0.65 & 0.19 & 3.40 & 0.053 & \\
\hline Hypochthonius rufulus - Steganacarus magnus & 0.70 & 0.19 & 3.67 & 0.022 & $*$ \\
\hline Hypochthonius rufulus - Tomocerus flavescens & 0.66 & 0.19 & 3.47 & 0.043 & $*$ \\
\hline Hypochthonius rufulus - Tomocerus vulgaris & 0.76 & 0.20 & 3.81 & 0.013 & $*$ \\
\hline Hypochthonius rufulus - Trachytes aegrota & 0.82 & 0.19 & 4.32 & $<0.01$ & $* *$ \\
\hline Hypochthonius rufulus - Uropoda cassidea & 0.79 & 0.19 & 4.17 & $<0.01$ & $* *$ \\
\hline Hypochthonius rufulus - Uroseius cylindricus & 0.71 & 0.19 & 3.73 & 0.017 & $*$ \\
\hline juv. Polydesmidae - Onychiuridae & -0.77 & 0.19 & -4.05 & $<0.01$ & $* *$ \\
\hline Nothrus palustris - Onychiuridae & -1.19 & 0.19 & -6.23 & $<0.001$ & $* * *$ \\
\hline Onychiuridae - Steganacarus magnus & 1.24 & 0.19 & 6.50 & $<0.001$ & $* * *$ \\
\hline Onychiuridae - Tomocerus flavescens & 1.20 & 0.19 & 6.30 & $<0.001$ & $* * *$ \\
\hline Onychiuridae - Tomocerus vulgaris & 1.30 & 0.20 & 6.51 & $<0.001$ & $* * *$ \\
\hline Onychiuridae - Trachytes aegrota & 1.36 & 0.19 & 7.16 & $<0.001$ & $* * *$ \\
\hline Onychiuridae - Uropoda cassidea & 1.33 & 0.19 & 7.00 & $<0.001$ & $* * *$ \\
\hline Onychiuridae - Uroseius cylindricus & 1.25 & 0.19 & 6.56 & $<0.001$ & $* * *$ \\
\hline Onychiuridae - Veigaia nemorensis & 0.69 & 0.19 & 3.62 & 0.025 & $*$ \\
\hline Trachytes aegrota - Veigaia nemorensis & -0.67 & 0.19 & -3.54 & 0.034 & $*$ \\
\hline Uropoda cassidea - Veigaia nemorensis & -0.64 & 0.19 & -3.38 & 0.058 & \\
\hline
\end{tabular}




\section{Chapter 5}

Experimental evidence that Protura selectively

feed on ectomycorrhizal fungi

Sarah L. Zieger, Stefan Scheu

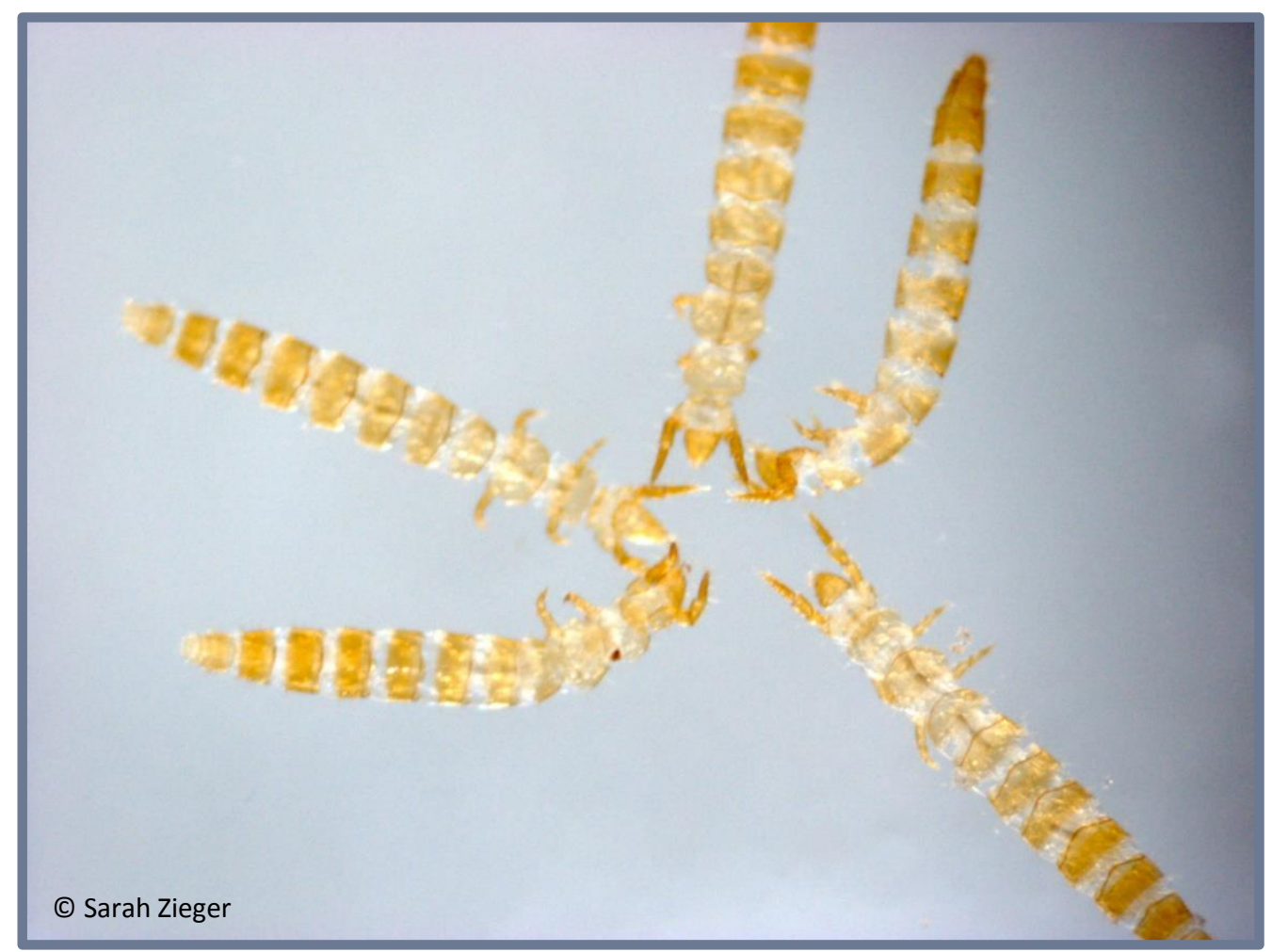




\section{Summary}

The contribution of root-derived carbon $(\mathrm{C})$ and nitrogen $(\mathrm{N})$ to the nutrition of Acerentomon $\mathrm{sp}$. (Protura) was analyzed by pulse labeling of beech (Fagus sylvatica) and ash (Fraxinus excelsior) seedlings with ${ }^{13} \mathrm{C}$ and ${ }^{15} \mathrm{~N}$. High enrichment in ${ }^{13} \mathrm{C}$, but no incorporation of ${ }^{15} \mathrm{~N}$, indicated that in the rhizosphere of beech Acerentomon sp. is exclusively feeding on ectomycorrhizal fungi (ECM) associated with beech. Differential incorporation of root-derived $\mathrm{C}$ and $\mathrm{N}$ suggests that Acerentomon sp. incorporates $\mathrm{C}$ and $\mathrm{N}$ from different resources with $\mathrm{C}$ being predominantly of plant and $\mathrm{N}$ being predominantly of soil origin. High ${ }^{13} \mathrm{C}$ enrichment short after labeling suggests that Acerentomon sp. incorporates freshly assimilated plant $\mathrm{C}$ transferred to roots and into ectomycorrhizal fungi. Compared to beech incorporation of ${ }^{13} \mathrm{C}$ in the ash rhizosphere was much lower indicating that Acerentomon sp. feeds little on arbuscular mycorrhizal fungi associated with ash. Neutral lipid fatty acid (NLFA) analysis reinforced the conclusion that Acerentomon sp. predominantly feeds on ECM by sucking up the cytoplasm of hyphal cells as 16:0 and 18:1 $\omega 9$ but not the membrane lipid 18:2 $\omega 6,9$ was incorporated into Acerentomon sp..

Keywords: Acerentomon; Carbon; Mycorrhiza; Nitrogen; Nutrition biology; Pulse labeling; Rhizosphere; Stable isotopes 
Protura are a group of tiny opaque living hexapods abundant in deciduous forests where they may reach densities of up to 91,000 ind. $\mathrm{m}^{-2}$ (Schaefer \& Schauermann 1990; Krauss \& Funke 1999). The main predators of Protura are assumed to be Gamasida (Díaz-Aguilar \& Quideau 2013), which is supported by a strong decrease in abundance with increasing numbers of Gamasida (Schneider \& Maraun 2009). Only little is known about their nutritional biology (Pass \& Szucsich 2011), but it has been assumed that they predominantly feed on mycorrhizal hyphae via sucking up hyphal cytoplasm (Sturm 1959), but experimental investigations are missing. Using pulse labeling of tree seedlings we followed the incorporation of root-derived carbon (C) and nitrogen (N) into Acerentomon sp. common in forest ecosystems. We hypothesized that Acerentomon sp. quickly incorporates recently assimilated plant $\mathrm{C}$, but not plant $\mathrm{N}$, via feeding on mycorrhiza.

In May 201240 beech (Fagus sylvatica) and 40 ash seedlings (Fraxinus excelsior) were excavated with intact surrounding soil and litter from Göttinger Wald (Reyershausen), (51 $35^{\prime} 15.39^{\prime \prime} \mathrm{N}$ $\left.9^{\circ} 58^{\prime} 57.95 " \mathrm{E}, 362 \mathrm{AMSL}\right)$. The seedlings were transferred into planting pots of $23 \times 23 \mathrm{~cm}$ and a depth of $26 \mathrm{~cm}$. Seedlings were about $1 \mathrm{~m}$ high (ranging between 73.0 and $177.5 \mathrm{~cm}$ ). In a plant growth chamber in the laboratory trees were exposed to ${ }^{13} \mathrm{CO}_{2}$ and leaves were immersed into a ${ }^{15} \mathrm{~N}$ ammonium chloride solution under controlled conditions for 3 days (S. Zieger, unpubl. data). For ${ }^{13} \mathrm{C}$ and ${ }^{15} \mathrm{~N}$ measurements an appropriate number of animals (12-20 individuals resulting in $6-$ $125 \mu \mathrm{g}$ fresh weight) was filled into tin capsules and dried at $40^{\circ} \mathrm{C}$ for $48 \mathrm{~h}$. Stable isotope ratios were analyzed using a system consisting of an elemental analyzer (NA 1500, Carlo Erba, Milan, Italy) and a mass spectrometer (MAT 251, Finnigan, Bremen, Germany) (Langel \& Dyckmans 2014). Abundances of ${ }^{13} \mathrm{C}$ and ${ }^{15} \mathrm{~N}$ in control treatments are expressed using the $\delta$ notation with $\delta_{\text {sample }}[\%$ ] $=\left[\left(R_{\text {sample }}-R_{\text {standard }}\right) / R_{\text {standard }}\right] \times 1000$, with $R_{\text {sample }}$ and $R_{\text {standard }}$ representing the ${ }^{13} \mathrm{C} /{ }^{12} \mathrm{C}$ and ${ }^{15} \mathrm{~N} /{ }^{14} \mathrm{~N}$ ratios of samples and standard, respectively. For ${ }^{13} \mathrm{C}$ PD Belemnite (PBD) and for ${ }^{15} \mathrm{~N}$ atmospheric nitrogen served as the primary standard. Acetanilide $\left(\mathrm{C}_{8} \mathrm{H}_{9} \mathrm{NO}\right.$, Merck) was used for internal calibration. Abundances of ${ }^{13} \mathrm{C}$ and ${ }^{15} \mathrm{~N}$ in the labeled treatments were expressed as atom\% ${ }^{13} \mathrm{C}=\mathrm{R}$ $/(\mathrm{R}+1)) \times 100$, with $\mathrm{R}$ the ${ }^{13} \mathrm{C} /{ }^{12} \mathrm{C}$ ratio, and atom\% $\left.{ }^{15} \mathrm{~N}=\mathrm{R} /(\mathrm{R}+1)\right) \times 100$, with $\mathrm{R}$ the ${ }^{15} \mathrm{~N} /{ }^{14} \mathrm{~N}$ ratio.

In addition to the experiment in 2012 in May 2015 (2 × 30) individuals of Acerentomon sp. were collected in the Göttinger Wald and lipids were extracted as described in Haubert et al. (2004). Neutral lipid fatty acids (NLFA) were dried in a rotation vacuum concentrator, saponified, methylated and washed following the procedures given for the Sherlock Microbial Identification System (MIDI Inc., Newark, NJ, USA; see (Ruess et al. 2002). Then, the lipid fraction was transferred into test tubes and stored at $-20^{\circ} \mathrm{C}$ until analysis via gas chromatography. The gas chromatograph (CLARUS 500, Perkin Elmer, Waltham, USA) was equipped with a flame ionization detector and a PE-5 capillary column (30 m x $0.32 \mathrm{~mm}$ i.d., $0.25 \mu \mathrm{m}$ film thickness; Perkin Elmer, Waltham, USA). Fatty acid methyl esters (FAMEs) were identified by comparing retention times of samples with 
standard mixtures containing unbranched FAMEs (C4- C24 chains) and bacterial FAMEs (for details see (Ferlian \& Scheu 2013).

Statistical analyses were performed using R v.3.1.3 (R Core Team 2015). C and N concentrations, ${ }^{13} \mathrm{C}$ and ${ }^{15} \mathrm{~N}$ atom\% of Acerentomon sp. were analyzed separately using single-factor analysis of variance (ANOVA) to test for the effect of tree species on ${ }^{13} \mathrm{C}$ and ${ }^{15} \mathrm{~N}$ values. To increase homogeneity of variances atom $\%{ }^{15} \mathrm{~N}$ and atom $\%{ }^{13} \mathrm{C}$ values were log-transformed.

Natural abundance signatures of Acerentomon sp. in control treatments of beech were depleted in ${ }^{13} \mathrm{C}\left(-26.92 \pm 0.26 \%\right.$ o) and enriched in ${ }^{15} \mathrm{~N}(3.59 \pm 1.12 \%$ o) with $45.44 \pm 2.03$ and $10.62 \pm 0.87 \mathrm{C}$ and $\mathrm{N}$ content, respectively. Unfortunately, due to low density we were unable to measure natural abundance ${ }^{15} \mathrm{~N}$ signatures of Acerentomon sp. in the ash rhizosphere. In labeled treatments $C$ signatures of Acerentomon sp. in the beech rhizosphere (5.83 \pm 2.61 atom\%) significantly exceeded that in the ash rhizosphere (1.10 \pm 0.01 atom\%), whereas $N$ enrichment was low and did not differ between tree species $(0.368 \pm 0.001$ and $0.367 \pm 0.001$ atom\% for the beech and ash rhizosphere, respectively). The most abundant NLFA was $18: 1 \omega 9$ with $49.7 \pm 5.0 \%$ of total NLFAs followed by 16:0 (25.8 \pm 5.7$)$ and $16: 1 \omega 7(20.6 \pm 0.8)$ while $18: 2 \omega 6,9$ only made up $2.9 \pm 0.6 \%$ (Fig. 5.1).

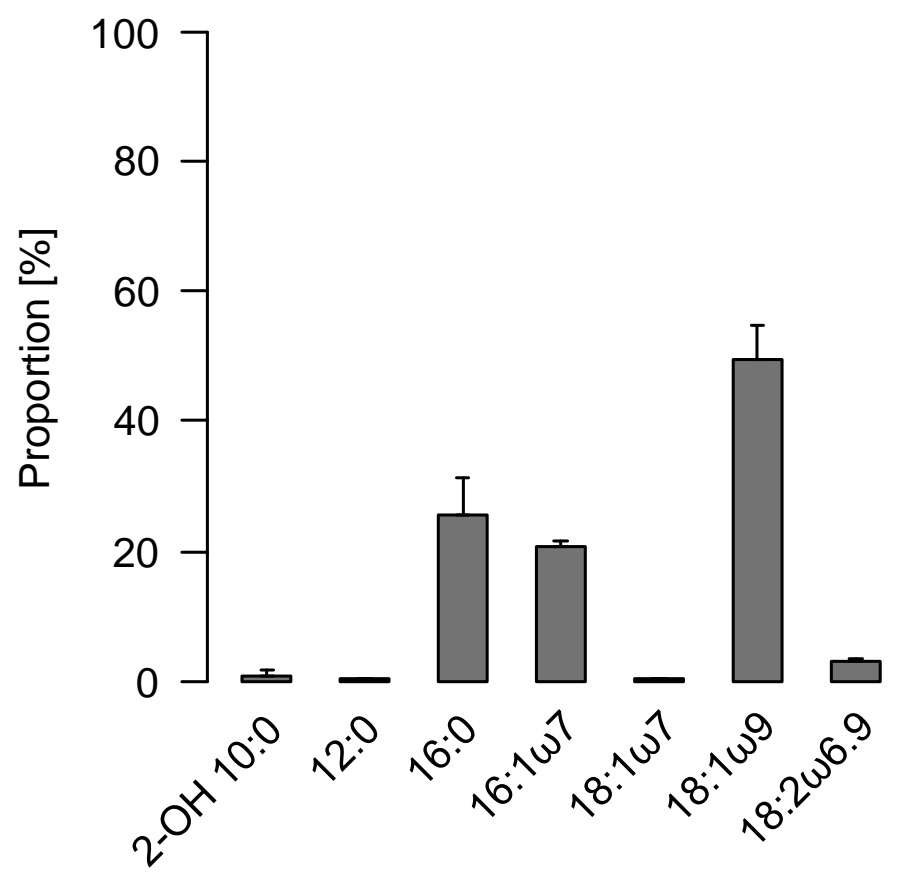

Fig. 5.1: Percentages of neutral lipid fatty acids in Acerentomon sp. (of total FAs; means \pm SD).

In the labeling experiment Acerentomon sp. was highly enriched in ${ }^{13} \mathrm{C}$ under beech, but only slight enriched in ${ }^{15} \mathrm{~N}$ indicating that they fed on ectomycorrhizal hyphae as plant $\mathrm{C}$, but not plant $\mathrm{N}$ is transferred into mycorrhizal fungi. In fact, ectomycorrhizal root tips with ECM were little enriched in ${ }^{15} \mathrm{~N}$ whereas root parts the tip were strongly enriched (ranging from $0.01-0.06$ and $0.02-0.1$ APE [\%], respectively; S. Ammerschubert, unpubl. data), which is in line with the 
functioning of ectomycorrhiza in capturing soil $\mathrm{N}$ and transferring it to plant roots (Smith \& Read 1997). Overall, the results support the increasing evidence that Protura strongly rely on rootderived resources (Krauss \& Funke 1999; Malmström \& Persson 2011) and are specialized in sucking up the cytoplasm of mycorrhizal hyphae (Sturm 1959; Pass \& Szucsich 2011; Ekblad et al. 2013).

Interestingly, our results suggest that body $\mathrm{C}$ and $\mathrm{N}$ of Acerentomon sp. are of different origin. While $C$ is derived from freshly assimilated plant $C$ transported from leaves to roots and into mycorrhiza, $\mathrm{N}$ is derived from soil via inorganic and organic $\mathrm{N}$ compounds derived from decomposing soil organic matter assimilated by ectomycorrhizal fungal hyphae and transported to plant roots (Read \& Perez-Moreno 2003). This contrasts other soil invertebrates which gain both root $\mathrm{C}$ and $\mathrm{N}$ for tissue formation (S. Zieger, unpubl. data).

Compared to beech Acerentomon sp. was less enriched in ${ }^{13} \mathrm{C}$ in the ash rhizosphere indicating that Acerentomon sp. feeds little on arbuscular mycorrhizal fungi associated with ash. Presumably, Protura switch diet and feed on saprotrophic fungi if ectomycorrhizal fungi are scarce as suggested earlier (Sturm 1959). However, as indicated by low abundance of Acerentomon sp. in ash as compared to beech rhizosphere they suffered from food shortage resulting in reduced density. The high ${ }^{15} \mathrm{~N}$ natural abundance signature of Acerentomon sp. supports our conclusion that it predominantly feeds on ectomycorrhizal fungi as the mycorrhizal fungal sheath of root tips is enriched in ${ }^{15} \mathrm{~N}$ (Högberg et al. 1996). Little feeding on arbuscular mycorrhizal fungi by Acerentomon sp. likely is related to the small hyphal diameter of arbuscular as compared to ectomycorrhizal fungi (Smith \& Read 1997), suggesting that it prevents effective sucking of hyphal cytoplasm.

High incorporation of NLFAs $16: 0$ and $18: 1 \omega 9$ as found in Acerentomon also has been reported from other fungal feeding animals such as the Collembola species Protaphorura firmata feeding on the fungus Agrocybe gibberosa (Haubert et al. 2004). In contrast to fungal feeding Collembola

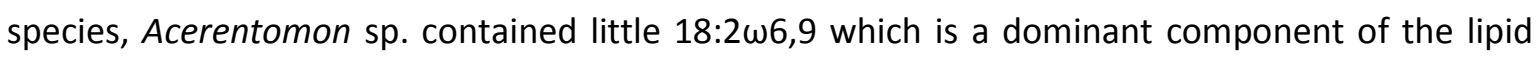
membrane of fungi and is commonly used as fungal biomarker (Ruess et al. 2002). This supports our conclusion and earlier observations (see above) that in contrast to fungal feeding Collembola Acerentomon sp. sucks up the cytoplasm of mycorrhizal hyphae. 


\section{Acknowledgments}

This project was funded by the German Research Foundation (GRK1086/2, project A04). We are grateful to Prof. Dr. C. Ammer for study site advice. We thank Tobias Lauermann, Silke Ammerschubert and Janine Sommer for help excavating trees from the forest. Bernd Kopka, Thomas Klein from the Labor für Radioisotope (LARI, University of Göttingen) for technical advice and help in using the plant growth chamber and the Kompetenzzentrum Stabile Isotope (KOSI, University of Göttingen) for measuring stable isotopes.

\section{References}

Díaz-Aguilar, I. \& Quideau, S.A. (2013) Trophic ecology of mesostigmatan and oribatid mites in harvested and control coniferous and deciduous stands of the boreal mixedwood forest determined using $15 \mathrm{~N}$ stable isotopes. Soil Biology \& Biochemistry, 67, 147-154.

Ekblad, A., Wallander, H., Godbold, D.L., Cruz, C., Johnson, D., Baldrian, P., Björk, R.G., Epron, D., Kieliszewska-Rokicka, B., Kjøller, R., Kraigher, H., Matzner, E., Neumann, J. \& Plassard, C. (2013) The production and turnover of extramatrical mycelium of ectomycorrhizal fungi in forest soils: role in carbon cycling. Plant and Soil, 366, 1-27.

Ferlian, O. \& Scheu, S. (2013) Shifts in trophic interactions with forest type in soil generalist predators as indicated by complementary analyses of fatty acids and stable isotopes. Oikos, 123, 1182-1191.

Haubert, D., Häggblom, M.M., Scheu, S. \& Ruess, L.R. (2004) Effects of fungal food quality and starvation on the fatty acid composition of Protaphorura fimata (Collembola). Comparative biochemistry and physiology. Part B, Biochemistry \& molecular biology, 138, 41-52.

Högberg, P., Högbom, L., Schinkel, H., Högberg, M., Johannisson, C. \& Wallmark, H. (1996) 15N abundance of surface soils, roots and mycorrhizas in profiles of European forest soils. Oecologia, 108, 207-214.

Krauss, J. \& Funke, W. (1999) Extraordinary high density of Protura in a windfall area of young spruce plants. Pedobiologia, 43, 44-46.

Langel, R. \& Dyckmans, J. (2014) Combined (13) C and (15) N isotope analysis on small samples using a near-conventional elemental analyzer/isotope ratio mass spectrometer setup. Rapid Communications in Mass Spectrometry, 28, 1019-1022.

Malmström, A. \& Persson, T. (2011) Responses of Collembola and Protura to tree girdling - some support for ectomycorrhizal feeding. Soil Organisms, 83, 279-285.

Pass, G. \& Szucsich, N.U. (2011) 100 years of research on the Protura: many secrets still retained. Soil Organisms, 83, 309-334.

Read, D.J. \& Perez-Moreno, J. (2003) Mycorrhizas and nutrient cycling in ecosystems - a journey towards relevance? New Phytologist, 157, 475-492.

Ruess, L.R., Häggblom, M.M., Zapata, E.J.G. \& Dighton, J. (2002) Fatty acids of fungi and nematodes - possible biomarkers in the soil food chain? Soil Biology \& Biochemistry, 34, 745756.

Schaefer, M. \& Schauermann, J. (1990) The soil fauna of beech forests: comparison between a mull and a moder soil. Pedobiologia, 34, 299-314.

Schneider, K. \& Maraun, M. (2009) Top-down control of soil microarthropods - Evidence from a laboratory experiment. Soil Biology \& Biochemistry, 41, 170-175. 
Smith, S.E. \& Read, D.J. (1997) Mycorrhizal Symbiosis, Second Edi. Elsevier.

Sturm, H. (1959) Die Nahrung der Proturen. Die Naturwissenschaften, 46, 90-91. 


\section{Chapter 6}

\section{General Discussion}

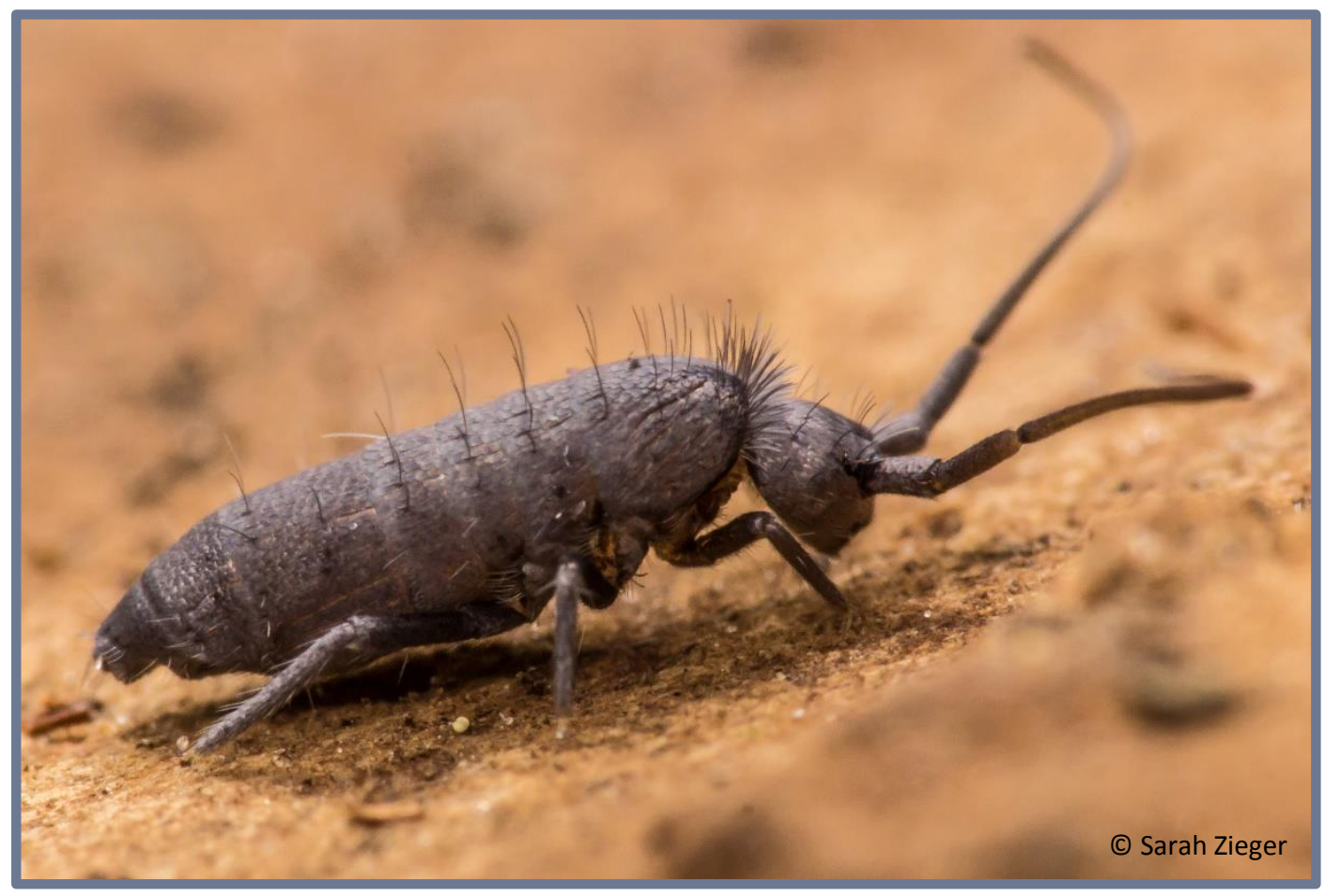




\section{Leaf litter-and root pathway}

By using stable isotope enrichment experiments, this thesis investigated the contribution of leaf litter- and root-derived resources for fueling soil animal food webs. The first study (Chapter 2) investigated the contribution of litter-derived resources to soil animal nutrition, while the second, third and fourth study (Chapter 3 - 5) investigated the contribution of root-derived resources.

In the first study (Chapter 2), results show that soil mites of all trophic levels including primary and secondary decomposers as well as predators at least to some degree relied on leaf litterderived resources. However, the contribution was generally low which is in line with Caner et al. (2004), who analyzed the contribution of litter-derived $\mathrm{N}$ to soil animal nutrition. By analyzing both, $\mathrm{C}$ and $\mathrm{N}$ we could show that litter-derived $\mathrm{C}$ and $\mathrm{N}$ are simultaneously incorporated into soil mites. The low contribution of litter-derived resources to the nutrition of primary decomposers might be due to the fact that litter heavily attacked by fungi is preferred as food whereas recently fallen litter, as used in our study, is largely avoided (Rihani et al. 1995). Indeed it has been assumed that older litter from before the recent two growing seasons are incorporated by soil animals (Albers et al. 2006). In contrast, after three years of litter decomposition Pollierer et al. (2007) found only few animals relying on litter resources.

The low contribution of leaf litter-derived resources to soil mite nutrition reinforces the recent view that these resources are less important than root-derived resources (Ruf et al. 2006; Pollierer et al. 2007). Indeed, results of Chapter 3 and 4 showed that root-derived $C$ was incorporated into soil animals of all trophic levels. This is in line with previous studies investigating the incorporation of root-derived resources into soil animals in agroecosystems and grasslands (Garrett et al. 2001; Coleman et al. 2002; Bradford et al. 2012), pastures and forest ecosystems (Strickland et al. 2012; Eissfeller et al. 2013a; Gilbert et al. 2014). However, by direct comparison of root- versus litterderived resources in an agroecosystem contradicting results were found. Elfstrand et al. (2008) found leaf litter $C$ to be more important than root-derived $C$, but a contrasting pattern was found by Scheunemann et al. (2015). Presumably, plant species traits play an important role in the strength of root and litter energy fluxes into soil animal food webs.

In contrast to previous studies, in this thesis both root-derived $\mathrm{C}$ and $\mathrm{N}$ were investigated by exposing plant shoots to ${ }^{13} \mathrm{CO}_{2}$ enriched atmosphere and immersing plant leaves in $\mathrm{Ca}^{15} \mathrm{NO}_{3}$ (Chapter 3) and ${ }^{15} \mathrm{NH}_{4} \mathrm{Cl}$ solution (Chapter $4+5$ ). The results show for the first time that in addition to $\mathrm{C}$ also root-derived $\mathrm{N}$ is incorporated into the soil animal food web. It has been reported previously that plant leaves absorb gaseous nitrate or ammonium solutions and assimilate the ${ }^{15} \mathrm{~N}$ into amino acids (Hutchinson et al. 1972; Porter et al. 1972; Ito \& Kumazawa 1976). The transport towards roots has been assumed to play an important role in building up new tissue of young roots (Oghoghorie \& Pate 1972; Tatsumi \& Kono 1981). Further, it is known that root exudates contain 
amino acids, thereby it is very likely that plant leaf assimilated $\mathrm{N}$ is transferred via rhizodeposits into the soil. Via soil microorganisms root-derived $\mathrm{N}$ is then propagated into microbivorous soil animals. Even though the amount of $\mathrm{N}$ transferred within the plant from roots to the shoot exceeds that from the shoot towards the roots manifold, the latter might have important ecological consequences. By releasing amino acids plant roots could stimulate microbes thereby affecting nutrient availability in soil animal food webs. Applying ${ }^{15} \mathrm{~N}$ to leaves for labeling plants is controversially discussed (Gasser et al. 2015) as a flush of nitrogen is applied to leaves that does not occur under natural conditions. Nevertheless, this labeling method is the most suitable and is widely used to estimate $\mathrm{N}$ fluxes (Wichern et al. 2008).

Chapter 2 and 4 revealed that energy fluxes from litter and roots into soil animals are species specific and independent of trophic levels. In Chapter 2 the incorporation of litter-derived resources was significantly different in the two secondary decomposers Damaeus riparius and Nothrus silvestris as well as in the predators Veigaia nemorensis and Uroseius cylindricus. In Chapter 4 the predator V. nemorensis incorporated significantly more root-derived C than U. cylindricus, Uropoda cassidea and Trachytes aegrota. Likewise in the two primary decomposers Steganacarus magnus and $N$. palustris the incorporation of root-derived $\mathrm{C}$ and $\mathrm{N}$ significantly differed. This reinforces the importance to investigate soil animals on a high taxonomic resolution rather than on wide taxonomic units or trophic groups.

Species also differentially incorporated litter- and root-derived resources. The predacious mite U. cylindricus incorporated less litter-derived $\mathrm{C}$ and $\mathrm{N}$ (Chapter 2 ) indicating that this species relies on other resources, such as older leaf litter or root-derived resources. However, the contribution of root-derived resources was also low which could originate from slow metabolic turnover resulting in minor changes of body tissue in a short term labeling experiment such as in the study of Chapter 4 which lasted for 20 days. To clarify the contribution of litter- and root-derived resources experiments with both pathways labeled are needed. A second predacious mite $V$. nemorensis incorporated intermediate amounts of leaf litter $\mathrm{C}$ and $\mathrm{N}$ (Chapter 2 ) and high amounts of root-derived resources (Chapter 4), indicating that their prey mainly rely on root-derived resources and to a lesser extent also on litter-derived resources. The primary decomposer $S$. magnus incorporated high amounts of litter-derived resources and was intermediately enriched in ${ }^{13} \mathrm{C}$ and ${ }^{15} \mathrm{~N}$ in the root labeling experiment, indicating that even primary decomposers rely on rootderived resources possibly mediated by fungal mycelia, which is in line with findings of Pollierer et al. (2007) 


\section{Tree species identity}

Results of this thesis indicate that energy fluxes from leaf litter to the belowground soil animal food web differ between European beech (Fagus sylvatica) and common ash (Fraxinus excelsior). These two species differ in physiological and ecological traits such as leaf litter quality and type of mycorrhizal association. In the study of Chapter 2, which investigated the contribution of litterderived $\mathrm{C}$ and $\mathrm{N}$ to soil mite nutrition, displayed a higher incorporation of $\mathrm{C}$ and $\mathrm{N}$ from ash than from beech leaf litter into soil mites suggesting that soil animal food webs benefit from leaf litter low in structural compounds. This was reflected by the preference for litter low in structural compounds at least in one species, Platynothrus peltifer. Tensile strength and palatability might be reasons for the preference (Anderson 1973; Perez-Harguindeguy et al. 2000). In contrast, soil animals incorporated more root-derived resources ( $\mathrm{C}$ and $\mathrm{N}$ ) in the beech rhizosphere compared to the ash rhizosphere (Chapter 4). This might be related to the different type of mycorrhiza of the analyzed tree species. Beech trees are associated with ectomycorrhizal fungi (EMF) while ash trees are associated with arbuscular mycorrhizal fungi (AMF). In previous studies the intensity of the rhizosphere effect has been assumed to be related to ECM (Phillips \& Fahey 2005, 2006). The results indicate that the energy flux in the food web of beech differs from that of ash. Beech trees produce leaf litter which is difficult to ingest, but root-derived resources released into the rhizosphere are intensively incorporated into the soil animal food web. In contrast, ash produces high quality leaf litter which is quickly fed and incorporated by detritivores, but the incorporation of root-derived resources into soil invertebrates is less pronounced as compared to beech.

In the field experiment (Chapter 3 ) soil animals incorporated root-derived $C$ in the ash rhizosphere, but not in the beech rhizosphere, which contrasts results of the study in Chapter 4 . This study was conducted in plant growth chamber and results show that both $\mathrm{C}$ and $\mathrm{N}$ were more incorporated into soil animals in the beech compared to the ash rhizosphere. The reason for the difference might be the fact that the experiment in Chapter 3 took place in the shaded understory of a mature beech forest and therefore the investigated trees might have been light limited. As ash trees have a higher photosynthetic efficiency they possibly benefited by a larger ${ }^{13} \mathrm{CO}_{2}$ uptake during the relative short labeling period of five hours. In the plant growth chamber experiment of Chapter 4 young trees were exposed to ${ }^{13} \mathrm{CO}_{2}$ under controlled conditions with light intensities being ideal for plant growth. The pronounced difference in energy fluxes into soil animals of the two analyzed tree species contrasted results of Eissfeller et al. (2013a). Her labeling experiment lasted for five months and no difference between trees in the incorporation of resources into soil animals in the beech and ash rhizosphere were found. This indicates that in the long-term the low flux of rootderived resources from ash into the soil animal food web is compensated for by the provisioning of other root-derived resources, potentially dead roots. 


\section{Stability}

As Pollierer et al. $(2007,2009)$ already stated, soil food webs are not compartmentalized in an absolute manner, rather the leaf litter and root pathway contribute to differential amounts to the nutrition of soil animals. As indicated by these earlier studies, the contribution of these two pathways to soil animal nutrition varies between species, but also depends on resource availability and quality, and therefore likely changes with development stage of plants and soil animals. Incorporation of both litter- and root-derived resources might function as insurance of soil animal species against food shortage from one pathway, e.g. complete decomposition of ash litter before the next seasonal litter fall. This leads to an interlinked food web allowing switches of resource use thereby fostering food web stability (Rooney et al. 2006; Pollierer et al. 2012).

Conform to this view, results of the present study showed that soil mites exhibit trophic plasticity and switched diet from litter low in structural compounds that almost decomposed after 10 months to those high in structural compounds later in the experiment (Chapter 2). Fast decomposition of ash litter results in deprivation of food and habitat, and indeed it has been shown that under ash trees Oribatida are less abundant than under beech trees (Eissfeller et al. 2013b). The trophic plasticity of soil animals is also reflected in the large difference between the incorporation of root-derived resources in the rhizosphere of beech and ash, e.g., Onychiuridae and Acerentomon sp. incorporated high amounts of root-derived $\mathrm{C}$ in the rhizosphere of beech, but not in that of ash (Chapter 4 and 5).

\section{Outlook}

Overall, the results of this thesis support the view that incorporation of litter resources into the soil animal food web is low. However, the low contribution of leaf litter-derived resources to the nutrition of primary decomposers might be compensated by the incorporation of older litter resources. Therefore, it would be interesting to investigate the contribution of litter-derived resources in the course of several years especially in later decomposition stages when $\mathrm{C}$ and $\mathrm{N}$ is stabilized as soil organic matter.

Further, there is the need to unravel energy fluxes in food webs by combining investigations of energy pathways (litter and root pathway) with energy channels (bacteria, fungi and plants). Based on earlier studies it has been assumed that the litter pathway is dominated by fungi, while the root pathway is dominated by bacteria energy channels (Moore et al. 2004; Wardle et al. 2004). In contrast to this view there is increasing evidence in recent years that also root-derived resources are quickly incorporated into fungi (Lemanski \& Scheu 2014a; Pausch et al. 2015). Combining labeling experiments with fatty acid analysis allows differentiating energy pathways and channels. By adopting these methods using compound specific amino acid analysis the contribution of both, $\mathrm{C}$ and $\mathrm{N}$ can be analyzed. Further, identification of the basal resource is needed to allow comparison 
of soil animal communities of different ecosystems which is difficult to achieve by using stable isotope analysis. Novel techniques such as the analysis of natural variations in stable isotope signatures of amino acids are a promising tool as they allow identifying trophic positions without knowing stable isotope signatures of basal resources (Larsen et al. 2009).

Further, more detailed knowledge is needed on the exact feeding habits and distribution patterns of soil animals to understand their food relationships and functioning in decomposer communities. With the availability of new methods such as fatty acid analysis and DNA gut content analysis progress has been made, but understanding of trophic links and interactions in complex food webs still is limited. Combing the different methods available including DNA gut content analysis, stable isotope analysis and fatty acid and amino acid analysis is very promising and will contribute to a deeper understanding of the structure and functioning of decomposer food webs. In addition, there is the need of erecting databases combining information on the distribution and abundance of soil animal species with information on their traits and trophic interactions as presently developed (e.g., Edaphobase; http://portal.edaphobase.org). This developments and new techniques will allow major progress in long standing issues in soil ecology such as the structure of the soil animal food webs and their functioning in ecosystem element cycling. 


\section{References}

Albers, D., Schaefer, M. \& Scheu, S. (2006) Incorporation of plant carbon into the soil animal food web of an arable system. Ecology, 87, 235-245.

Anderson, J.M. (1973) The breakdown and decomposition of sweet chestnut (Castanea sativa Mill.) and beech (Fagus sylvatica L.) leaf litter in two deciduous woodland soils. Oecologia, 12, 251274.

Bradford, M.A., Strickland, M.S., DeVore, J.L. \& Maerz, J.C. (2012) Root carbon flow from an invasive plant to belowground foodwebs. Plant and Soil, 359, 233-244.

Caner, L., Zeller, B., Dambrine, E., Ponge, J.-F., Chauvat, M. \& Llanque, C. (2004) Origin of the nitrogen assimilated by soil fauna living in decomposing beech litter. Soil Biology \& Biochemistry, 36, 1861-1872.

Coleman, D.C., Fu, S., Hendrix, P. \& Crossley, D. (2002) Soil foodwebs in agroecosystems: Impacts of herbivory and tillage management. European Journal of Soil Biology, 38, 21-28.

Eissfeller, V., Beyer, F., Valtanen, K., Hertel, D., Maraun, M., Polle, A. \& Scheu, S. (2013a) Incorporation of plant carbon and microbial nitrogen into the rhizosphere food web of beech and ash. Soil Biology \& Biochemistry, 62, 76-81.

Eissfeller, V., Langenbruch, C., Jacob, A., Maraun, M. \& Scheu, S. (2013b) Tree identity surpasses tree diversity in affecting the community structure of oribatid mites (Oribatida) of deciduous temperate forests. Soil Biology \& Biochemistry, 63, 154-162.

Elfstrand, S., Lagerlöf, J., Hedlund, K. \& Mårtensson, A. (2008) Carbon routes from decomposing plant residues and living roots into soil food webs assessed with $13 \mathrm{C}$ labelling. Soil Biology \& Biochemistry, 40, 2530-2539.

Garrett, C.J., Jr, D.A.C., Coleman, D.C., Hendrix, P.F., Kisselle, K.W. \& Potter, R.L. (2001) Impact of the rhizosphere on soil microarthropods in agroecosystems on the Georgia piedmont. Applied Soil Ecology, 16, 141-148.

Gasser, M., Hammelehle, A., Oberson, A., Frossard, E. \& Mayer, J. (2015) Quantitative evidence of overestimated rhizodeposition using $15 \mathrm{~N}$ leaf-labelling. Soil Biology and Biochemistry, 85, 10 20.

Gilbert, K.J., Fahey, T.J., Maerz, J.C., Sherman, R.E., Bohlen, P., Dombroskie, J.J., Groffman, P.M. \& Yavitt, J.B. (2014) Exploring carbon flow through the root channel in a temperate forest soil food web. Soil Biology \& Biochemistry, 76, 45-52.

Hutchinson, G.L., Millington, R.J. \& Peters, D.B. (1972) Atmospheric ammonia: absorption by plant leaves. Science (New York, N.Y.), 175, 771-772.

Ito, O. \& Kumazawa, K. (1976) Nitrogen assimilation in sunflower leaves and upward and downward transport of nitrogen. Soil Science and Plant Nutrition, 22, 181-189.

Larsen, T., Taylor, D.L., Leigh, M.B. \& O'Brien, D.M. (2009) Stable isotope fingerprinting: a novel method for identifying plant, fungal, or bacterial origins of amino acids. Ecology, 90, 35263535.

Lemanski, K. \& Scheu, S. (2014) Incorporation of 13 C labelled glucose into soil microorganisms of grassland: Effects of fertilizer addition and plant functional group composition. Soil Biology and Biochemistry, 69, 38-45. 
Moore, J.C., Berlow, E.L., Coleman, D.C., Ruiter, P.C., Dong, Q., Hastings, A., Johnson, N.C., McCann, K.S., Melville, K., Morin, P.J., Nadelhoffer, K.J., Rosemond, A.D., Post, D.M., Sabo, J.L., Scow, K.M., Vanni, M.J. \& Wall, D.H. (2004) Detritus, trophic dynamics and biodiversity. Ecology Letters, 7, 584-600.

Oghoghorie, C.G. \& Pate, J.S. (1972) Exploration of the nitrogen transport system of a nodulated legume using (15)N. Planta, 104, 35-49.

Pausch, J., Kramer, S., Scharroba, A., Scheunemann, N., Butenschoen, O., Kandeler, E., Marhan, S., Riederer, M., Scheu, S., Kuzyakov, Y. \& Ruess, L. (2015) Small but active - pool size does not matter for carbon incorporation in below-ground food webs. Functional Ecology, in press.

Perez-Harguindeguy, N., Diaz, S., Cornelissen, J.H.C., Vendramini, F., Cabido, M. \& Castellanos, A. (2000) Chemistry and toughness predict leaf litter decomposition rates over a wide spectrum of functional types and taxa in central Argentina. Plant and Soil, 218, 21-30.

Phillips, R.P. \& Fahey, T.J. (2005) Patterns of rhizosphere carbon flux in sugar maple (Acer saccharum) and yellow birch (Betula allegheniensis) saplings. Global Change Biology, 11, 983995.

Phillips, R.P. \& Fahey, T.J. (2006) Tree species and mycorrhizal associations influence the magnitude of rhizosphere effects. Ecology, 87, 1302-1313.

Pollierer, M.M., Dyckmans, J., Scheu, S. \& Haubert, D. (2012) Carbon flux through fungi and bacteria into the forest soil animal food web as indicated by compound-specific $13 \mathrm{C}$ fatty acid analysis. Functional Ecology, 26, 978-990.

Pollierer, M.M., Langel, R., Körner, C., Maraun, M. \& Scheu, S. (2007) The underestimated importance of belowground carbon input for forest soil animal food webs. Ecology Letters, 10, 729-736.

Pollierer, M.M., Langel, R., Scheu, S. \& Maraun, M. (2009) Compartmentalization of the soil animal food web as indicated by dual analysis of stable isotope ratios (15N/14N and 13C/12C). Soil Biology \& Biochemistry, 41, 1221-1226.

Porter, L.K., Viets, F.G. \& Hutchinson, G.L. (1972) Air containing nitrogen-15 ammonia: foliar absorption by corn seedlings. Science (New York, N.Y.), 175, 759-761.

Rihani, M., Cancela da Fonseca, J.P. \& Kiffer, E. (1995) Decomposition of beech leaf litter by microflora and mesofauna. II. Food preferences and action of oribatid mites on different substrates. European Journal of Soil Biology, 31, 67-79.

Rooney, N., McCann, K., Gellner, G. \& Moore, J.C. (2006) Structural asymmetry and the stability of diverse food webs. Nature, 442, 265-269.

Ruf, A., Kuzyakov, Y. \& Lopatovskaya, O. (2006) Carbon fluxes in soil food webs of increasing complexity revealed by $14 \mathrm{C}$ labelling and $13 \mathrm{C}$ natural abundance. Soil Biology \& Biochemistry, 38, 2390-2400.

Scheunemann, N., Digel, C., Scheu, S. \& Butenschoen, O. (2015) Roots rather than shoot residues drive soil arthropod communities of arable fields. Oecologia, 179, 1135-1145.

Strickland, M.S., Wickings, K. \& Bradford, M.A. (2012) The fate of glucose, a low molecular weight compound of root exudates, in the belowground foodweb of forests and pastures. Soil Biology \& Biochemistry, 49, 23-29.

Tatsumi, J. \& Kono, Y. (1981) Translocation of foliar-applied nitrogen to rice roots. Japanese journal of crop science, 50, 302-310. 
Wardle, D.A., Bardgett, R.D., Klironomos, J.N., Setälä, H., van der Putten, W.H. \& Wall, D.H. (2004) Ecological linkages between aboveground and belowground biota. Science, 304, 1629-1633.

Wichern, F., Eberhardt, E., Mayer, J., Joergensen, R.G. \& Müller, T. (2008) Nitrogen rhizodeposition in agricultural crops: Methods, estimates and future prospects. Soil Biology \& Biochemistry, 40, 30-48. 


\section{DANKSAGUNG}

... Meinem Doktorvater, Prof. Dr. Stefan Scheu, möchte ich sehr für die hervorragende Betreuung meiner Doktorarbeit danken.

... Prof. Dr. Mark Maraun danke ich für seine Anregungen und fruchtbare Diskussionen.

... Den MitarbeiterInnen Christel Fischer, Andrea Lambertz, Susanne Böning-Klein, Ingrid Kleinhans, Elisabeth Opielka, Guido Humpert, Dieter Nünchert und Bernd Messerschmidt danke ich für die großartige Unterstützung in technischen und bürokratischen Belangen.

... Auch der ganzen AG möchte ich für die vielseitige Unterstützung danken.

... Meiner Mutter Regina Zieger und meinem Vater Peter Zieger danke ich für die emotionale und finanzielle Unterstützung, sowie für das große Interesse an meiner Arbeit.

... In Dankbarkeit erinnere ich mich an meine verstorbene leibliche Mutter Marga Werkhoven, die als Biologin mit jener Begeisterung arbeitete, die ich auch für mich selbst entdecken konnte. Ebenfalls danke ich meinem leiblichem Vater Iwan Wijngaarde und seinem Interesse für die Pflanzenwelt.

... Christian Bluhm, mein Lebensgefährte, hat mich mit seiner ruhigen und humorvollen Art auch in schwierigen Zeiten immer aufmuntern und unterstützen können- danke dafür!

... Selbstverständlich gilt mein Dank auch meinen Freunden, die mir ihr Verständnis und ihre Zeit geschenkt haben.

Die beste Morgengymnastik für einen Forscher ist es, jeden Tag vor dem Frühstück eine Lieblingshypothese über Bord zu werfen (Konrad Lorenz) 


\section{List OF PUblications}

Zieger, S.L., Eissfeller, V., Maraun, M. \& Scheu, S. (2015) Incorporation of carbon and nitrogen from leaf litter differing in structural compounds into soil microarthropods of a deciduous forest. Pedobiologia, 58, 219-227.

\section{THESIS DECLARATIONS}

Declaration of the author's own contribution to manuscripts with multiple authors.

Chapters 2 comprise a manuscript that has been published in a peer-reviewed journal. In all manuscripts except that presented in Chapter $2 \mathrm{I}$ am the first author and I have collected and analyzed the data, written the manuscripts, developed the main ideas, created tables, figures and appendices and contributed significantly to the study design. To the study presented in Chapters 2 Verena Eissfeller and I have equally contributed to the manuscript. Verena Eissfeller has developed the study and we both collected the data and I analyzed the data and wrote the manuscript. All coauthors contributed to finalizing the manuscripts.

\section{Plagiarism declaration}

I declare that I have written this doctoral thesis independently. All persons contributing to the manuscripts have been named so. All sentences or passages quoted from other people's work have been specifically acknowledged by clear cross-referencing. I have not submitted this thesis in any form for another degree at any university or institution.

Sarah Lorain Janice Zieger

Göttingen, Dezember 2015 